San Jose State University

SJSU ScholarWorks

Master's Theses

Master's Theses and Graduate Research

Fall 2010

\title{
Inelastic Analysis of Steel Moment Resisting Frames in Light- Framed Wood Buildings
}

Matthew Knutsen

San Jose State University

Follow this and additional works at: https://scholarworks.sjsu.edu/etd_theses

\section{Recommended Citation}

Knutsen, Matthew, "Inelastic Analysis of Steel Moment Resisting Frames in Light-Framed Wood Buildings" (2010). Master's Theses. 3871.

DOI: https://doi.org/10.31979/etd.qqr7-bscq

https://scholarworks.sjsu.edu/etd_theses/3871

This Thesis is brought to you for free and open access by the Master's Theses and Graduate Research at SJSU ScholarWorks. It has been accepted for inclusion in Master's Theses by an authorized administrator of SJSU ScholarWorks. For more information, please contact scholarworks@sjsu.edu. 


\title{
INELASTIC ANALYSIS OF STEEL MOMENT RESISTING FRAMES IN LIGHT-FRAMED WOOD BUILDINGS
}

\author{
A Thesis \\ Presented to \\ The Faculty of the Department of Civil Engineering \\ San Jose State University \\ In Partial Fulfillment \\ of the Requirements for the Degree \\ Master of Science \\ by \\ Matthew D. Knutsen
}

December 2010 
(C) 2010

Matthew D. Knutsen

ALL RIGHTS RESERVED 
The Designated Thesis Committee Approves the Thesis Titled

INELASTIC ANALYSIS OF STEEL MOMENT RESISTING FRAMES IN LIGHT-FRAMED WOOD BUILDINGS

by

Matthew D. Knutsen

APPROVED FOR THE DEPARTMENT OF CIVIL ENGINEERING

SAN JOSE STATE UNIVERSITY

December 2010

Prof. Kurt McMullin, Ph.D., P.E. Department of Civil Engineering

Prof. Daniel Merrick, P.E. Department of Civil Engineering

Michael Keaster, S.E. Professional Engineer 


\title{
ABSTRACT \\ INELASTIC ANALYSIS OF STEEL MOMENT RESISTING FRAMES IN LIGHT-FRAMED WOOD BUILDINGS
}

\author{
by Matthew D. Knutsen
}

A preliminary quantitative analysis of steel moment resisting frames as the lateral force-resisting system for light-framed wood buildings was completed to identify issues requiring more advanced study. A two-story prototype building was evaluated. The lateral force-resisting system of the building contains intermediate steel moment frames with reduced beam section (RBS) connections, wood glulam collectors, and wood structural sheathing diaphragms. Building configuration and cross-sectional properties were assumed based on visual observation and typical design standards for local construction. A simplified pushover analysis and a traditional nonlinear pushover analysis were performed on the typical moment frame. It was determined that a total lateral load of 103 kips on the frame would cause first yielding of the RBS connections with the ultimate strength of the framing being 133 kips. This load was compared to the lateral loads expected to be generated by the seismic masses tributary to the various steel moment frames. An additional comparison was made with the collector design loads. It was determined that the largest tributary seismic mass in the building would be expected to cause the supporting frame to yield. Assuming that all collectors in the building were designed for the highest collector design load, the collectors also would have adequate capacity to transfer the lateral load required to yield the assumed IMF. 


\section{Table of Contents}

Chapter 1 - Introduction ...............................................................................................1

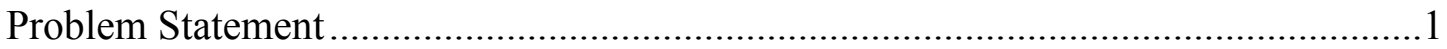

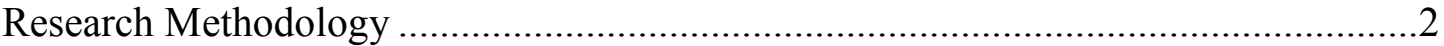

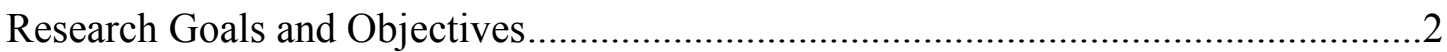

Chapter 2 - Literature Review ...............................................................................4

Review of Steel Moment Resisting Frames in Light-Framed Construction...................4

Review of Maximum Considered Earthquake Ground Motions .....................................4

ASCE 7-05 Design for Ductility ............................................................................6

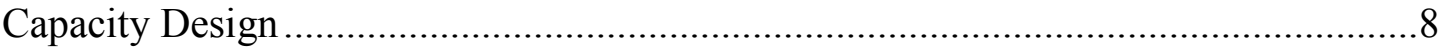

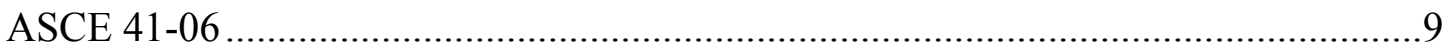

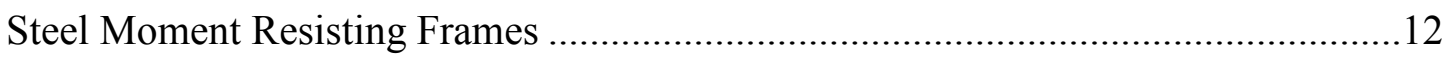

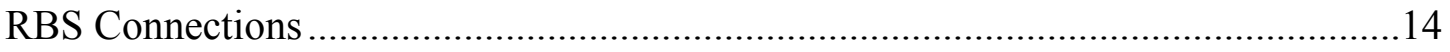

Chapter 3 - Building Design ............................................................................................18

Chapter 4 - Code Static Analysis ...............................................................................26

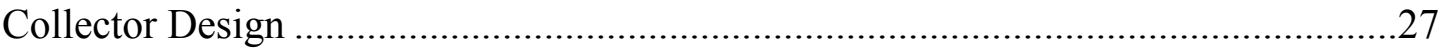

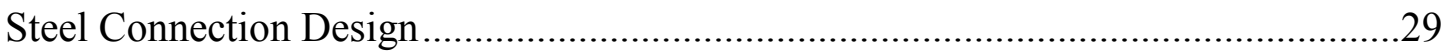

Chapter 5 - Linear and Nonlinear Frame Analysis .....................................................33

Analysis 1 ......................................................................................................

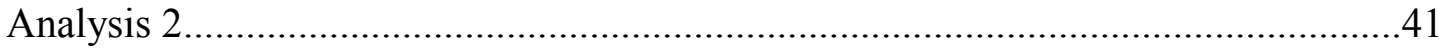

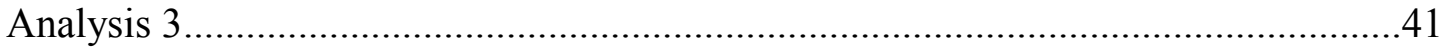

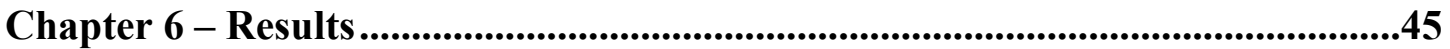

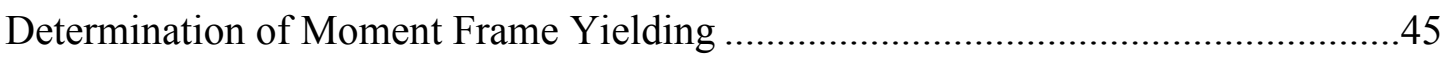

Collector Design Capacity ..................................................................................4

Chapter 7 - Conclusions and Recommendations.........................................................50

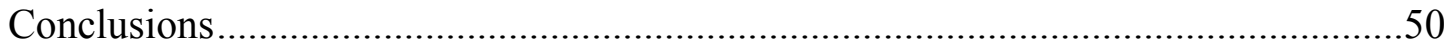

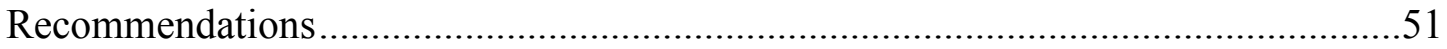

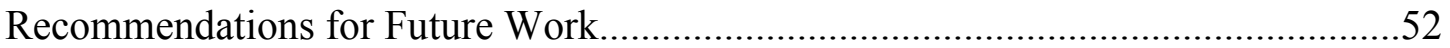

References.....................................................................................................................54

Appendix A - ASCE 7-05 Seismic Design Calculations ..............................................56 
Appendix B - RBS Design ......................................................................................60

Appendix $\mathrm{C}$ - Comparison of $\mathrm{M}_{\mathrm{DL}}$ to $\mathrm{M}_{\mathrm{pRBS}}$..........................................................65

Appendix D - Strong Column / Weak Beam Check ............................................68

Appendix E - RISA Model Output .........................................................................70

Appendix F - Simplified Design Frame Analysis.................................................86

Appendix G - Simplified Pushover Frame Analysis ...............................................89 


\section{$\underline{\text { List of Figures }}$}

Figure 2-1 - Normalized Hazard Curves for Selected Cities ........................................5

Figure 2-2 - Generalized Force-Deformation Relation ..............................................11

Figure 2-3 - Reduced Beam Section Connection ......................................................15

Figure 3-1 - Model Building Plans..................................................................19

Figure 3-2 - Building Moment Frame Layout.........................................................21

Figure 3-3 - Typical Moment Frame .....................................................................22

Figure 3-4 - Seismic Mass Tributary Area for N-S Earthquake .................................24

Figure 3-5 - Seismic Mass Tributary Area for E-W Earthquake …………………......24

Figure 4-1 - Seismic Mass Tributary to Collectors for N-S Earthquake......................27

Figure 4-2 - Seismic Mass Tributary to Collectors for E-W Earthquake.....................28

Figure 4-3 - Typical RBS Connection Detail .........................................................30

Figure 5-1 - Force-Controlled Plastic Mechanism Elastic Analysis .............................35

Figure 5-2 - RISA Model Frame ………………………….......................................

Figure 5-3 - RISA Frame Model with Floor Beam RBS Pinned ………………….......37

Figure 5-4 - RISA Frame Model with Roof Beam RBS Pinned ....................................38

Figure 5-5 - Analysis Results (Base Shear vs. Roof Deflection) ……………………...40

Figure 5-6 - ASCE 41-06 Generalized Moment-Rotation Curve for RBS Beam Hinge ..................................................................4

Figure 5-7 - SAP Nonlinear Pushover Model .............................................................44

Figure 6-1 - Frame Base Shear Comparison ............................................................46

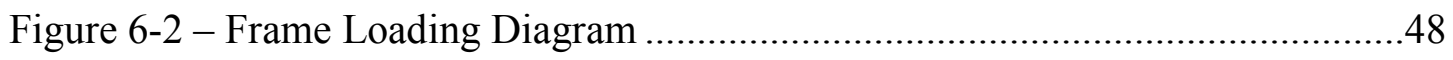




\section{List of Tables}

Table 3-1 - Tributary Area Dead Load and Live Load .............................................25

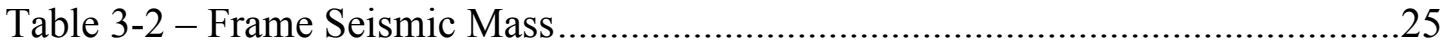

Table 4-1 - Frame Design Base Shear.......................................................................26

Table 4-2 - Overstrength Collector Design Load ...................................................29

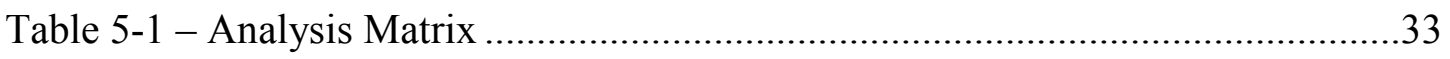

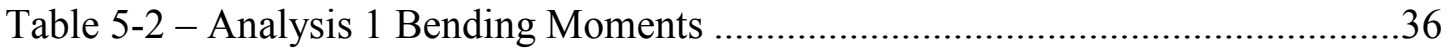

Table 5-3 - Design Base Shear to $\mathrm{V}_{\mathrm{p} \text {, frame }}$ Comparison ..........................................40

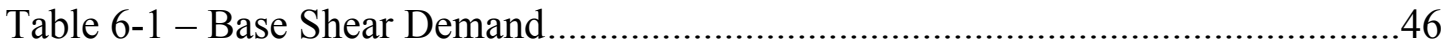

Table 6-2 - Collector Design Strength Comparison...............................................49 


\section{Chapter 1 - Introduction}

\section{$\underline{\text { Problem Statement }}$}

The use of steel moment resisting frames (MRF) as a lateral force resisting system in commercial buildings may be preferred by design engineers because the system does not require as many vertical members, diagonal braces, or sheathing, when compared to more traditional alternative lateral systems. Having more open space in the building walls allows for larger windows, entryways, garage openings, etc.

Engineers assume that moment resisting frames are highly deformable, remaining stable well into the inelastic region. These frames are intended to act as a ductile "fuse" in the system reducing the likelihood of a brittle failure.

However, considering the concept of Capacity Design, if there is another component in the system with a lower lateral load capacity, that weaker component will then become the weakest link in the load path. In the event of a major earthquake, it is expected that seismic accelerations may well produce internal forces up to the capacity of

the weakest link in the system. A potential concern with the MRF system of this study is that the wood collectors may not possess the strength to transfer inelastic-level forces from the diaphragm to the moment resisting frame. If this weak link component is not strong enough to transfer forces resulting from large inelastic deformations, then the ductility of the system may be significantly lower than expected. 


\section{$\underline{\text { Research Methodology }}$}

The research method used was the evaluation of a case study. A model building was selected to be the basis of this study. The lateral force-resisting system consisted of twelve two-story steel moment frames with Reduced Beam Section (RBS) connections. Code-based seismic loads were determined for the building based on the 2006 International Building Code (2006 IBC). A pushover analysis was performed on the typical two-story moment frame to determine the lateral force required to yield all of the RBS connections in the frame. The lateral force required to yield the steel moment frame was then compared to the design loads for the wood collectors.

\section{$\underline{\text { Research Goals and Objectives }}$}

The goal of this study was to evaluate the seismic behavior of steel frames in wood-framed commercial buildings. This preliminary evaluation was done to determine if a typical wood-frame building is likely to generate enough seismic load to cause steel moment resisting frames to undergo inelastic deformation and thus dissipate energy as steel moment frames are intended to behave during an earthquake. This inelastic behavior would be expected to help avoid a brittle failure of other non-ductile components in the system.

The objectives of this research were to:

- Conduct a literature review to gain better understanding about the use of steel MRF in wood-frame construction and portions of steel moment 
frame behavior, RBS connections, MCE ground motions, probabilistic seismic forces, and general seismic design principles related to the use of these frames;

- Define a prototype two-story wood framed building with steel MRF for lateral support;

- Determine the seismic design load for the prototype building based on assumed detailing requirements outlined in ASCE 7-05;

- Determine force demands for the collector system based upon the ASCE 7-05 design force;

- Detail the RBS connections at both the $2^{\text {nd }}$ floor and roof levels according to the requirements of AISC 358-05;

- Perform two force-controlled plastic mechanism frame analyses, one to verify adequate capacity in the frame to resist the design lateral forces, and one to gain better understanding of the global force-displacement relationships and corresponding collapse mechanisms;

- Perform a pushover analysis to define global force-displacement relationships and corresponding collapse mechanisms;

- Evaluate if any of the prototype building frames have enough tributary mass to cause formation of a collapse mechanism;

- Determine if the code designed collectors will have adequate strength to transfer the loads associated with the formation of a collapse mechanism in the steel moment frame. 


\section{Chapter 2 - Literature Review}

\section{$\underline{\text { Review of Steel Moment Resisting Frames in Light-Framed Construction }}$}

A document search was conducted to locate published research that discussed the use of steel moment frames in light-framed construction. An internet search was performed using Google and the key phrases "steel moment frames in wood construction," "steel moment frames in light framed construction," and "steel moment frames in wood buildings." A search for research documents and journal articles was performed using Compendex, which is an electronic database that can be accessed through the San Jose State University King Library. No research or information could be found regarding these topics.

\section{$\underline{\text { Review of Maximum Considered Earthquake Ground Motions }}$}

ASCE 7-05 design ground acceleration is based on a procedure that was originally introduced in the 1997 NEHRP Recommended Provisions for Seismic Regulations for New Buildings. This procedure uses spectral response accelerations that are obtained from maximum considered earthquake (MCE) ground motions (Leyendecker et al. 2000).

The MCE procedure was originally developed to provide uniformity in seismic design between various regions of the United States. Leyendecker et al. states that "MCE ground motions are uniformly defined as the maximum level of earthquake ground shaking that is considered as reasonable to design normal structures to resist." According to Leyendecker et al., this definition has helped to provide a uniform margin against collapse throughout the United States. 
The MCE procedure was needed because the variation in ground motion versus probability is not the same in various regions of the United States. For example, in Memphis the ground motion experienced during an earthquake with a $2 \%$ probability of exceedance in 50 years would be much higher than the ground motion experienced during an earthquake with a $10 \%$ probability of exceedance in 50 years, while in San Francisco the difference between ground motions of earthquakes of the same probability would be much less. Leyendecker et al. graphed spectral accelerations for a 0.2 second period in various cities of the United States versus their annual frequency of exceedance and then normalized the spectral accelerations for a $2 \%$ exceedance in 50 years [Figure 2$1]$.

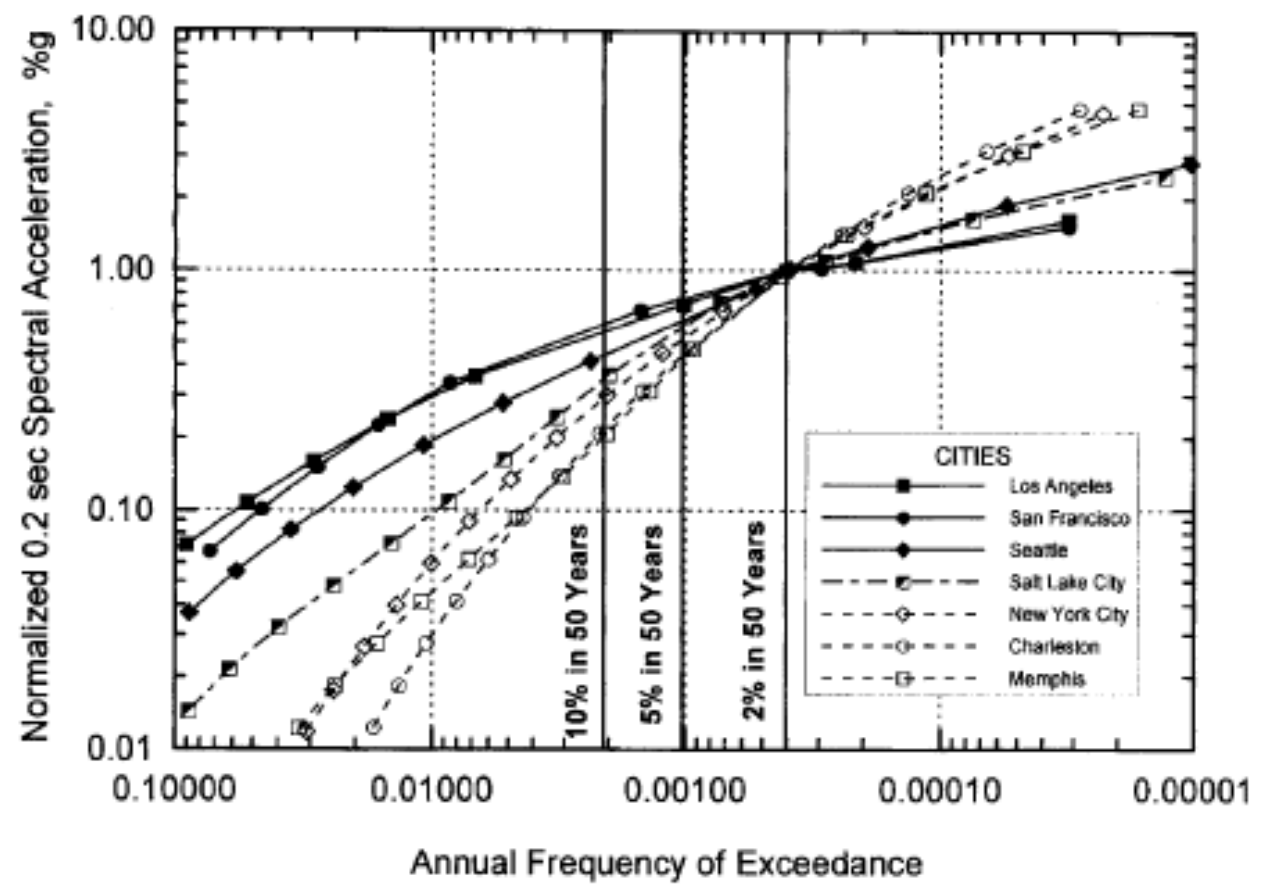

Figure 2-1 - Normalized Hazard Curves for Selected Cities (Reprinted with permission from EERI)

This graph shows that, once normalized for a $2 \%$ exceedance in 50 years, cities in the eastern United States would experience much higher spectral acceleration than western 
cities at frequencies of exceedance less than $2 \%$ in 50 years, while cities in the western United States would experience much higher spectral acceleration than eastern cities at frequencies of exceedance higher than $2 \%$ in 50 years. This means that if buildings in different regions were uniformly designed for seismic forces resulting from a $2 \%$

exceedance in 50 year earthquake, the buildings in the western United States would have greater reliability against collapse in earthquakes at frequencies of exceedance less than $2 \%$ in 50 years (Leyendecker et al. 2000).

Subsequently the MCE ground motion maps were developed for use in design by combining USGS seismic hazard maps according to a defined set of rules. The result was a set of design peak ground accelerations that provide a consistent margin against collapse in buildings across the United States. The one caveat with the MCE ground motions is that they are associated with collapse-level ground motions. To adjust the MCE ground motions to an appropriate design level, the acceleration values are divided by a factor of 1.5 (ASCE 7-05 uses multiplication by a factor of 2/3) which is considered the seismic margin against collapse (Leyendecker et al. 2000).

\section{ASCE 7-05 Design for Ductility}

ASCE 7-05 uses a response modification factor ( $\mathrm{R}$ factor) to account for the ductility of a specific lateral force resisting system being used in a building structure. The $\mathrm{R}$ factor reduces the linear elastic response spectrum of a structure to account for the lateral force resisting systems ability to dissipate energy by means of inelastic deformation (Riddell, 1989). Response modification factors have been listed for various 
lateral force resisting systems based on observed performance of structures supported by similar systems in past earthquakes (Uang, 1994). This reduction allows for a more economical design and the use of traditional engineering design and analysis practices.

Seismic design forces, as determined using ASCE 7-05, are based upon MCE ground motions. The basic ASCE 7-05 design earthquake force is two-thirds of the corresponding MCE force. These seismic forces are then reduced by the R factor specified for the lateral force resisting system used in the building and multiplied by the Importance factor (I) for the type of use. This modification to the MCE ground motion is reflected in the ASCE 7-05 Seismic Response Coefficient, $\mathrm{C}_{\mathrm{s}}$.

$$
C_{s}=\frac{S_{D S}}{\left(\frac{R}{I}\right)}
$$

where

$$
\mathrm{S}_{\mathrm{DS}}=\text { the design spectral response acceleration in the short period range }
$$

and $\quad S_{D S}=\frac{2}{3} S_{M S}$

where

$$
\mathrm{S}_{\mathrm{MS}}=\text { the MCE spectral response acceleration in the short period range }
$$

Thus the resulting design seismic force is related to the seismicity of a specific site but has been reduced to a suitable design level force to account for the inherent ductility of the lateral force resisting system.

If the lateral force resisting system is expected to be highly ductile, the $\mathrm{R}$ factor can be relatively high, such as 8 for a Special Moment Frame (ASCE 7-05 Table 12.2-1). The higher $\mathrm{R}$ factor results in a lower design load with correspondingly smaller structural 
components for the building, including all structural elements of the lateral system, i.e. collectors and diaphragm (Lindeburg \& McMullin, 2008).

By this same account a system with less ductility requires a higher capacity to resist lateral loads prior to allowing the system to yield, since the system does not have the ability to deform inelastically to reliably dissipate significant amounts of energy once the system exceeds the elastic state (Lindeburg \& McMullin, 2008). Therefore, less ductile lateral force resisting systems warrant a lower $\mathrm{R}$ factor requiring them to be designed for a higher seismic force.

\section{Capacity Design}

Two types of failure can occur in structures: brittle failure or ductile failure. A brittle failure occurs when little deformation, if any, occurs after the yield point. A brittle failure in a building structure is unfavorable as it allows for very little time to observe the failure and either repair it or evacuate the building. However, a ductile failure will see a much larger amount of deformation after the yield point and before a final ultimate failure and allows much more time to observe the failure and take appropriate action. In Capacity Design a ductile failure, called the Preferred Failure Mode, is identified and designed to minimize the chance of other brittle failure modes (McMullin, 2008).

Ductile seismic-resistant lateral systems can be based upon capacity design concepts. The assumption is that a pre-determined mode of failure, the Preferred Failure Mode, will occur first allowing for a controlled method of failure. Ductility of the system can then be provided by ensuring that the Preferred Failure Mode has adequate ductility. 
For a ductile system to behave as intended, the other elements in the lateral system must have the strength capacity to resist enough lateral force to cause the Preferred Failure Mode to occur first. This will require a larger margin of safety for the other elements in the system (McMullin, 2008). If the other elements in the system do not have the strength required to reach the load required for the Preferred Failure Mode a potential brittle failure mode could exist, thus greatly reducing the global ductility of the system.

\section{ASCE 41-06}

ASCE 41-06 Seismic Rehabilitation of Existing Buildings is a document developed from FEMA 356. ASCE 41-06 provides design guidelines for the rehabilitation of existing structures. ASCE 41-06 provides procedures for determining site-specific ground motions for two levels of earthquake hazard. The earthquake hazard levels determined are based on a probabilistic method. There are two common means of defining earthquake hazard. Probabilistic earthquake hazard levels are defined by probability of exceedance, meaning the probability that a more severe demand will be experienced in a given time period. Earthquake hazard levels are also often described in terms of Mean Return Period. The two earthquake hazard levels defined by ASCE 41-06 are; BSE-1 (Probability of Exceedance of 10\%/50 years, or Mean Return Period of 474 years) and BSE-2 (Probability of Exceedance of 2\%/50 years, or Mean Return Period of 2,475 years). 
The method provided by ASCE 41-06 for determining probabilistic earthquake hazard levels differs from the MCE design method used by ASCE 7-05 in that it defines earthquake hazard for an exact return period. An expected performance level is selected for the building and refers to the expected amount of damage incurred during an earthquake and the structural condition of the post-earthquake building. The building is then designed/retrofitted to meet the specific performance level for the hazard level at the exact return period being examined. For example, a building can be designed/retrofitted to meet a collapse prevention performance level in a $\% / 50$ year earthquake hazard (BSE-2) and an immediate occupancy performance level in a 10\%/50 year earthquake hazard (BSE-1). This gives a greater amount of control to the designer to tailor the performance of the building to meet the specific needs of the building owner.

ASCE 41-06 also describes a method for nonlinear static, or pushover, analysis of building structures. The method consists of the development of a mathematical model based on nonlinear load-deformation properties and then subjecting the model to monotonically increasing lateral loads until a predetermined displacement is reached (ASCE 41-06 3.3.3.1). Methods for determining the nonlinear properties and relationships are defined based on the type of material, i.e. steel, concrete, masonry, wood and light metal framing.

Section 5.4.2.2.2 of ASCE 41-06 defines a method for developing a generalized force-deformation relationship for use in nonlinear modeling. This method assumes a normalized standard force-deformation curve [Figure 2-2] for which exact parameters for specific components and actions are listed on Table 5-6 of ASCE 41-06. 


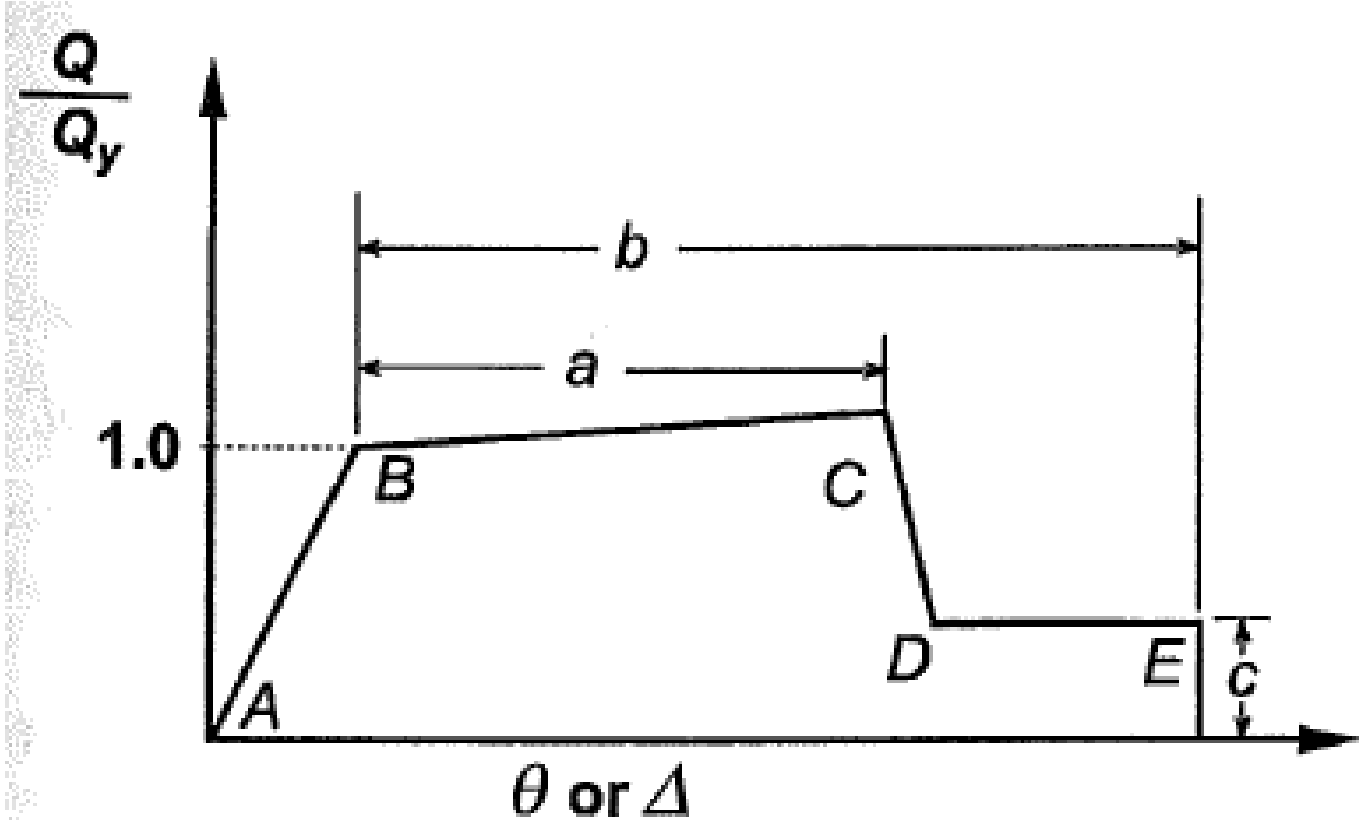

Figure 2-2 -ASCE 41-06 Figure 5-1 Generalized Force-Deformation Relation (Reprinted with permission from ASCE)

Point B on the curve is defined as the yield force or moment of the component. Point C on the curve is the point at which loss of strength occurs in the component and point $\mathrm{E}$ is the level of deformation where complete loss of load resisting ability occurs. The ASCE 41-06 document uses three parameters $(\mathrm{a}, \mathrm{b}$ and $\mathrm{c})$ to convert the normalized curve to engineering units. Parameter a is the range of component deformation for which nonlinear deformation occurs without loss of strength in the component. Parameter $b$ is the portion of the curve over which all nonlinear deformation occurs. The higher end range of $b$ coincides with Point E. Parameter $\mathrm{c}$ is the ratio of the expected force or moment level in the component during deformation occurring between points $\mathrm{D}$ and $\mathrm{E}$ and the peak level of resistance. 


\section{$\underline{\text { Steel Moment Resisting Frames }}$}

Steel moment resisting frames can withstand earthquake ground motion in one of two ways: elastically or inelastically. During a moderate to low seismic event a moment resisting frame (MRF) is expected to remain elastic. This allows the building to resist the lateral forces without suffering any permanent deformations. During a significant seismic event the moment resisting frame is expected to exceed the elastic limit and deform inelastically thus allowing for the dissipation of energy hysteretically. Once the MRF has become inelastic the lateral stiffness is reduced and, assuming that it is elastic perfectly plastic, the force being resisted by the MRF will not increase. If the MRF has not yielded, the lateral force resisted by the MRF will continue to increase if the ground acceleration continues to rise.

For this reason it is critical that the horizontal elements in the lateral system (diaphragm and collectors) possess the capacity to transmit the load required to yield the MRF. If the capacity of the horizontal elements transmitting the load to the MRF is less than the force required to yield the MRF, no dissipation of energy due to steel yielding can occur and the lateral force resisting system will be required to resist the full force developed by the ground acceleration rather than being limited to the capacity of the MRF.

A Special Moment Frame (SMF) design is assumed to contain adequate ductility in the beam-to-column connections if it satisfies the requirements of Section 9.2a of AISC 341-05. Section 9.2b states that the requirements of Section 9.2a may be satisfied by one of the following: 
(a) Use of SMF connections designed in accordance with ANSI/AISC 358.

(b) Use of a connection prequalified for SMF in accordance with Appendix $P$.

(c) Provision of qualifying cyclic test results in accordance with Appendix S. Results of at least two cyclic connection tests shall be provided and are permitted to be based on one of the following:

i) Tests reported in the research literature or documented tests performed for other projects that represent the project conditions, within the limits specified in Appendix $S$.

ii) Tests that are conducted specifically for the project and are representative of the project member sizes, material strengths, connection configurations, and matching connection processes, within the limits specified in Appendix $S$.

Intermediate Moment Frames (IMF) have less stringent ductility requirements than SMF but are still required to meet the ductility requirements set forth in AISC 34105 Section 10.2a, which modifies Section 9.2a for SMF. The requirements of AISC 34105 Section $10.2 \mathrm{a}$ can be satisfied in the same three ways as an SMF. The only exception is that connections must be prequalified for IMF instead of SMF (AISC 341-05 Section $10.2 b)$.

While AISC 341-05 defines a great amount of detail and requirements for the connections of a special moment resisting frames, limited guidance is given regarding the strength requirements of the elements delivering the seismic force to the moment frame. The only strength requirement for the elements delivering the seismic force would be the Overstrength Factor $\left(\Omega_{0}\right)$ which is prescribed by the building code. 


\section{$\underline{\text { RBS Connections }}$}

During the 1994 Northridge earthquake many welded-flange-bolted-web connections in steel moment resisting frames were damaged. Post-earthquake inspections revealed that $75 \%$ of the moment resisting frame buildings displayed cracks in the welds of the moment connections (Zarghamee, 1995). These damaged connections did not cause any building collapses or loss of life but the economic loss was catastrophic (Roeder, 2002). FEMA funded the SAC Steel Project whose main goal was to determine the causes for this damage and to find solutions.

Prior to the Northridge earthquake special moment resisting frames were perceived to be very ductile systems. The connection resistance was assumed to be larger than the resistance of the panel zone or the plastic moment capacity of the beam, so that the plastic rotation of the connection was expected to be high. Through the SAC Steel Project it was discovered that the major cause for the failure in the welded-flange-boltedweb connections was the inability of the connection to rotate inelastically. This inability to rotate inelastically would cause fracture in the beam or column, or fracture in the groove welds at the beam flange.

Due to the heavy failure of moment connections in steel frames the SAC Steel Project conducted research into developing alternative connections for steel moment resisting frames that could withstand the inelastic demands necessary for a steel moment connection. The Reduced Beam Section connection was examined as an alternative connection for these types of frames. 
Reduced Beam Section connections, or RBS connections, utilize beams that have a reduction in the cross-section of the beam allowing for a lower bending capacity in localized regions [Figure 2-3]. RBS connections have been shown to be very effective as ductile connections for steel moment resisting frames (Popov et al, 1998).

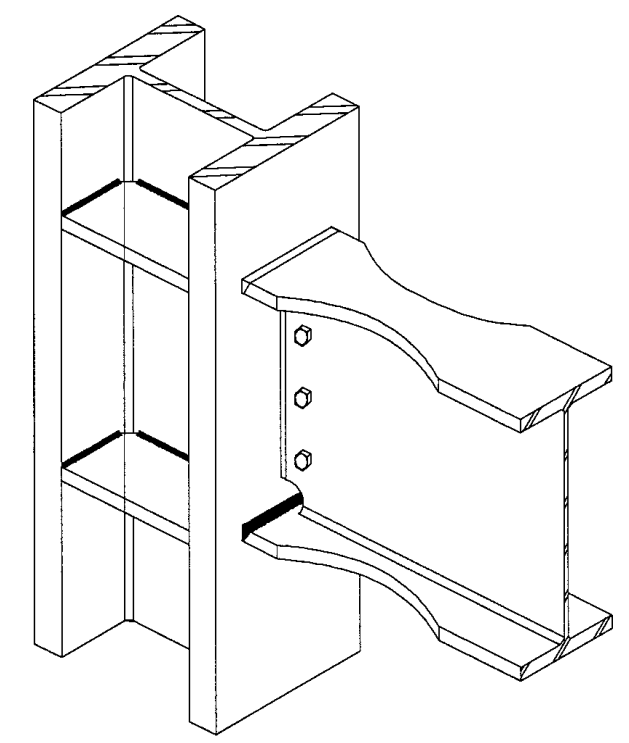

Figure 2-3 - Reduced Beam Section Connection (Reprinted with permission from ASCE)

The Reduced Beam Section (RBS) connection was developed to provide an inelastic hinge in the steel moment resisting frame beam-to-column subassembly. The RBS connection uses the philosophy of having a "fuse" in the system that has a known capacity and will deform inelastically at an appropriate load level. This will allow the connection to rotate inelastically without overloading critical components and causing a brittle fracture.

The concept of the Reduced Beam Section is not new to the field of structural engineering and was not invented as a result of the 1994 Northridge earthquake. The RBS, more commonly known as the "dogbone," was actually filed for patent by Arbed, a 
Luxembourg-based steel producer (Iwankiw \& Carter, 1996). After the heavy destruction to steel moment frame beam-to-column subassemblies in the Northridge earthquake (Popov, et al, 1998), Arbed opted to waive any licensing fees and claims to the use of the RBS connection in the public domain (Iwankiw \& Carter, 1996).

Following the waiver of licensing fees and claims by Arbed, AISC began a small study program to investigate the RBS connection as an alternative for steel moment frame seismic connections (Iwankiw \& Carter, 1996).

The RBS connection consists of a reduction in the cross-section of the beam flange over a specific region. The reduction of the cross-section of the flange reduces the bending capacity of the beam within that specific region. This allows for plastic hinging to be obtained at specific regions of the beam without compromising the shear capacity of the beam or the bending capacity of the beam at mid-span.

Typically the reduction in the beam flange is done to both the top and bottom flange. Tests results have shown that introduction of a reduced section to the bottom flange alone of the beam did not prevent brittle fracture in the welds of the flange to the column (Uang, et al, 2000).

There are three common types of RBS cuts: constant cut, tapered cut, or radius cut. It has been shown that optimizing the shape of the cut in the RBS flange can reduce the likelihood of a flange fracture (Jones et al, 2002). The most optimal shape is the radius cut (Jones et al, 2002). One means of fabricating the cut is by the use of a flame cutter. RBS connections can experience fracture at the cut caused by cracks forming 
from the rough flame cut (Roeder, 2002). Fracture can be prevented by grinding the rough flame cuts smooth.

The RBS connection has been prequalified for use in steel moment resisting frames (Iwankiw, 2004). This meets the requirement of AISC 341-05 Section 9.2a allowing engineers to use prescribed methods to detail the RBS connection in a steel moment resisting frame.

Reduced Beam Sections have the added advantage of generally being more efficient in fabrication and erection than the available reinforced connection alternatives (Iwankiw \& Carter, 1996). Typical connection reinforcement can include beam flange cover plates, ribs, haunches, and side plates. Shop cutting of the RBS connection has been found to be a much more cost effective alternative to the field work and extra material needed for reinforcing a connection (Iwankiw \& Carter, 1996). 


\section{Chapter 3 - Prototype Building Design}

The configuration of the prototype building used for this study (model building) was based upon the visual observation of typical buildings in the southern San Francisco Bay region. The layout of the model building was selected based on assumptions in an attempt to reflect typical construction for this type of commercial building. The lateral force resisting system and its layout were selected based on visual observation of an actual construction project and the connections were selected to reflect typical design practice for the lateral system and members. The purpose of this study was not to design a new building but rather to analyze how an assumed typical structure of this type of construction would respond during a severe earthquake.

A specific site for the prototype building was needed to determine code-based seismic loads. The following assumptions were made regarding the site and building for the study:

- Located in Santa Clara, California (latitude $37.315882 \mathrm{~N}$ and longitude $121.99569 \mathrm{~W})$

- Soil profile was Site Class D according to the definitions of the 2007 CBC

- Due to the seismicity of the region, the structure is assumed to have seismic loading govern over all other lateral loading conditions

- Occupancy Category II (Table 1-1 of ASCE 7-05)

The model building is a two-story commercial building. The floor plan is 128

feet by 128 feet L-shape with each leg having a width of $48 \mathrm{ft}$ [Figure 3-1]. The $2^{\text {nd }}$ floor centerline of beam height is 14 feet and the roof centerline of beam height is 16 feet for a total building height of 30 feet. 


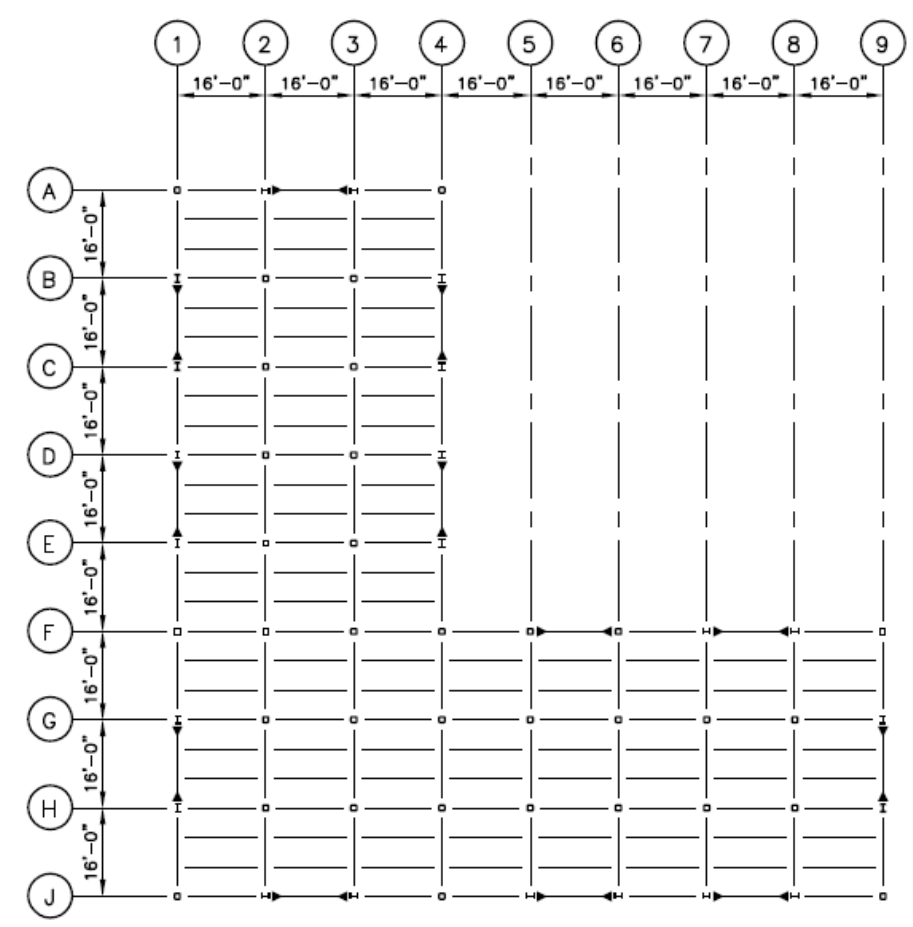

$\underline{\text { Second Floor Framing Plan }}$

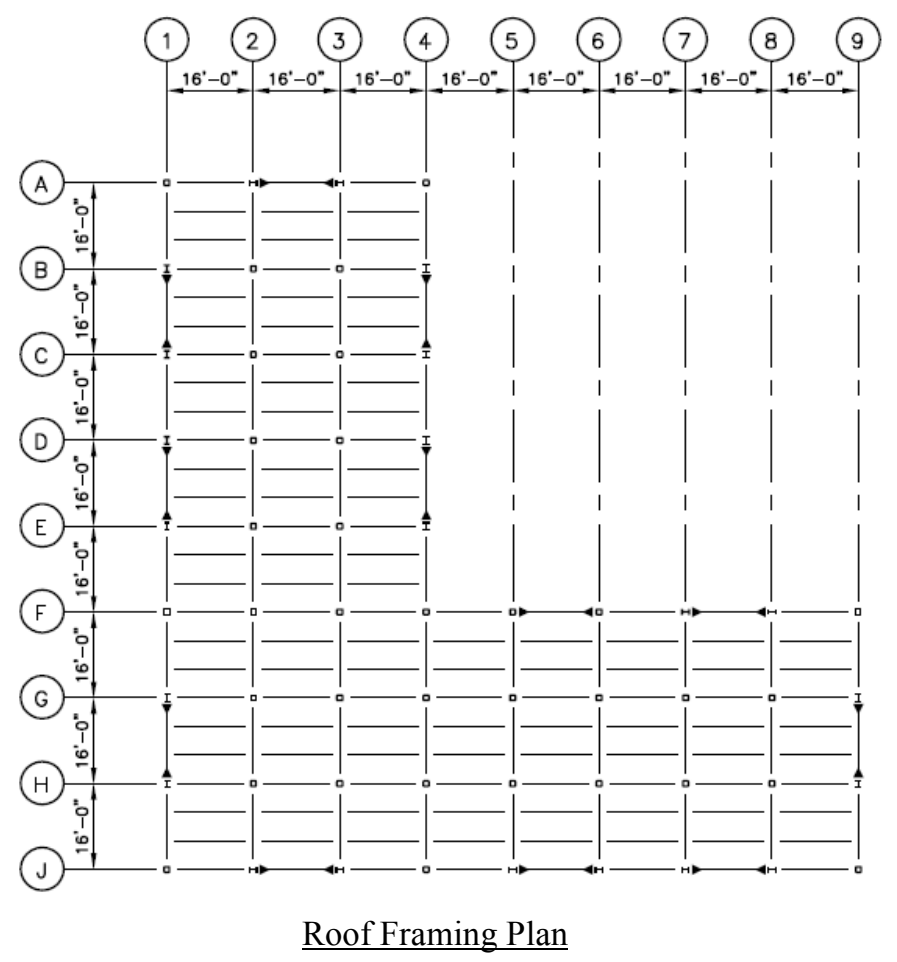

Figure 3-1 - Model Building Plans 
The assumed design loads were as follows:

- $\quad$ Roof Dead Load $=30$ psf

- $\quad$ Roof Live Load = 20 psf (2007 CBC Table 1607.1 for office building)

- $\quad$ Floor Dead Load $=40$ psf

- Floor Live Load = 50 psf (2007 CBC Table 1607.1 for office building)

The design dead loads were assumed to include the weight of all elements that contribute to the seismic weight at each story.

The building consists of wood framing to support dead and live loads and utilizes steel moment resisting frames to resist lateral loads. Each bay is $16^{\prime}$ in both the NorthSouth and East-West direction. Steel moment frames are located around the perimeter of the building as shown in Figure 3-2. Steel gravity columns are located at the corners of each bay unless replaced by moment frame columns. 


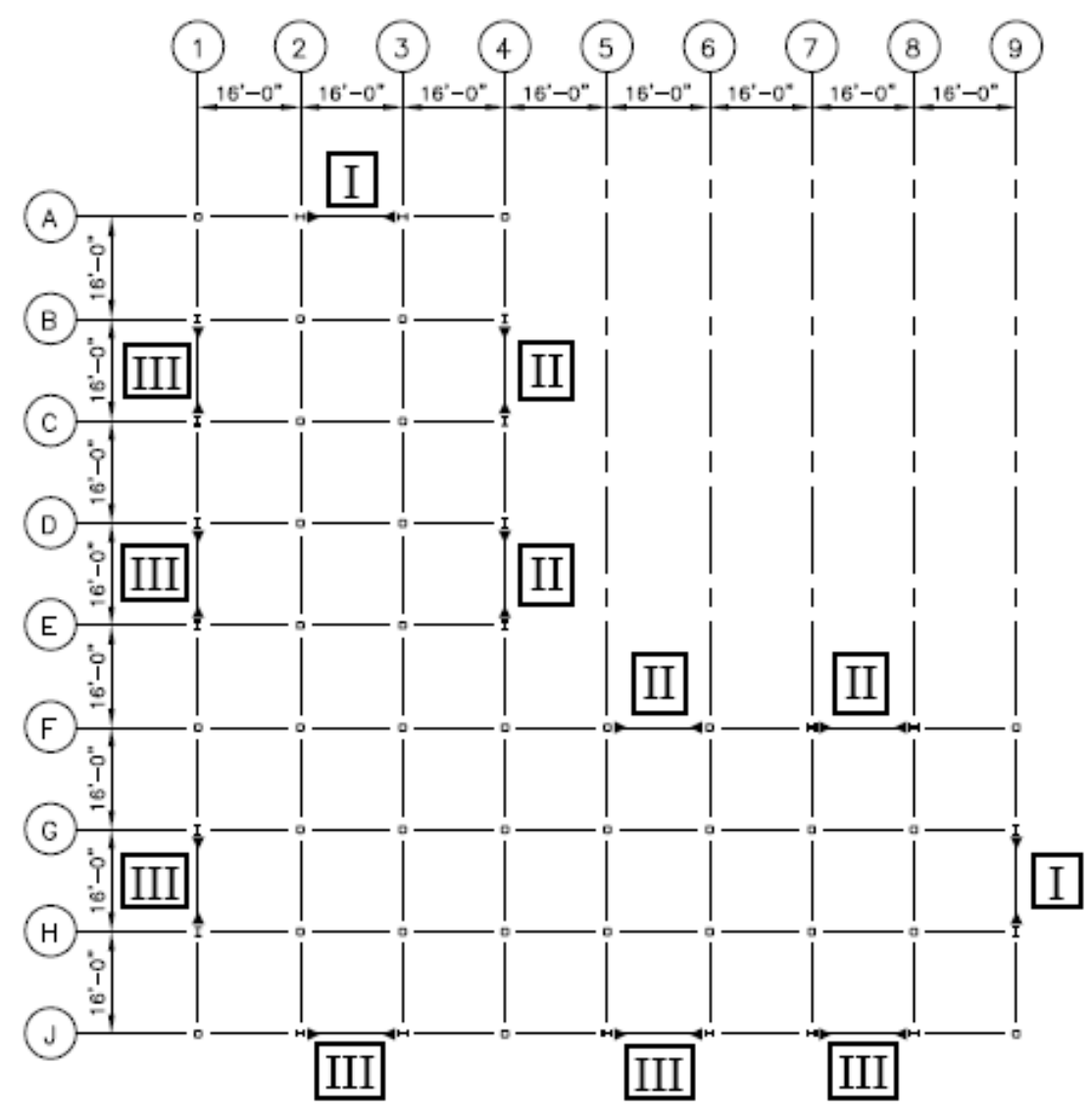

Figure 3-2 - Building Moment Frame Layout

It was assumed that the steel moment resisting frames would be detailed as Intermediate Steel Moment Frames (IMF) based on the requirements of ASCE 7-05 Section 12.2.5.7 which states that steel IMFs are permitted in SDC D up to a height of 35 feet. Table 12.2-1 in ASCE 7-05 lists the R factor for steel IMFs as 4.5 and the System Overstrength Factor, $\Omega$, as 3. According to ASCE 7-05 Table 12.2-1, Special Steel Moment Frames (SMF) have a higher R factor of 8.0 compared to the 4.5 for IMF. Although the SMF has a much higher R factor both the SMF and the IMF have the same $\Omega$ of 3.0. This implies that, although the factor increasing the required design force for 
the collectors would remain the same, the overall design force would be reduced by a factor of $\mathrm{R}_{\mathrm{SMF}} / \mathrm{R}_{\mathrm{IMF}}=1.78$.

Based on visual observation, all steel moment frames were assumed to have W16x67 columns and W21x57 beams at the first level and W16x45 beams at the roof level. Figure 3-3 shows the elevation of the typical steel moment frame.

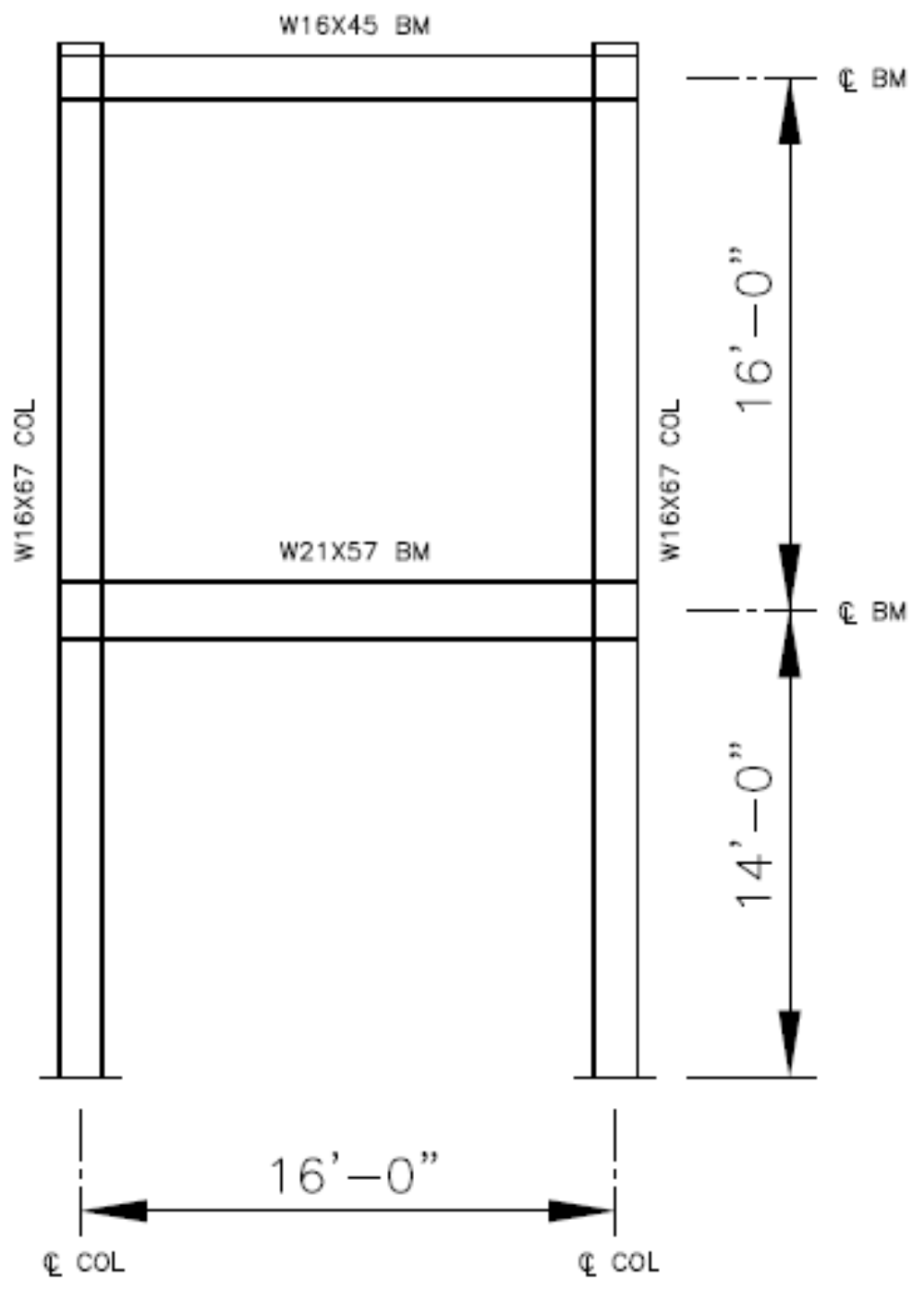

Figure 3-3 - Typical Moment Frame 
Reduced Beam Section (RBS) connections were assumed for the steel moment frame since they are representative of typical construction for the region and meet the requirements of ASCE 341-05 for IMF by being in accordance with AISC 358 [AISC 358-05 Table 2.1].

For a complete load path, lateral loads were assumed to be transferred from the diaphragm to the moment resisting frames using wood glulam collectors. Glulam collectors were assumed based on visual observation. The size of the glulam collectors was assumed to be adequate to have the capacity needed to meet the requirements of ASCE 7-05 to transfer lateral forces through axial loading and to support gravity loads from the floor or roof.

The diaphragms are assumed to be flexible and distribute seismic force to the moment resisting frames based upon an assumed tributary area. The tributary areas were divided into three separate zones, one along each collector line. Figures 3-4 and 3-5 show the seismic mass at each collector line tributary area for a North-South earthquake and an East-West earthquake respectively. Due to the symmetry of the building layout, the relationship between collector line and tributary area is independent of the direction of loading. Table 3-1 lists the tributary dead and live loads for each collector line tributary area shown on Figures 3-4 and 3-5. 


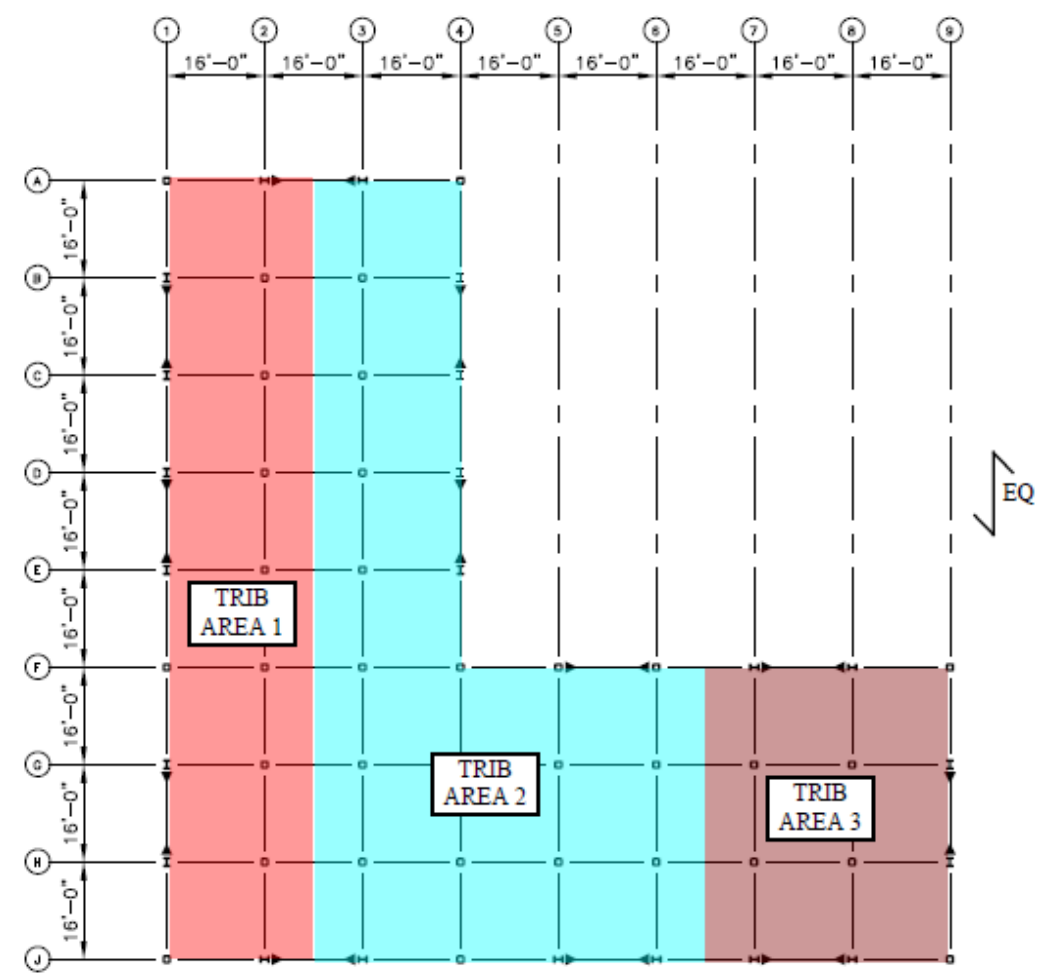

Figure 3-4 - Seismic Mass Tributary Area for N-S Earthquake

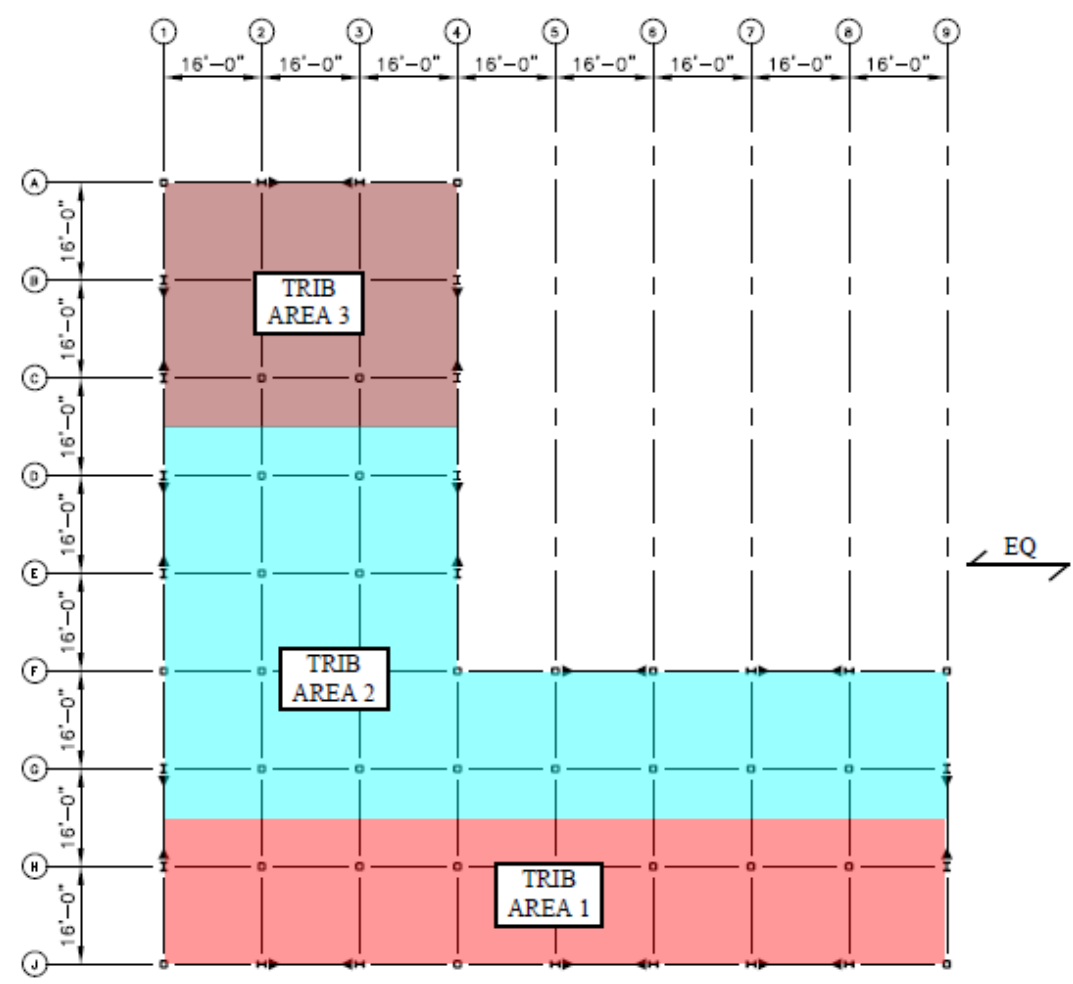

Figure 3-5 - Seismic Mass Tributary Area for E-W Earthquake 
The seismic mass along each collector line is divided evenly between each moment resisting frame along the collector line. Table 3-2 lists the seismic mass at the three different frame loading conditions.

Table 3-1 - Tributary Area Dead Load and Live Load

\begin{tabular}{|c|c|c|c|c|c|c|c|c|}
\hline & \multicolumn{2}{|c|}{ Tributary Area } & \multicolumn{3}{|c|}{ Tributary DL } & \multicolumn{3}{c|}{ Tributary LL } \\
\cline { 2 - 9 } Area & Roof & 2nd Floor & Roof & 2nd Floor & Total & Roof & 2nd Floor & Total \\
\hline 1 & $3072 \mathrm{ft}^{2}$ & $3072 \mathrm{ft}^{2}$ & $92.2 \mathrm{kips}$ & $122.9 \mathrm{kips}$ & $215.0 \mathrm{kips}$ & $61.4 \mathrm{kips}$ & $153.6 \mathrm{kips}$ & $215.0 \mathrm{kips}$ \\
\hline 2 & $4992 \mathrm{ft}^{2}$ & $4992 \mathrm{ft}^{2}$ & $149.8 \mathrm{kips}$ & $199.7 \mathrm{kips}$ & $349.4 \mathrm{kips}$ & $99.8 \mathrm{kips}$ & $249.6 \mathrm{kips}$ & $349.4 \mathrm{kips}$ \\
\hline 3 & $1920 \mathrm{ft}^{2}$ & $1920 \mathrm{ft}^{2}$ & $57.6 \mathrm{kips}$ & $76.8 \mathrm{kips}$ & $134.4 \mathrm{kips}$ & $38.4 \mathrm{kips}$ & $96.0 \mathrm{kips}$ & $134.4 \mathrm{kips}$ \\
\hline
\end{tabular}

Table 3-2 - Frame Seismic Mass

\begin{tabular}{|c|c|c|c|c|}
\hline \multirow[b]{2}{*}{ Frame } & \multirow{2}{*}{$\begin{array}{l}\text { Collector } \\
\text { Line }\end{array}$} & \multicolumn{3}{|c|}{ Seismic Mass } \\
\hline & & Roof & 2nd Floor & Total \\
\hline $\mathrm{I}$ & A \& 9 & 30.7 kips & 41.0 & 71.7 kips \\
\hline II & $F \& 4$ & 74.9 kips & 99.8 kips & 174.7 kips \\
\hline III & $J \& 1$ & $57.6 \mathrm{kips}$ & 76.8 kips & 134.4 kips \\
\hline
\end{tabular}

All gravity columns were assumed to be $\operatorname{HSS} 5 \times 5$ and continuous from the foundation to the roof. Gravity loads are assumed to be supported by a wood framing system that consists of purlins and subpurlins that transfer the gravity load to the glulam beams and steel columns. 


\section{Chapter 4 - Code Static Analysis}

The 2007 California Building Code (2007 CBC) was used to determine the code seismic load. The 2007 CBC is based upon ASCE 7-05. The code seismic loads were required to determine the collector design forces and to verify that the steel moment frames had adequate capacity to resist the design seismic forces. The LRFD design method was used for steel elements in this study.

The seismic loads were determined according to ASCE 7-05 Section 12.8 (see calculations in Appendix A). The Maximum Considered Earthquake (MCE) ground motion was determined using maps developed by the United States Geological Survey (USGS) (See Appendix A). The short period MCE ground motion ( $\left.\mathrm{S}_{\mathrm{DS}}\right)$, modified for the assumed Site Class of D, was 1.222g (see Appendix A). ASCE Table 11.6-1 lists Seismic Design Category $\mathrm{D}$ for $\mathrm{S}_{\mathrm{DS}} \geq 0.50$. The short period MCE ground motion was then modified to consider the Importance Factor, I = 1.0 for Occupancy Category II (ASCE 7-05 Table 11.5-1), and R factor (4.5) for the IMF. Thus, the ASCE 7-05 LRFD design seismic coefficient was 0.27 . The frame base shears corresponding to the three frames shown on Table 3-2 are listed on Table 4-1. The seismic loads were distributed vertically to the two levels of the building in accordance with Section 12.8.3 of ASCE 705 (see calculation in Appendix A).

Table 4-1 - Frame Design Base Shear

\begin{tabular}{|c|c|c|c|c|}
\hline \multirow[b]{2}{*}{ Frame } & \multicolumn{3}{|c|}{ Tributary Seismic Mass } & \multirow{2}{*}{$\begin{array}{c}\text { Tributary } \\
\text { Base Shear* }\end{array}$} \\
\hline & Roof & 2nd Floor & Total & \\
\hline I & 30.7 kips & 41.0 kips & 71.7 kips & 19.4 kips \\
\hline II & 74.9 kips & 99.8 kips & 174.7 kips & 47.2 kips \\
\hline III & 57.6 kips & $76.8 \mathrm{kips}$ & $134.4 \mathrm{kips}$ & 36.3 kips \\
\hline
\end{tabular}




\section{Collector Design}

For this study, only the collectors immediately adjoining the bay of the moment frames were evaluated. The collectors immediately adjacent to the moment frames are assumed to transfer the load associated with the seismic mass which is tributary to the moment frame and collected along the length of the collector. The seismic mass areas tributary to the collector in the North-South direction and the East-West direction is shown on Figure 4-1 and Figure 4-2 respectively.

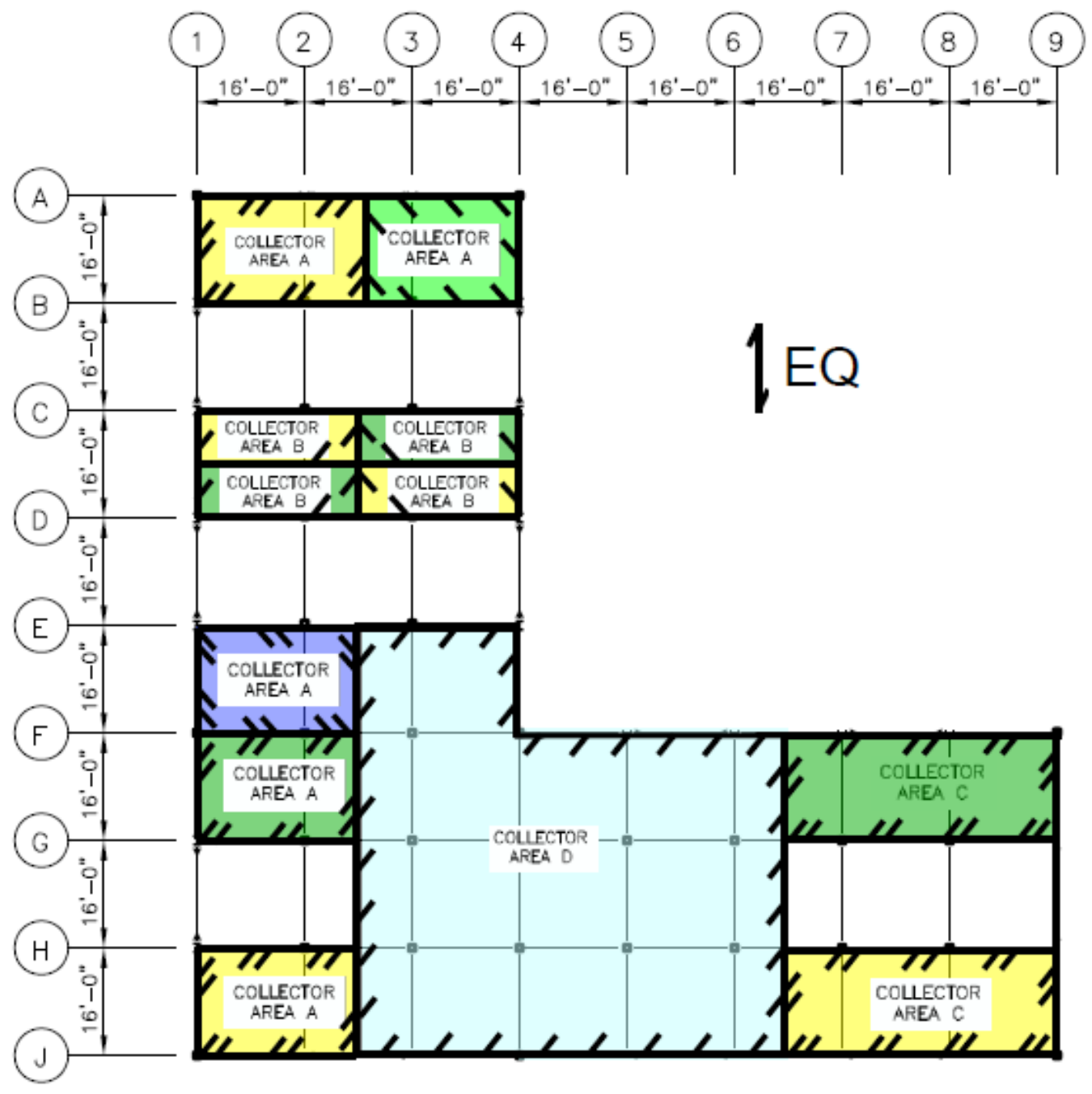

Figure 4-1 - Seismic Mass Tributary to Collectors for N-S Earthquake 


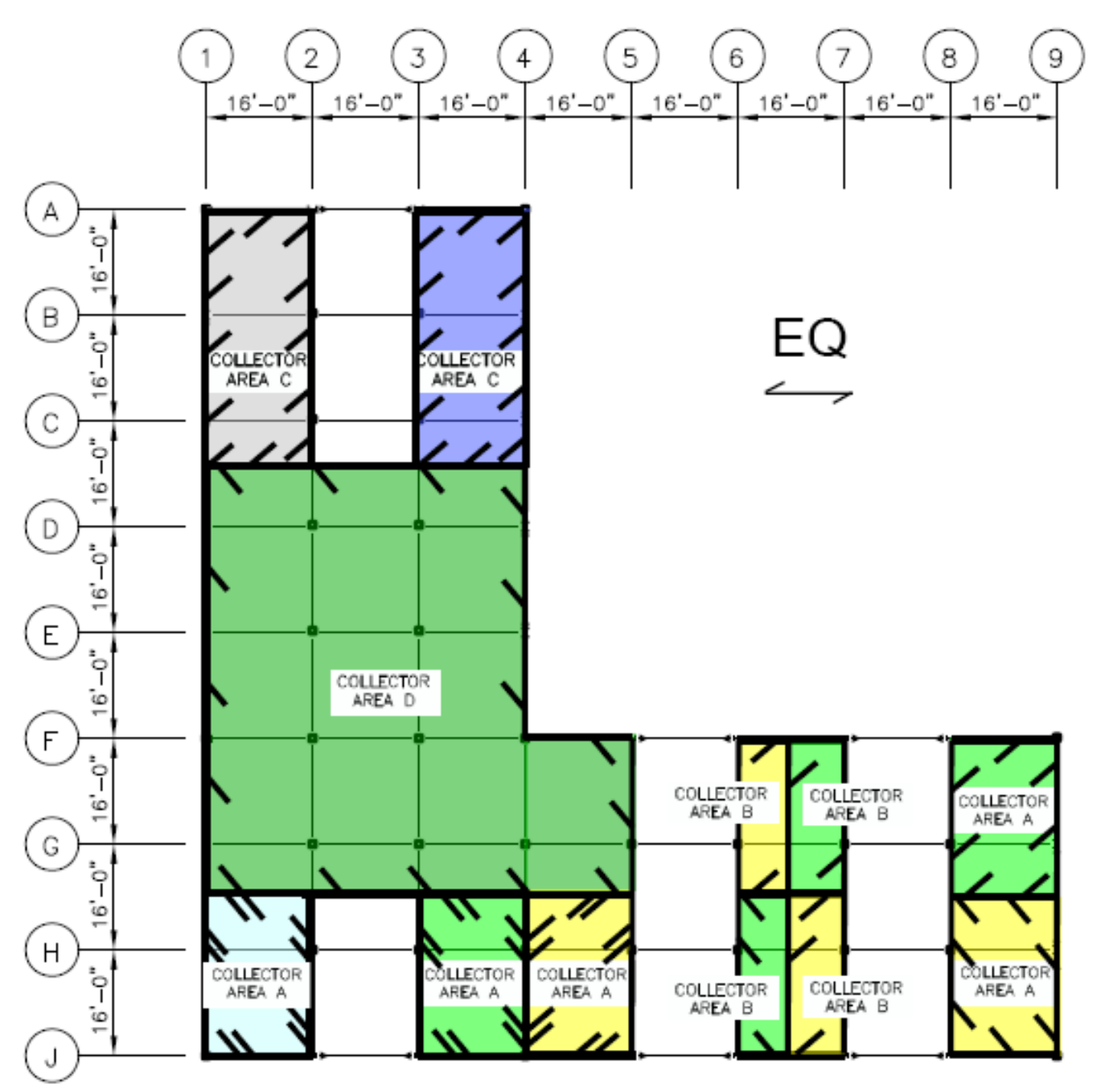

Figure 4-2 - Seismic Mass Tributary to Collectors for E-W Earthquake

Section 12.10.2.1 of ASCE 7-05 requires collectors, their splices, and their connections to be designed to resist the design seismic load amplified by the overstrength factor $\Omega_{0}$ as listed on Table 12.2-1 of ASCE 7-05. The value of $\Omega_{0}$ for an IMF is 3.0. Note $g$ on Table 12.2-1 in ASCE 7-05 states that the value for $\Omega_{\mathrm{o}}$ listed on Table 12.2-1 may be "reduced by subtracting one-half $(0.5)$ for structures with flexible diaphragms, but shall not be taken as less than 2.0 for any structure." The resulting design 
overstrength factor for this study was 2.5. The overstrength collector loads associated with the seismic masses shown in Figure 4-1 and Figure 4-2 are listed on Table 4-2.

Table 4-2 - Overstrength Collector Design Load

\begin{tabular}{|c|c|c|c|c|c|c|}
\hline \multicolumn{3}{|c|}{ Tributary Area } & \multicolumn{2}{c|}{ Tributary Floor Weight } & \multicolumn{2}{c|}{$\Omega_{\mathrm{o}} \mathrm{V}_{\text {collector }}$} \\
\hline & Roof & 2nd Floor & Roof & 2nd Floor & Roof & 2nd Floor \\
\hline A & $384 \mathrm{ft}^{2}$ & $384 \mathrm{ft}^{2}$ & $11.5 \mathrm{kips}$ & 15.4 kips & $7.8 \mathrm{kips}$ & $10.4 \mathrm{kips}$ \\
\hline B & $192 \mathrm{ft}^{2}$ & $192 \mathrm{ft}^{2}$ & 5.8 kips & 7.7 kips & 3.9 kips & $5.2 \mathrm{kips}$ \\
\hline C & $640 \mathrm{ft}^{2}$ & $640 \mathrm{ft}^{2}$ & $19.2 \mathrm{kips}$ & $25.6 \mathrm{kips}$ & $13.0 \mathrm{kips}$ & $17.3 \mathrm{kips}$ \\
\hline D & $3456 \mathrm{ft}^{2}$ & $3456 \mathrm{ft}^{2}$ & $103.7 \mathrm{kips}$ & $138.2 \mathrm{kips}$ & $70.0 \mathrm{kips}$ & $93.3 \mathrm{kips}$ \\
\hline
\end{tabular}

The glulam collectors were assumed to have sufficient bending capacity to support the dead load moment while also able to transmit the overstrength collector loads listed on Table 4-2 through axial compression or tension. It was also assumed that the collector connections and splices have adequate strength to transfer the loads listed on Table 4-2.

\section{$\underline{\text { Steel Connection Design }}$}

The beam-to-column subassembly is a key component for steel MRF. For this study, an RBS connection was chosen for the beam-to-column subassembly. The RBS connection was detailed to provide ductile rotation for the steel MRF. The RBS has a specially detailed cross-section that is intended to remain stable during inelastic deformation. The RBS will allow the connection to undergo ductile rotation without overloading critical components that may result in a brittle fracture.

The RBS connections for the steel moment frames were detailed according to the requirements of AISC 358-05 (see Appendix B). The size of the RBS connection was 
based on the code static seismic demand. For this study the RBS at the two different beams were detailed to have the smallest plastic section modulus allowed by the code, with the intent to reduce the amount of lateral load required to yield the steel moment frames. The RBS connections were also detailed to be located as close to the face of the column as practically possible.

The typical detail for the RBS is shown in Figure 4-3.

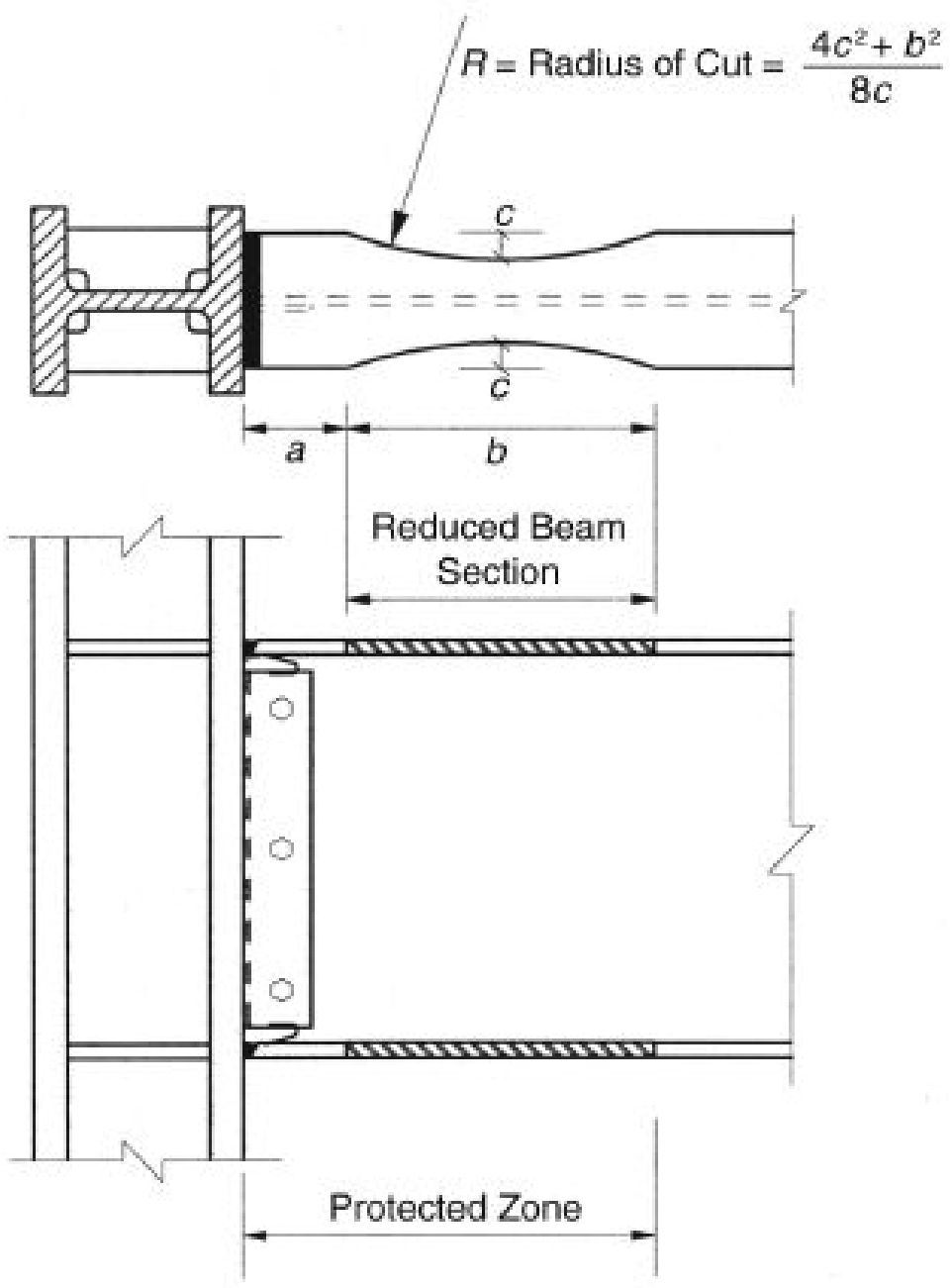

Figure 4-3 - AISC 358-05 Figure 5.1 Typical RBS Connection Detail (Reprinted with permission from AISC) 
The parameters of the RBS at the roof level beam (W16x45) are as follows:

$$
\begin{aligned}
& a=3.52^{\prime} \\
& b=4.576^{\prime} \\
& c=0.704 "
\end{aligned}
$$

The parameters of the RBS at the floor level beam (W21x57) are as follows:

$$
\begin{aligned}
& a=3.28^{\prime \prime} \\
& b=4.26 " \\
& c=0.656 "
\end{aligned}
$$

When the RBS were detailed, two moments were calculated for each of the two RBS. The first was the design plastic moment of the RBS $\left(M_{p, R B S}\right)$. This is the moment associated with the full plastic yielding at the center of the RBS that is used in design. Calculation of $\mathrm{M}_{\mathrm{p}, \mathrm{RBS}}$ is as follows:

$$
M_{p, R B S}=F_{y} Z_{e}
$$

(AISC 360-05 Eq. F2-1)

where

$$
\mathrm{Z}_{\mathrm{e}}=\text { the effective reduced plastic section modulus of the RBS }
$$

The RBS design plastic moments determined for the floor beam and roof beam were $5020.2 \mathrm{k}$-in and $3147.3 \mathrm{k}$-in respectively. $\mathrm{M}_{\mathrm{p}, \mathrm{RBS}}$ was used for this study to verify that the steel moment frames had adequate capacity to support the design loads according to the LRFD design requirements of ASCE 7-05. The second moment calculated was the Probable Plastic Moment of the RBS $\left(\mathrm{M}_{\mathrm{pr}, \mathrm{RBS}}\right)$. This is the estimated actual moment associated with the full plastic yielding of the center of the RBS. Calculation of $M_{p r, R B S}$ is as follows:

$$
M_{p r, R B S}=C_{p r} R_{y} F_{y} Z_{e}
$$


where $\mathrm{C}_{\mathrm{pr}}$ and $\mathrm{R}_{\mathrm{y}}$ are factors related to the expected yield strength of the steel. The factor $\mathrm{C}_{\mathrm{pr}}$ was determined to be 1.15 using ASCE 358-05 Eq. 2.4.3-2. The factor $\mathrm{R}_{\mathrm{y}}$ was determined to be 1.1 from Table I-6-1 of ASCE 341-05. The yield strength of the steel $\left(\mathrm{F}_{\mathrm{y}}\right)$ is $50 \mathrm{ksi}$. $\mathrm{M}_{\mathrm{pr}, \mathrm{RBS}}$ determined for the floor beam and roof beam were $7056.2 \mathrm{k}$-in and 4423.7 k-in respectively. 


\section{Chapter 5 - Frame Analyses}

The typical moment frame shown in Figure 3-3 was analyzed to 1) verify that it had adequate capacity to resist the design lateral forces and 2) determine the actual lateral force required to yield the frame. Three frame analyses were performed: Analysis 1) a force-controlled plastic mechanism analysis using linear member properties and the values of $\mathrm{M}_{\mathrm{p}, \mathrm{RBS}}$ determined in Chapter 4 to verify that the moment frame had adequate design capacity to resist the design lateral forces, Analysis 2) a force-controlled plastic mechanism analysis using linear member properties and the values of $\mathrm{M}_{\mathrm{pr}, \mathrm{RBS}}$ determined in Chapter 4 to gain better understanding of the lateral force required to cause first yield and form a collapse mechanism in the frame, and Analysis 3) a nonlinear pushover analysis performed using SAP 2000 and the nonlinear properties determined using ASCE 41-06 to determine the lateral force required to cause first yield and form a collapse mechanism in the frame. The results of Analysis 3 were used for the final comparison. A matrix summarizing the three analysis methods is shown in Table 5-1.

Table 5-1 - Analysis Matrix

\begin{tabular}{|c|c|c|}
\hline Analysis & Moment Strength & Method \\
\hline 1 & $\mathrm{M}_{\mathrm{p}-\mathrm{RBS}}$ & Flowchart (Figure 5-1) \\
\hline 2 & $\mathrm{M}_{\mathrm{pr}-\mathrm{RBS}}$ & Flowchart (Figure 5-1) \\
\hline 3 & $\mathrm{M}_{\mathrm{pr}-\mathrm{RBS}}$ & SAP \\
\hline
\end{tabular}

For this study the dead load acting on the beams was not considered during the frame analysis since the effect of the dead load bending moment $\left(\mathrm{M}_{\mathrm{DL}}\right)$ was expected to be relatively low compared to $\mathrm{M}_{\mathrm{p}, \mathrm{RBS}}$. Calculations in Appendix $\mathrm{C}$ show that for both the roof beam and the floor beam $\mathrm{M}_{\mathrm{DL}}$ was about $2 \%$ of $\mathrm{M}_{\mathrm{p}, \mathrm{RBS}}$. Since dead load acting 
vertically on the beams was not considered, it was assumed that under lateral loading plastic hinges would form at each end of a beam at the same time.

It was also assumed that the frames met the requirements for strongcolumn/weak-beam and thus plastic hinges would not form in the columns under lateral loading. Calculations in Appendix D verified this to be true.

\section{$\underline{\text { Analysis } 1}$}

To verify that the steel moment frame had adequate lateral capacity to resist the design tributary base shear, $\mathrm{V}$, an analysis was performed. The model was developed using RISA 2D and MS Excel to simulate a quick check that an engineer may perform when initially designing the frame and member sizes. RISA 2D was used to determine a relationships between base shear at the frame and moments developed at the RBS connections of each beam. Base shear / RBS moment relationships were determined for three states: 1) with both the roof beam and floor beam being fully elastic, 2) with the roof beam remaining elastic and the floor beam having plastic hinges (pinned connections) at the RBS, and 3) with the floor beam remaining elastic and the roof beam having plastic hinges (pinned connections) at the RBS. Using the base shear / RBS moment relationships determined from the RISA 2D model, a spreadsheet calculation was used to scale the lateral load to a higher value at which both the roof beam and floor beam would have bending moments equal to their bending capacity $\left(\mathrm{M}_{\mathrm{p}, \mathrm{RBS}}\right)$. The analysis process is outlined by the flowchart shown on Figure 5-1. 


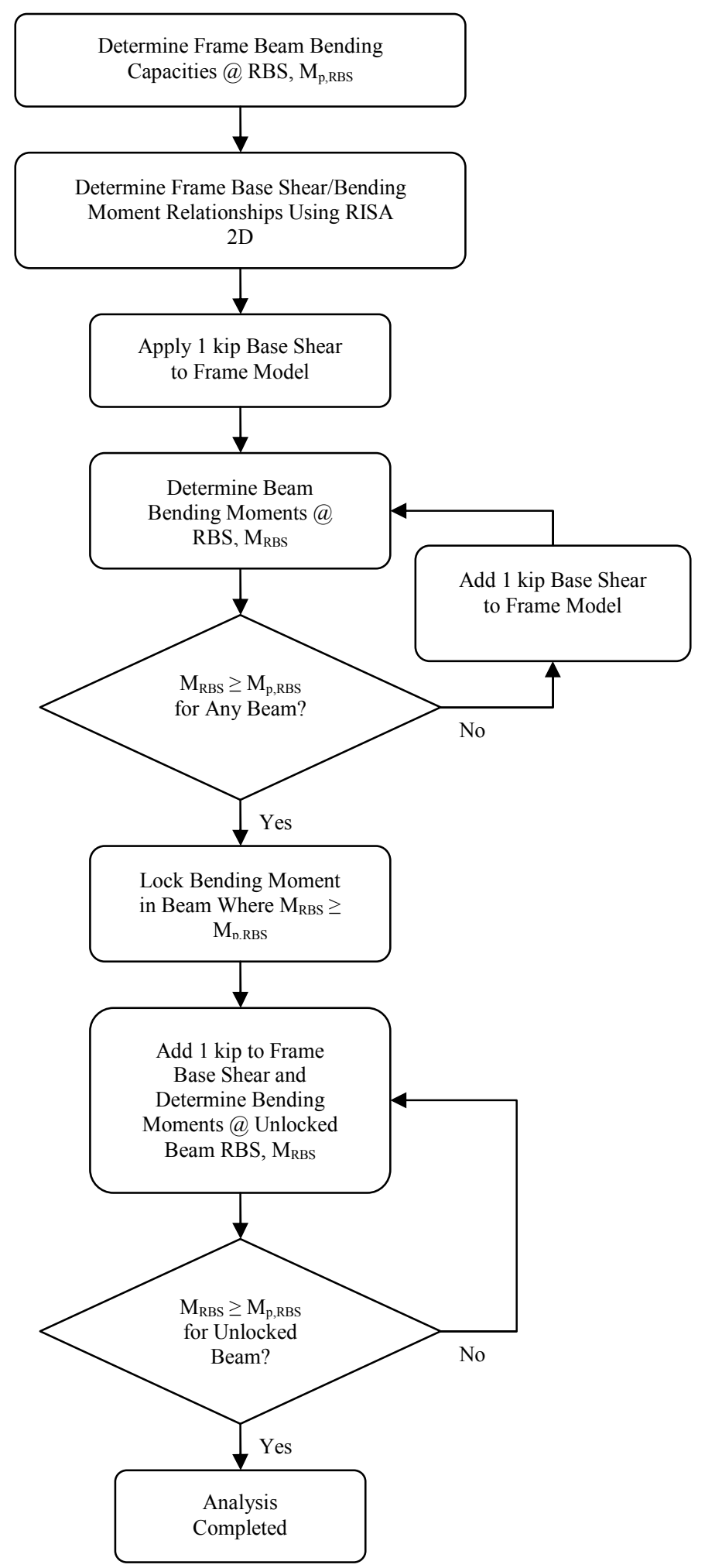

Figure 5-1 - Force-Controlled Plastic Mechanism Elastic Analysis Process 
A model was created in RISA 2D to determine a base shear / RBS moment relationship. The frame member sections and material properties were used for each element in the model. A one kip base shear was then distributed to the floor and roof level based on the vertical distribution of forces determined in Chapter 4. Figure 5-2 shows the forces applied at both the floor and roof level in the RISA 2D model.

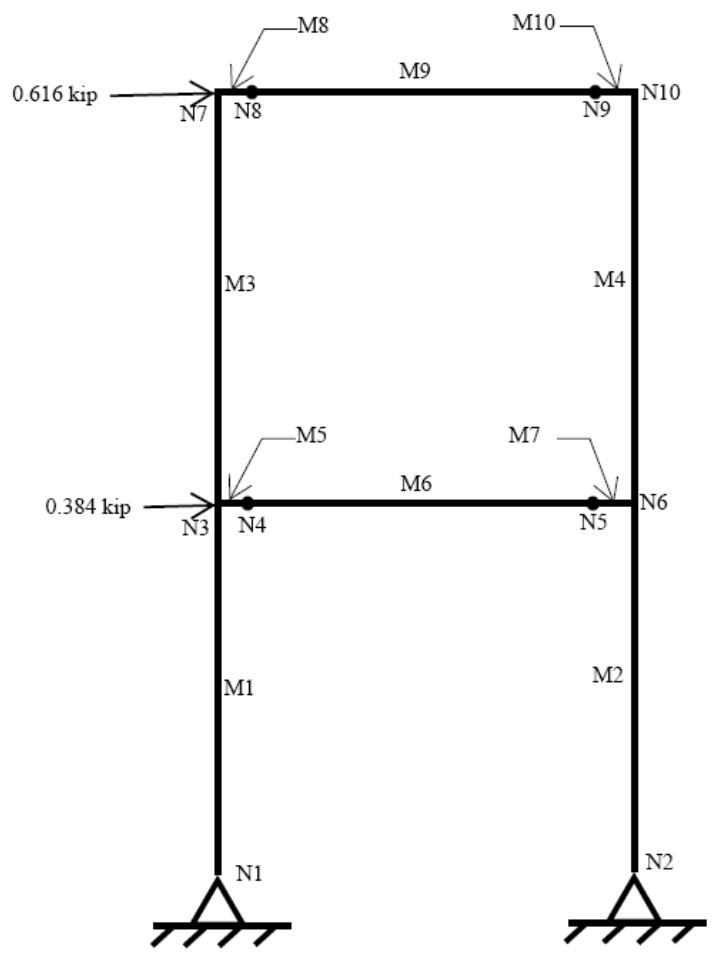

Figure 5-2 - RISA Model Frame

The analysis determined a resulting bending moment of 87.6 kip-in at the floor beam RBS and 28.8 kip-in at the roof beam RBS at the application of a 1 kip load as shown on Table 5-2. The output from the RISA 2D analysis is shown in Appendix E.

Table 5-2 - Analysis 1 Bending Moments

\begin{tabular}{|l|c|c|}
\hline & \multicolumn{2}{c|}{ Bending Moment @ RBS } \\
\hline Beam Condition & Floor Beam & Roof Beam \\
\hline Both Beams Fixed & 87.6 kip-in & 28.8 kip-in \\
\hline Floor Beam Pinned & - & 116.4 kip-in \\
\hline Roof Beam Pinned & 116.4 kip-in & - \\
\hline
\end{tabular}


Two more RISA 2D models were analyzed to determine the base shear / RBS moment relationships after the first set of plastic hinges had formed (in either the roof beam or the floor beam). These two models now had pins located at the RBS, one model with the RBS at the floor beam pinned, and one model with the RBS at the roof beam pinned. A one kip base shear was again distributed vertically to both the floor and roof beams of each model according to the static code analysis requirements. Figure 5-3 and Figure 5-4 show the forces applied and the pin locations for each model.

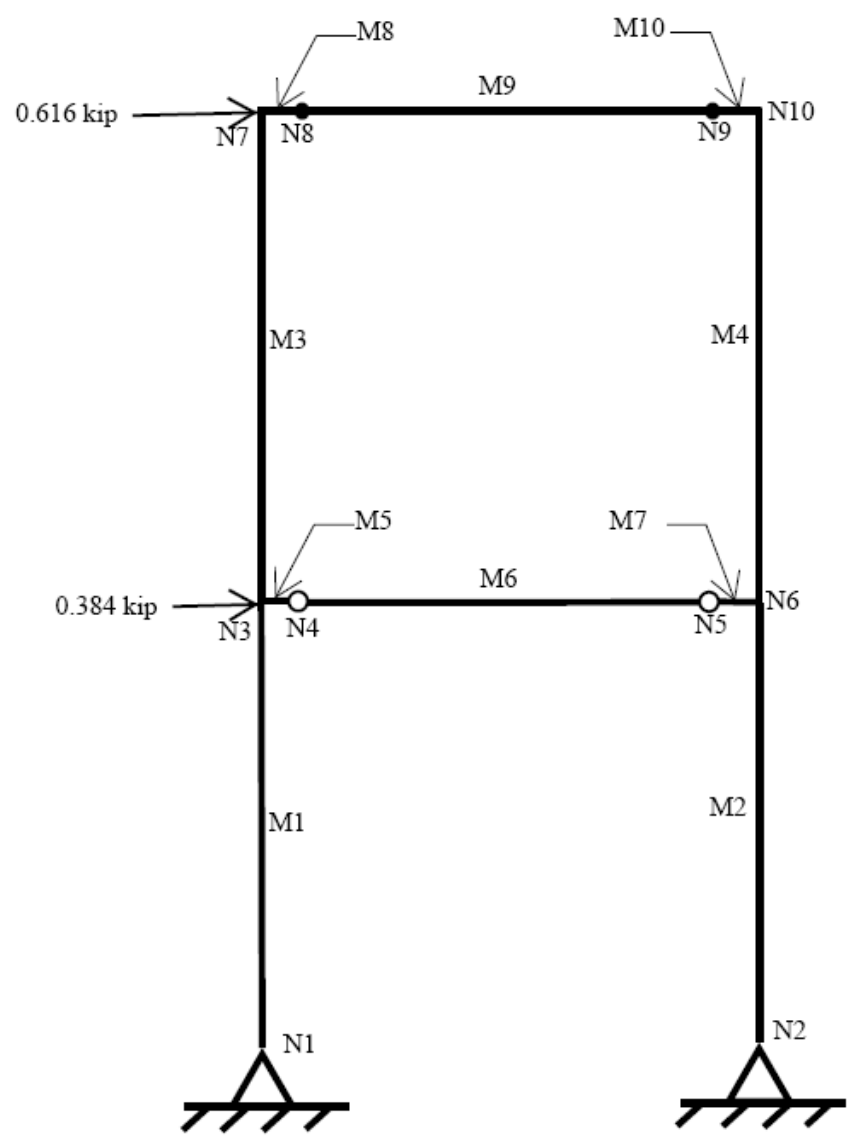

Figure 5-3 - RISA Frame Model with Floor Beam RBS Pinned 


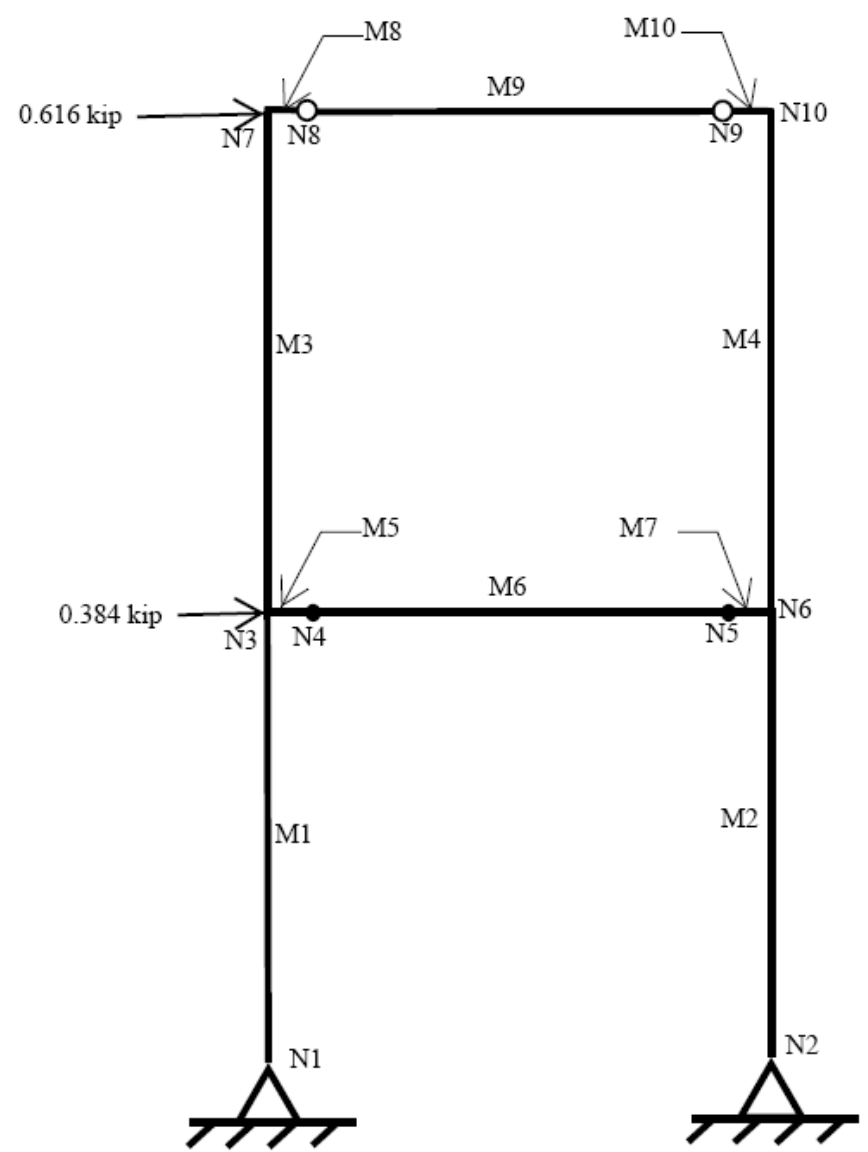

Figure 5-4 - RISA Frame Model with Roof Beam RBS Pinned

These two models were analyzed in a manner similar to the previous model and the base shear / RBS moment relationships were determined. With the floor beam pinned a one kip base shear would result in a bending moment of 116.4 kip-in at the roof beam RBS [see Table 5-2 and Appendix E]. Similarly, with the roof beam pinned a one kip base shear would result in a bending moment of 116.4 kip-in at the floor beam RBS [see Table 5-2 and Appendix E].

Once the base shear / RBS moment relationships were determined for the three frame configurations a spreadsheet was developed using MS Excel to apply monotonically increasing base shear to the frame until a collapse mechanism had formed 
in one of the beams. The spreadsheet analysis was started using a 1 kip base shear applied to the frame. Based on the relationships determined from the RISA models the moments in the RBS $\left(\mathrm{M}_{\mathrm{RBS}}\right)$ at both beams were calculated. $\mathrm{M}_{\mathrm{RBS}}$ was then compared to $M_{p, R B S}$ for each beam. If $M_{R B S}<M_{p, R B S}$ for each beam, then it was assumed that the frame was still completely elastic and an incremental increase in loading was applied.

Once $M_{R B S} \geq M_{p, R B S}$ for one of the beams occurred (in the case of this study the floor beam reached this point first) bending moment was held constant in the spreadsheet for that beam. The relative distribution of the load to each floor was then changed by using the relationships determined from the pinned-RBS RISA model to start the next loading stage. An additional 1 kip base shear was applied causing an increase in the bending moment at the RBS which had not yet formed a story mechanism (these RBS connections were assumed to still be elastic). $\mathrm{M}_{\mathrm{RBS}}$ in the roof beam was then compared to $\mathrm{M}_{\mathrm{p}, \mathrm{RBS}}$ as it had been in the previous loading stages. Once the loading stage was reached, where $M_{R B S} \geq M_{p, R B S}$ in the roof beam, it was assumed that a collapse mechanism had formed in the frame and the frame had completely yielded. The results at each loading stage are shown in Appendix F.

The resulting base shear to form a collapse mechanism in the frame $\left(\mathrm{V}_{\mathrm{p}, \text { frame }}\right)$ was 71 kips as seen in Appendix F. Figure 5-5 shows the results of Analysis 1, Analysis 2 and Analysis 3 plotted against the base shear required to form a collapse mechanism 


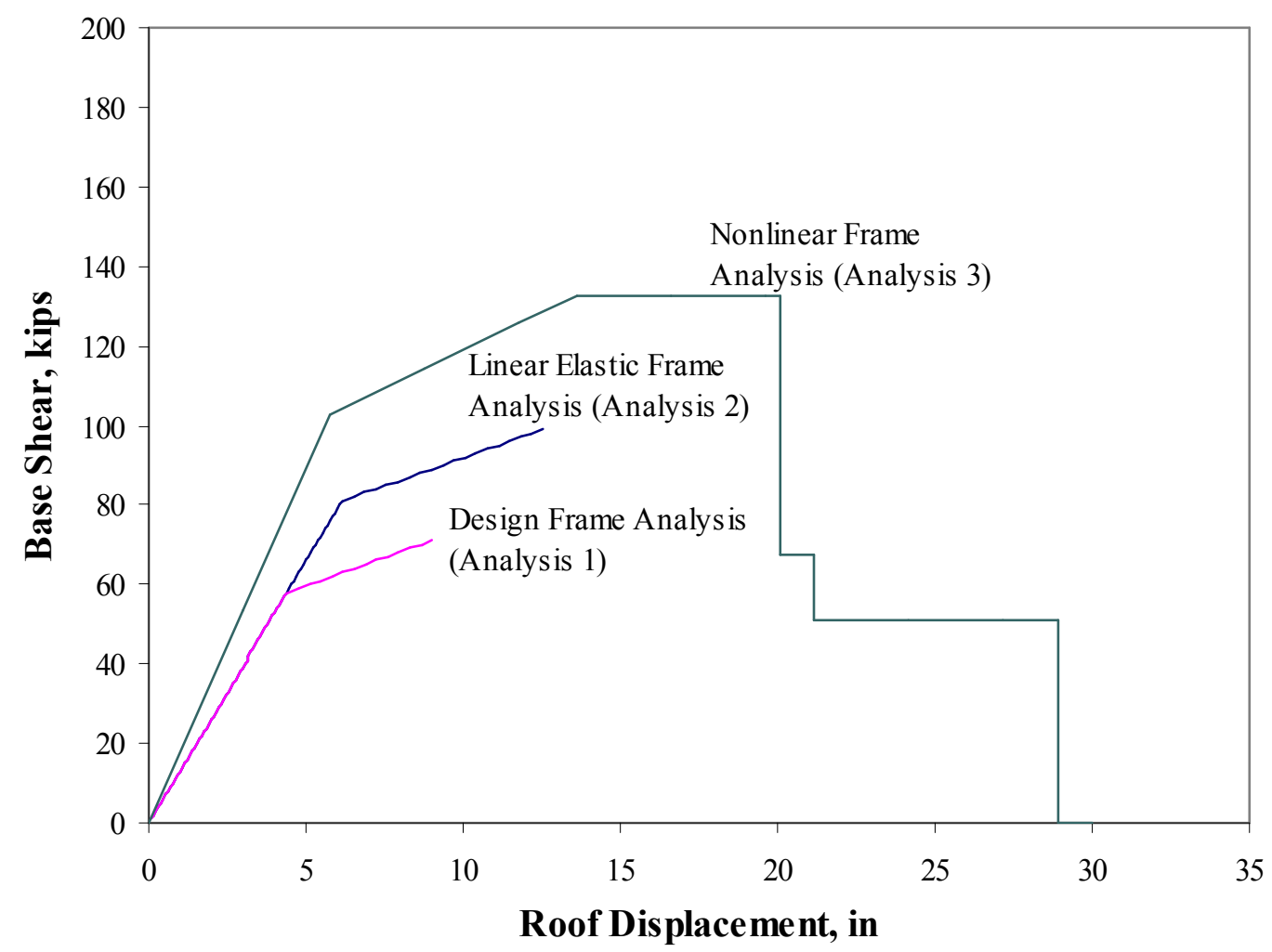

Figure 5-5 - Analysis Results (Base Shear vs. Roof Deflection)

Table 5-3 compares $V_{p, \text { frame }}$ to the design base shears for each of the three frames as determined in Chapter 3. Since the design base shear for each tributary frame area is less than $\mathrm{V}_{\mathrm{p} \text {,frame }}$ it is assumed that the steel moment frame meets the strength requirement of ASCE 7-05.

Table 5-3 - Design Base Shear to $\mathrm{V}_{\mathrm{p} \text {,frame }}$ Comparison

\begin{tabular}{|c|c|c|c|}
\hline Frame & $\mathrm{V}_{\text {design }}$ & $\mathrm{V}_{\text {p,frame }}$ & $\mathrm{V}_{\text {design }} / \mathrm{V}_{\text {p,frame }}$ \\
\hline I & 19.4 kips & $71.0 \mathrm{kips}$ & 0.27 \\
\hline II & $47.2 \mathrm{kips}$ & $71.0 \mathrm{kips}$ & 0.66 \\
\hline III & 36.3 kips & $71.0 \mathrm{kips}$ & 0.51 \\
\hline
\end{tabular}




\section{$\underline{\text { Analysis } 2}$}

For this analysis, $\mathrm{M}_{\mathrm{pr}, \mathrm{RBS}}$ was used to determine the lateral load required to yield the frame. This analysis differed from Analysis 1 in that the load needed to form the collapse mechanism was being determined instead of verifying that the design capacity was adequate for the design loads.

Analysis 2 was performed in the same manner as the previous frame analysis with the substitution of $\mathrm{M}_{\mathrm{pr}, \mathrm{RBS}}$ for $\mathrm{M}_{\mathrm{p}, \mathrm{RBS}}$. The results at each loading stage are shown in Appendix G. The required base shear to form a collapse mechanism in the frame $\left(\mathrm{V}_{\text {pr,frame }}\right)$ was 99 kips as seen in Figure 5-5 and in Appendix G.

The base shear determined in Analysis 2, which was determined using $\mathrm{M}_{\mathrm{pr}, \mathrm{RBS}}$, differed from the base shear determined in Analysis 1, which was determined using $M_{p, R B S}$, because it took into account the fact that the yield strength of the steel could actually be higher than $50 \mathrm{ksi}$ and was not reduced by $\phi$. The base shear determined in Analysis $2\left(\mathrm{~V}_{\text {pr,frame }}\right)$ represents the highest expected base shear needed to form a collapse mechanism in the frame.

Analysis 2 was performed as a quick means of verifying the output from Analysis 3. Since the results of Analysis 2 were relatively close to the results of Analysis 3 an added level of confidence was gained in the accuracy of the results of Analysis 3.

\section{$\underline{\text { Analysis } 3}$}

A nonlinear static pushover analysis was performed using SAP 2000. The nonlinear moment-rotation relationships for the RBS were developed using the ASCE 41- 
06 generalized force-deformation relationship described in Chapter 2. It was assumed that the post-yield stiffness was zero and hence there is no variation in force level between points $\mathrm{B}$ and $\mathrm{C}$ on the curve. In actual steel frames there is post-yield stiffness due to strain hardening but considering the limited scope of this study and the lack of consensus on specific values of post-yield stiffness this difference was not deemed critical. The nonlinear modeling parameters of Figure 2-2 were determined from ASCE 41-06 Table 5-6 for the roof beam RBS and the floor beam RBS. The nonlinear modeling parameters were determined using the connection type and beam sizes.

For the roof beam RBS the nonlinear modeling parameters were:

$$
\begin{aligned}
& \mathrm{a}=0.04517 \text { radians } \\
& \mathrm{b}=0.06517 \text { radians } \\
& \mathrm{c}=0.2
\end{aligned}
$$

For the floor beam RBS the nonlinear modeling parameters were:

$$
\begin{aligned}
& \mathrm{a}=0.04367 \text { radians } \\
& \mathrm{b}=0.06367 \text { radians } \\
& \mathrm{c}=0.2
\end{aligned}
$$

The yield moment for the beams was taken to be $\mathrm{M}_{\mathrm{pr}, \mathrm{RBS}}$ as calculated in Chapter 4. The yield rotation was assumed to be 0.0050 radians. The resulting generalized momentrotation curves for the roof beam RBS and floor beam RBS are shown on Figure 5-6. 


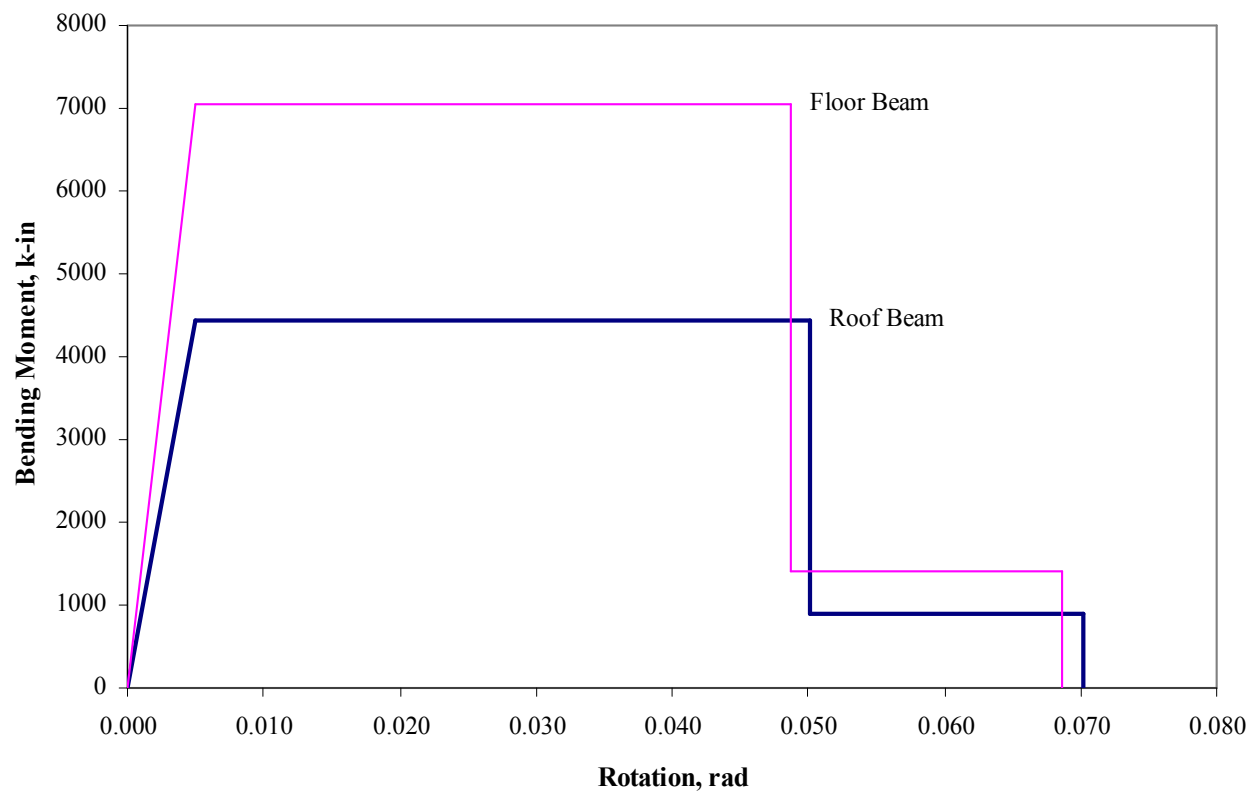

Figure 5-6 - ASCE 41-06 Generalized Moment-Rotation Curve for RBS Beam Hinge

An analytical model was then developed for SAP 2000 to perform the nonlinear static pushover analysis. The SAP 2000 model consisted of four column elements and six beam elements. The column and beam elements were modeled based on member centerlines. Nonlinear hinges were modeled at an offset of 5.81 inches from the column face at each end of the roof beam and at an offset of 5.41 inches from the column face at each end of the floor beam. These offsets represent the distance from the face of the column to the center of the RBS [Figure 5-7]. 


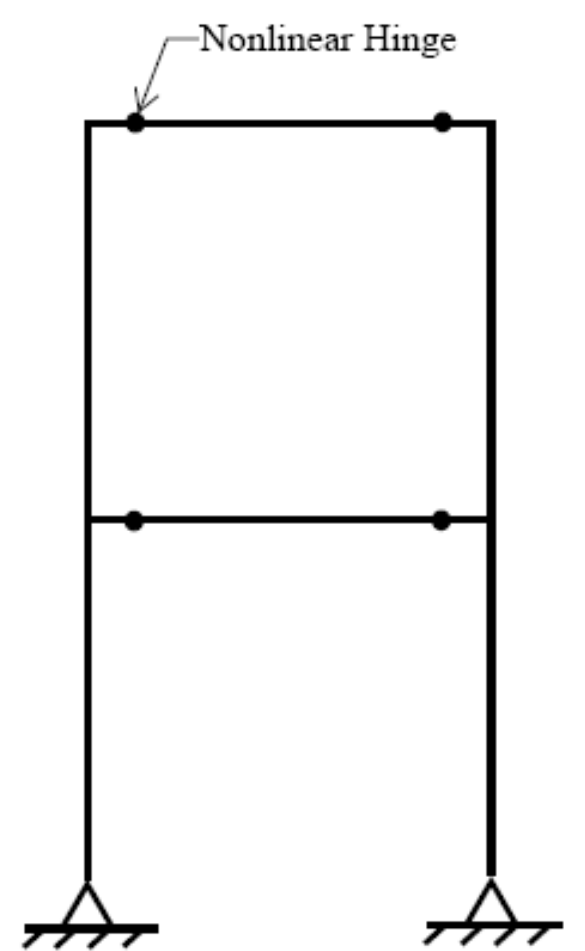

Figure 5-7 - SAP Nonlinear Pushover Model

The generalized moment-rotation curves of Figures 5-5 were used as the nonlinear hinge properties at the roof and floor RBS. The nonlinear static pushover function in SAP 2000 applies an increasing lateral load to the model until a preset displacement is reached. For this study the preset displacement was set to be 30 inches. The nonlinear static pushover curve for the frame is shown in Figure 5-5. The peak base shear the frame can resist ( $\left.\mathrm{V}_{\text {pr,frame }}\right)$ was 132.8 kips. 


\section{Chapter 6 - Results}

\section{Determination of Moment Frame Yielding}

The results from the second linear elastic analysis (Analysis 2) and the nonlinear analysis (Analysis 3) were compared to a base shear demand based on the IBC to determine if the steel moment frame would be expected to yield and eventually form a collapse mechanism during an actual earthquake. The base shear demand was determined as:

$$
V_{\text {demand }}=V_{\text {design }}\left(\frac{R}{I}\right)
$$

Multiplying by the $\mathrm{R}$ factor increases the design base shear to a value expected from linear response and thus without a reduction to account for the ductility of the lateral system. Similarly, the design base shear was divided by the importance factor to eliminate the code adjustment based on structural function. Thus, the base shear demand was assumed to reflect the actual MCE ground motion without any reduction for ductility in the lateral system and without any increase based on importance of the structure. This base shear demand is also the equivalent of a seismic coefficient equal to $\mathrm{S}_{\mathrm{DS}}$, the value from the USGS mapped MCE ground motion for the short period range. For each frame, the base shear demand $\left(\mathrm{V}_{\text {demand }}\right)$ was scaled from the design base shear listed in Table 41. The base shear demand for each frame is shown on Table 6-1. 
Table 6-1 - Base Shear Demand

\begin{tabular}{|c|c|c|}
\hline Frame & $\begin{array}{c}\text { Design Base Shear, } \\
\mathrm{V}_{\text {design }}\end{array}$ & $\begin{array}{c}\text { ASCE MCE } \\
\text { Base Shear Demand, } \\
\mathrm{V}_{\text {demand }}\end{array}$ \\
\hline I & $19.4 \mathrm{kips}$ & $87.1 \mathrm{kips}$ \\
\hline II & $47.2 \mathrm{kips}$ & $212.3 \mathrm{kips}$ \\
\hline III & $36.3 \mathrm{kips}$ & $163.3 \mathrm{kips}$ \\
\hline
\end{tabular}

The comparison of $\mathrm{V}_{\text {demand }}$ to $\mathrm{V}_{\mathrm{pr} \text {,frame }}$ determined in the linear elastic frame analysis and $\mathrm{V}_{\text {pr,frame }}$ determined in the nonlinear frame analysis is shown on Figure 6-1.

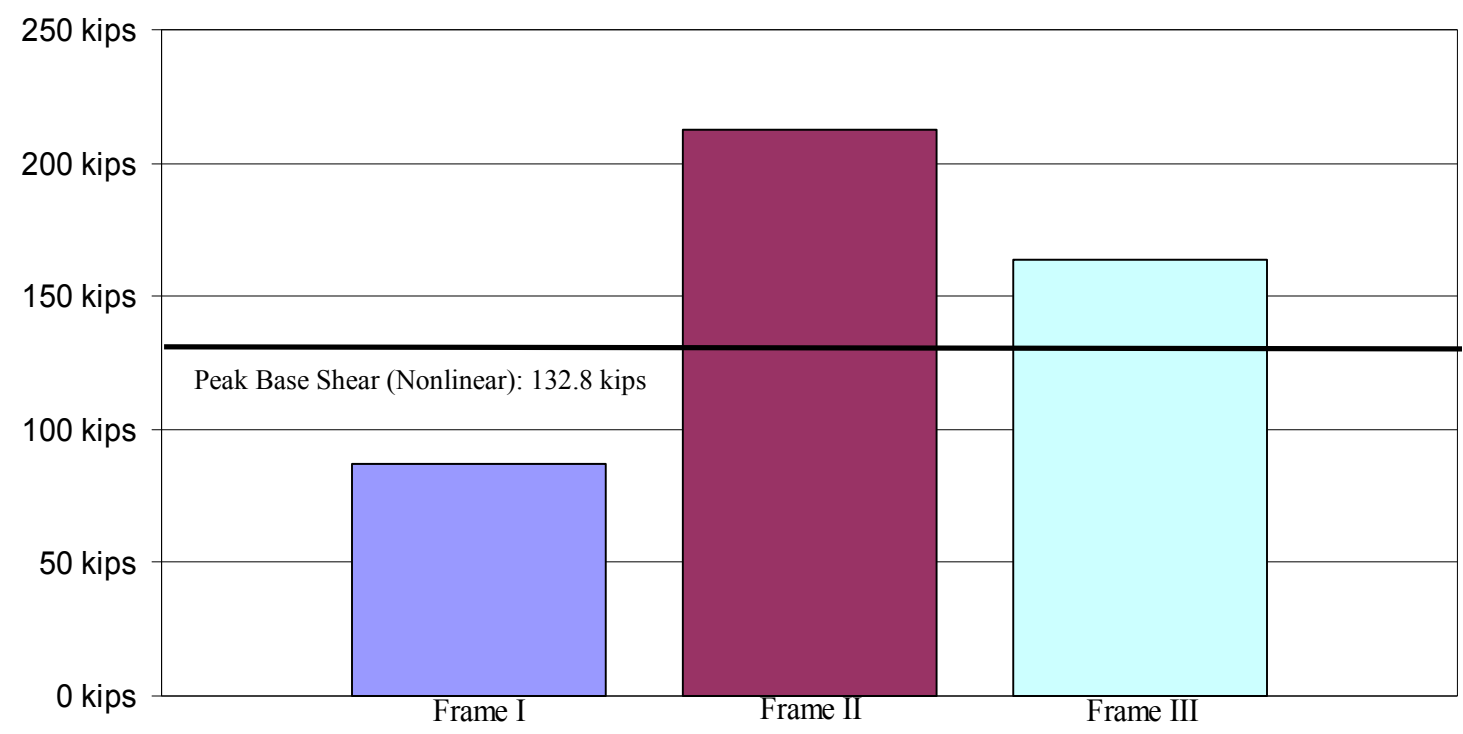

Figure 6-1 - Frame Base Shear Comparison

Considering Figure 6-1, Frames II and III were the only frames that had enough tributary seismic mass to form a collapse mechanism in the frame. Frame I did not have enough tributary mass to form a collapse mechanism. These results are based on the assumption that no redistribution of seismic forces from one frame to another occurs after a collapse mechanism forms in a frame. 


\section{Collector Design Capacity}

For the building system considered in this study, the collectors and their connections should have the capacity to transfer the load required to cause plastic hinging of the RBS connections at each end of the beams in the moment resisting frames. If the collectors or connections do not have sufficient capacity the system will likely not be able to dissipate energy through the inelastic deformation of the moment resisting frames as expected. Thus the system will be able to resist a maximum lateral load corresponding to the capacity of the weakest element, the collector.

To determine if the collectors have enough capacity to transfer the lateral load required to yield the steel moment frame, the results from the linear elastic analysis and the nonlinear analysis were compared to the design strength of the collectors. The design strengths of the collectors were determined in Chapter 4 and are shown on Table 4-2. For this study only the collector elements at frames with the largest tributary mass and the smallest tributary mass were examined.

The load that the collectors need to be able to transfer into the frame to cause a collapse mechanism to form ( $\left.\mathrm{P}_{\text {collectors,req }}\right)$ is equal to the required peak base shear $\left(\mathrm{V}_{\mathrm{pr}, \text { frame }}\right)$ less the load being transferred directly into the frame by the diaphragm. Figure 6-2 shows the different loads acting on the frame. 


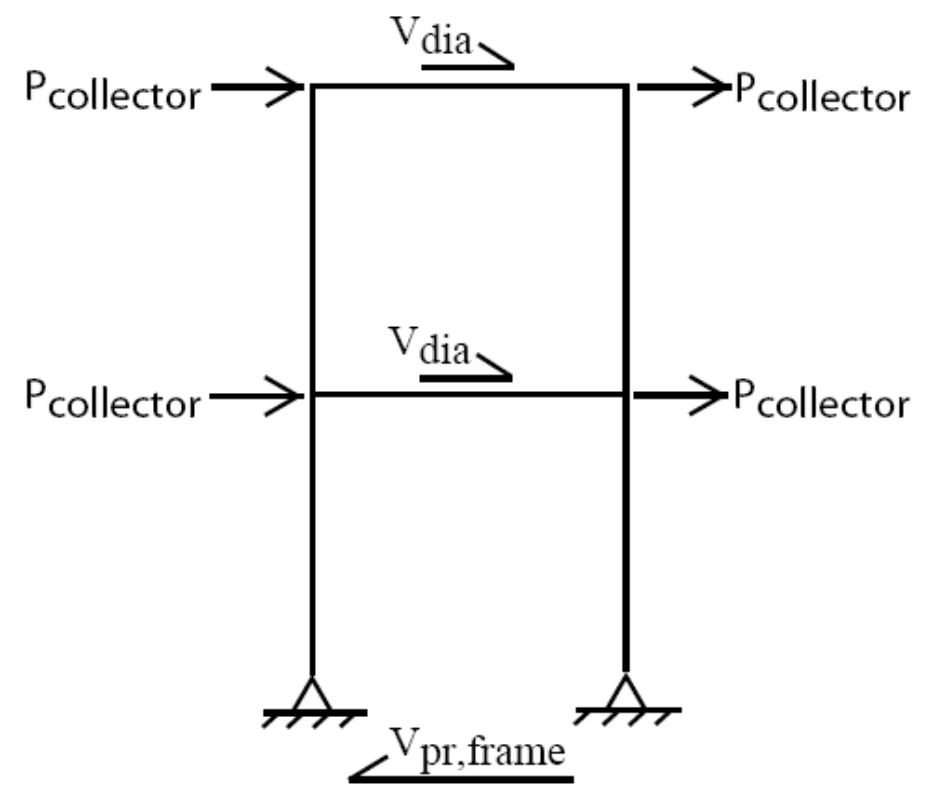

Figure 6-2 - Frame Loading Diagram

For this study the results of the nonlinear frame analysis were used to determine $\mathrm{V}_{\text {pr,frame, }}$ the required peak base shear, which was then distributed to the $2^{\text {nd }}$ floor and the roof levels using the vertical distribution factors from the $2007 \mathrm{CBC}$. The resulting shears were 75.8 kips at the $2^{\text {nd }}$ floor and 57 kips at the roof and are shown on Table $6-2$. The loads being transferred directly into the frame by the diaphragm were then subtracted from the frame story shear at both the $2^{\text {nd }}$ floor and roof levels. The resulting axial forces were $\mathrm{P}_{\text {collectors,req. }}$ This is the total force being collected at that location between both adjacent collectors. 
Table 6-2 - Collector Design Strength Comparison

\begin{tabular}{|c|c|c|c|c|c|}
\hline \multicolumn{6}{|c|}{ Tributary Area = 576 SF @ each level } \\
\hline & $\begin{array}{c}\text { Required } \\
\text { Peak Base } \\
\text { Shear, } V_{\mathrm{pr}}\end{array}$ & $\begin{array}{c}\text { Load From } \\
\text { Diaphragm, } \\
\mathrm{V}_{\text {diaphragm }}\end{array}$ & $\begin{array}{c}\text { Sum of Required } \\
\text { Collector Capacity, } \\
\mathrm{P}_{\text {collectors,req }}\end{array}$ & $\begin{array}{c}\text { Sum of Collector } \\
\text { Capacity, } \\
\mathrm{P}_{\text {collectors }} \\
\end{array}$ & $\mathrm{D} / \mathrm{C}$ \\
\hline 2nd Floor & $75.8 \mathrm{k}$ & $4.1 \mathrm{k}$ & $71.7 \mathrm{k}$ & $15.6 \mathrm{k}$ & 4.59 \\
\hline Roof & $57.0 \mathrm{k}$ & $3.1 \mathrm{k}$ & $53.9 \mathrm{k}$ & $11.7 \mathrm{k}$ & 4.61 \\
\hline \multicolumn{6}{|c|}{ Collectors B + D } \\
\hline & $\begin{array}{c}\text { Required } \\
\text { Peak Base } \\
\text { Shear, } V_{\mathrm{pr}}\end{array}$ & $\begin{array}{l}\text { Load From } \\
\text { Diaphragm, } \\
\mathrm{V}_{\text {diaphragm }}\end{array}$ & $\begin{array}{c}\text { Sum of Required } \\
\text { Collector Capacity, } \\
\mathrm{P}_{\text {collectors, req }}\end{array}$ & $\begin{array}{c}\text { Sum of Collector } \\
\text { Capacity, } \\
\text { Pollectors }\end{array}$ & $\mathrm{D} / \mathrm{C}$ \\
\hline 2nd Floor & $75.8 \mathrm{k}$ & $4.1 \mathrm{k}$ & $71.7 \mathrm{k}$ & $98.5 \mathrm{k}$ & 0.73 \\
\hline Roof & $57.0 \mathrm{k}$ & $3.1 \mathrm{k}$ & $53.9 \mathrm{k}$ & $73.9 \mathrm{k}$ & 0.73 \\
\hline
\end{tabular}

These axial demands were then compared to the collector design forces from Chapter 4 at each level. The collector design force at each level ( $\left.\mathrm{P}_{\text {collectors }}\right)$ is the sum of the adjacent collector design forces shown on Table 4-2. It should be noted that the required collector capacity is an "ultimate" level demand while the collector capacity is "strength" level capacity, therefore a $\mathrm{D} / \mathrm{C} \approx 2$ would be acceptable. Table $6-2$ shows that the collectors with the largest tributary mass (Collector D) would have adequate design capacity to transfer the load required by $\mathrm{P}_{\text {collectors,req, while the collectors at the frames }}$ with the smallest tributary mass (Collector B) would not. 


\section{Chapter 7 - Conclusions and Recommendations}

\section{$\underline{\text { Conclusions }}$}

After completing the work for this research the following conclusions to the initial research objectives were made:

- A literature review was conducted and a significant amount of published information was found on steel moment frame behavior, RBS connections, MCE ground motions, probabilistic seismic forces, and general seismic design principles. However, no published information could be found related to the use of steel MRF in wood-frame construction;

- A prototype two-story wood framed building with steel MRF for lateral support was defined and served as the basis for the seismic evaluation of critical structural elements;

- The seismic design load for the prototype building was determined based on the 2006 IBC and used to find an appropriate design force for the collector system;

- The RBS connections at both the $2^{\text {nd }}$ floor and roof levels were detailed according to the requirements of AISC 358-05 and were used in the frame analyses;

- Three pushover analyses were performed and the force associated with the formation of a collapse mechanism in the MRF was determined for each analysis; 
- Using the results of Analysis 1, the lateral load required to yield the frame $\left(\mathrm{V}_{\mathrm{p} \text {,frame }}\right)$ was compared to the design base shear of each frame and it was determined that the strength of the steel moment frames and RBS configuration was adequate to resist the design earthquake forces by $152 \%$ or more;

- The lateral load required to form a collapse mechanism, as determined in Analyses 2 and 3, was compared to the MCE base shear demand at each of the three frames and it was determined that Frame I would not have enough tributary mass to form a collapse mechanism while only Frame II and Frame III would have enough tributary mass to form a collapse mechanism;

- Collectors with larger tributary area requiring large design demands would have adequate strength to transfer the load required to form a collapse mechanism to the moment frame while collectors with smaller tributary area and thus smaller required design demands would not.

\section{$\underline{\text { Recommendations }}$}

Not all structures must be designed using the capacity design concept. Whether the load path of the system has the ability to resist the load required to cause the Preferred Failure Mode of the lateral force resisting system is irrelevant if all of the elements have enough capacity to support the loads developed during a future seismic event. But, should an earthquake occur that generates lateral loads greater than the strength of any 
member systems not designed using the capacity design concept have the potential for individual members to overload and fail before dissipation of energy can occur in the moment resisting frames. For this reason it is important to consider the possible reaction of the entire system during an extreme event and verify that, if the engineering intent is to have enough tributary mass to form collapse mechanisms in the moment frames, then the collectors would be strong enough to transfer that force.

For this prototype building it would be recommended to design the steel moment frames with a lateral force resisting strength that was balanced with the design lateral forces, thus while maintaining that formation of a frame collapse mechanism would occur at a lateral load not exceeding the strength of the collectors. This would ensure that the building would perform as expected and that the Preferred Failure Mode could be reached.

\section{$\underline{\text { Recommendation for Future Work }}$}

Two areas of further study of this topic are suggested by the author. First, research should be done to determine what would happen to a wood diaphragm if one or more of the steel moment resisting frames were to collapse. Would a flexible diaphragm designed to meet the requirements of the $2007 \mathrm{CBC}$ and $\mathrm{ASCE} 7-05$ have adequate strength to re-distribute lateral loads to unyielded steel moment frames if some of the steel moment frames in the building were to yield? Also, if the diaphragm were capable of re-distributing lateral loads what would happen to collectors and connections at frames with smaller tributary mass, which according to this study may not have yielded? 
Secondly, further study to determine the implications of using SMF and an R factor of 8.0 instead of IMF and an R factor of 4.5 in the design of the model building would be beneficial. Research questions to be considered in this area are:

- Would this cause the wood collectors to be "under-designed" for the steel moment frame selected for this study?

- What would the implications be during a severe earthquake? 


\section{$\underline{\text { References }}$}

1. 2007 CBC, “2007 California Building Code.” International Code Council, June 2007, Vol. 2

2. ANSI/AISC 341-05, "Seismic Provisions for Structural Steel Buildings." American Institute of Steel Construction, Nov. 2005

3. ANSI/AISC 358-05, "Prequalified Connections for Special and Intermediate Steel Moment Frames for Seismic Applications." American Institute of Steel Construction, Dec. 2005

4. ANSI/AISC 360-05, "Specifications for Structural Steel Buildings." American Institute of Steel Construction, Mar. 2005

5. ASCE 7-05, "Minimum Design Loads for Buildings and Other Structures." American Society of Civil Engineers, 2005

6. ASCE 41-06, "Seismic Rehabilitation of Existing Buildings." American Society of Civil Engineers, 2006

7. Iwankiw, N., Carter, C., (April 1996) "The Dogbone: A New Idea to Chew On." Modern Steel Construction, April 1996, 18-23

8. Iwankiw,N. (2004). "Seismic design enhancements and the reduced beam section detail for steel moment frames." Pract. Periodical on Struct. Des. and Constr., 9(2), 87-92

9. Jones,S.L., Fry,G.T., and Engelhardt,M.D. (April 2002). "Experimental evaluation of cyclically loaded reduced beam section moment connection." $J$. Struct. Engrg., 128(4), 441-451

10. Kochalski, G., Ericksen, J., (Jan 2007). "Prequalified Seismic Moment Connections." Modern Steel Construction, January 2007, 52-56

11. Leyendecker, E., Hunt, R., Frankel, A., Rusktales, K., (2000). "Development of Maximum Considered Earthquake Ground Motion Maps." Earthquake Spectra, $16(1), 21-40$

12. Lindeburg, M., McMullin, K., "Seismic Design of Building Structures." Professional Publications, Inc., Ninth Edition, 2008 
13. McMullin, K., "Civil Engineering 267 Reader." Associated Students Print Shop, San Jose State University, Fall 2008

14. Popov, E., Yang, T., Chang, S. (1998). "Design of steel MRF connections before and after 1994 Northridge earthquake." Engineering Structures, 20(12), 10301038

15. Riddell, M., Hidalgo, M., Cruz, E. (1989). "Response Modification Factors for Earthquake Resistant Design of Short Period Buildings." Earthquake Spectra, $5(3), 571-590$

16. Roeder,C.S. (2002). "Connection performance for seismic design of steel moment frames.” J. Struct. Engrg., 128(4), 517-525

17. Uang, C., "Balancing Structural Strength and Ductility Requirements." Modern Steel Construction, May 1994, 52-57

18. Uang, C., Yu, Q., Shane, N., and Gross, J., (2000). "Cyclic testing of steel moment connections rehabilitated with RBS or welded haunch." J. Struct. Engrg., $126(1), 57-68$

19. Zarghamee, M. (1995). "Northridge Postscript: Lessons on Steel Connections." Civil Engineering, 65(4), 68-71 


\section{APPENDIX A}

ASCE 7-05 Seismic Design Calculations 
$\underline{\text { Design Loads }}$

Flat Roof Load

\begin{tabular}{lll} 
& $\begin{array}{c}\text { Dead } \\
\text { Load }\end{array}$ & $\begin{array}{c}\text { Seismic } \\
\text { Load }\end{array}$ \\
\cline { 2 - 3 } & $30.0 \mathrm{psf}$ & $30.0 \mathrm{psf}$ \\
\hline Dead Load & $30.0 \mathrm{psf}$ & $30.0 \mathrm{psf}$ \\
Live Load & $20.0 \mathrm{psf}$ &
\end{tabular}

2nd Floor Load

Total

\begin{tabular}{lll} 
& $40.0 \mathrm{psf}$ & $40.0 \mathrm{psf}$ \\
\hline Dead Load & $40.0 \mathrm{psf}$ & $40.0 \mathrm{psf}$ \\
Live Load & $20.0 \mathrm{psf}$ &
\end{tabular}




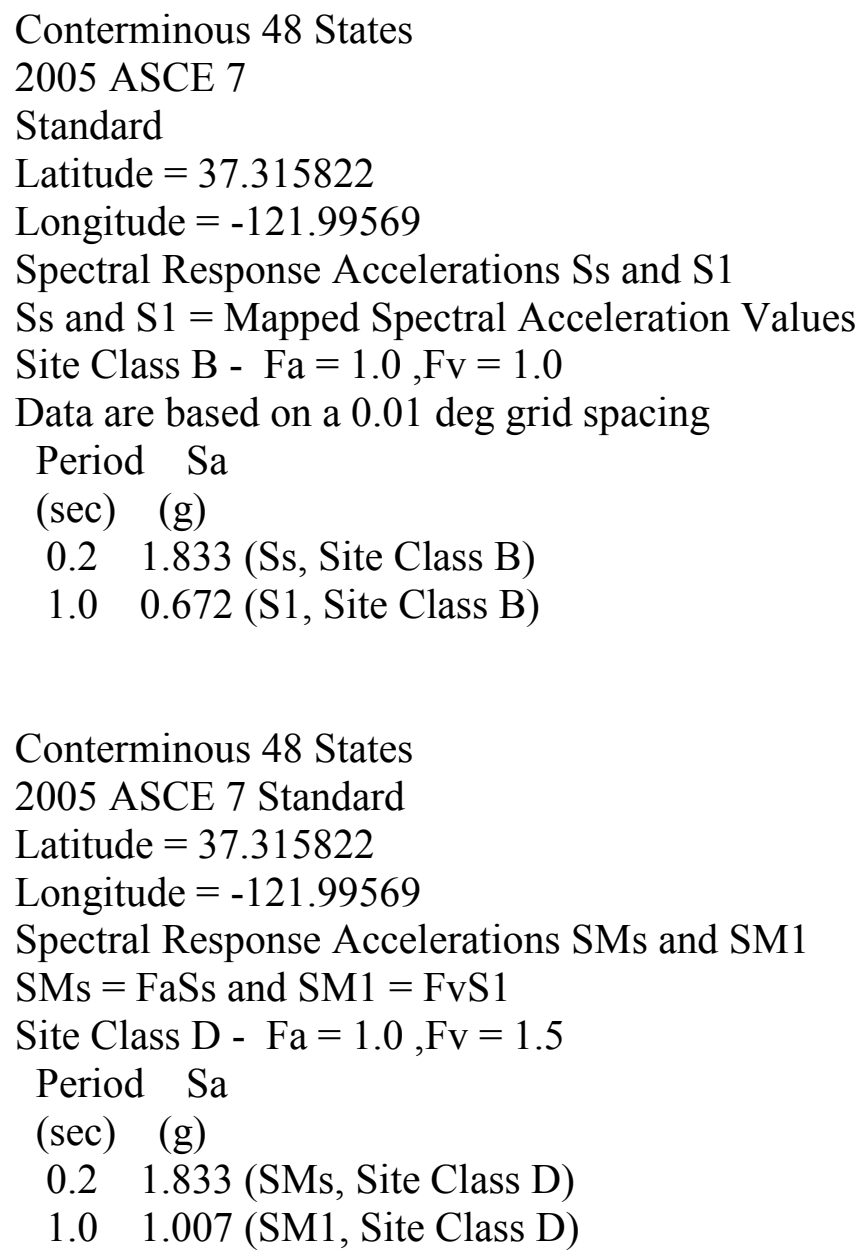

Conterminous 48 States 2005 ASCE 7 Standard

Latitude $=37.315822$

Longitude $=-121.99569$

$\mathrm{SDs}=2 / 3 \times \mathrm{SMs}$ and SD1 $=2 / 3 \times \mathrm{SM} 1$

Site Class D - $\mathrm{Fa}=1.0, \mathrm{Fv}=1.5$

Period $\mathrm{Sa}$

(sec) (g)

0.21 .222 (SDs, Site Class D)

$1.0 \quad 0.672$ (SD1, Site Class D) 
GOVERNING CODES \& DESIGN CRITERIA

California Building Code, 2007 Edition

${ }^{\star}$ ASCE/SEI 7-05 Minimum Design Loads for Buildings and Other Structures

\section{SEISMIC COEFFICIENTS}

\section{Structural Systems}

Structural System: Building Frame Systems: Intermediate steel moment frame

Occupancy Category

Site Class:

II

Seismic Design Category:

D (Table 11.6-1 and 11.6-2)

Upper Limit (for $\mathrm{T}<=\mathrm{TL}$ ):

Upper Limit (for $\mathrm{T}>\mathrm{TL}$ ):

Lower Limit:

Lower Limit $\left(S_{1}>=0.6\right)$ :

Time Period of the Structure:

Steel moment resisting frame (Table 12.8-2)

Height of structure in $\mathrm{f}$

Steel moment resisting frame (Table 12.8-2)

Seismic Base Shear:

Redundancy Factor:

For Diaphragm Design

Earthquake Load:

Strength Design:

Allowable Stress Design:

Overstrength Factor:

Deflection Amplification Factor:
$R=4.50\left({ }^{*}\right.$ Table $12.2-1$

$I=1.00\left({ }^{*}\right.$ Table $\left.11.5-1\right)$

$\mathrm{S}_{\mathrm{S}}=1.83$ (*Fig. $22-3$ )

$\mathrm{S}_{1}=0.67\left({ }^{*} \mathrm{Fig} .22-4\right)$

$F_{a}=1.00($ Table 1613.5.3(1))

$F_{v}=1.50($ Table $1613.5 .3(2))$

$\mathrm{S}_{\mathrm{MS}}=\mathrm{F}_{\mathrm{a}} \mathrm{S}_{\mathrm{S}}=1.83($ Eqn 16-37)

$S_{M 1}=F_{v} S_{1}=1.01($ Eqn $16-38)$

$S_{D S}=(2 / 3) S_{M S}=1.22($ Eqn $16-39)$

$S_{D 1}=(2 / 3) S_{M 1}=0.67($ Eqn $16-40)$

$\mathrm{C}_{\mathrm{S}}=\mathrm{S}_{\mathrm{DS}} /(\mathrm{R} / \mathrm{I})=\quad 0.27\left({ }^{*} \mathrm{Eqn} 12.8-2\right)$

$\mathrm{C}_{\mathrm{S}}=\mathrm{S}_{\mathrm{D} 1} /(\mathrm{T}(\mathrm{R} / \mathrm{I}))=0.35\left({ }^{*} \mathrm{Eqn} 12.8-3\right)$

$C_{S}=S_{01} T_{L} /\left(T^{2}(R / I)\right)=$ na ( ${ }^{*} E q n$ 12.8-4)

$\begin{aligned} C_{S} & =0.01\left({ }^{*} \text { Eqn 12.8-5) }\right.\end{aligned}$

$\mathrm{T}=\mathrm{C}_{\mathrm{t}} \mathrm{h}_{\mathrm{n}}{ }^{\mathrm{X}} \quad \mathrm{T}=0.425 \mathrm{sec} . \quad$ ( ${ }^{\star}$ Section 12.8.2.1

$c_{t}=0.028$

$\mathrm{h}_{\mathrm{n}}=\quad 30$

$\mathrm{x}=0.8$

$T_{L}=\quad 12\left({ }^{*}\right.$ Figure 22-16

$\mathrm{V}=\mathrm{C}_{5} \mathrm{~W}=\quad 0.27 \mathrm{~W}$

$\rho=1.00$

$\rho=1.00\left({ }^{\star}\right.$ Section 12.3.4.1)

$E_{n}=\rho V=0.272 \mathrm{~W}$

$E_{\mathrm{v}}=.2 \star \mathrm{S}_{\mathrm{DS}} \mathrm{D}=0.24 \mathrm{D}$

$E_{h} / 1.4=0.19397 \mathrm{~W}$

$E_{v} / 1.4=0.17457 \mathrm{D}$

( $\mathrm{Ev}=0$ for foundation design)

$\Omega_{0}=2.5$

$C_{d}=\quad 4.0$

Vertical Distribution

\begin{tabular}{|c|c|c|c|c|c|c|c|}
\hline \multirow{3}{*}{\multicolumn{2}{|c|}{$\begin{array}{r}\text { 1st Floor } \\
\text { Roof }\end{array}$}} & $w_{x}=$ & \multicolumn{2}{|r|}{$9984 \mathrm{ft}^{\wedge} 2$} & * 40 psf & $=399.4 \mathrm{k}$ & \\
\hline & & $w_{x}=$ & & $9984 \mathrm{ft}^{\wedge} 2$ & * $30 \mathrm{psf}$ & $=299.5 \mathrm{k}$ & \\
\hline & & & & & & $698.9 \mathrm{k}$ & \\
\hline & $k=1$ & & & $V=$ & $0.27 \mathrm{~W}$ & $=189.8 \mathrm{k}$ & \\
\hline Level & h & $h^{k}$ & $w_{x}$ & & $h^{k} w_{x}$ & $\mathrm{C}_{\mathrm{vx}}$ & $F_{x}$ \\
\hline Roof & 30 & 30 & 299.5 & & 8985.6 & 0.616 & $117.0 \mathrm{k}$ \\
\hline 2nd & 14 & 14 & 399.4 & & 5591.04 & 0.384 & $72.8 \mathrm{k}$ \\
\hline & & & & & 14576.6 & 1.000 & $189.8 \mathrm{k}$ \\
\hline
\end{tabular}




\section{APPENDIX B}

RBS Design 


\section{RBS Design - Roof (W16x45)}

AISC 358-05

A992

$\mathrm{F}_{\mathrm{y}}=50 \mathrm{ksi}$

$\mathrm{F}_{\mathrm{u}}=65 \mathrm{ksi}$

5.3.1 (5):

$$
\begin{aligned}
& \frac{16^{\prime} * 12}{16^{\prime \prime}}=12>7 \underline{\mathrm{ok}} \\
& Z_{\mathrm{e}}=\mathrm{Z}_{\mathrm{x}}-2 \mathrm{ct} \mathrm{t}_{\mathrm{bf}}\left(\mathrm{d}-\mathrm{t}_{\mathrm{bf}}\right) \\
& \mathrm{Z}_{\mathrm{x}}=82.3 \mathrm{in}^{3} \\
& b_{b f}=7.04 \Rightarrow c=0.1 b_{b f}=0.704 \text { (assume min } c \text { for lowest } M_{p, R B S} \text { ) } \\
& \mathrm{t}_{\mathrm{bf}}=0.565 \\
& \mathrm{~d}=16.1 " \\
& \mathrm{Z}_{\mathrm{e}}=82.3 \mathrm{in}^{3}-(2)(0.704 ”)(0.565 ”)\left(16.1 ”-0.565^{\prime \prime}\right)=69.94 \mathrm{in}^{3} \\
& \mathrm{M}_{\mathrm{p}, \mathrm{RBS}}=\Phi \mathrm{F}_{\mathrm{y}} \mathrm{Z}_{\mathrm{e}}=(0.9)(50 \mathrm{ksi})\left(69.94 \mathrm{in}^{3}\right)=3147.3 \mathrm{k}-\mathrm{in} \\
& \mathrm{M}_{\mathrm{pr}, \mathrm{RBS}}=\mathrm{C}_{\mathrm{pr}} \mathrm{R}_{\mathrm{y}} \mathrm{F}_{\mathrm{y}} \mathrm{Z}_{\mathrm{e}}=(1.15)(1.1)(50 \mathrm{ksi})\left(69.94 \mathrm{in}^{3}\right)=4423.7 \mathrm{k}-\mathrm{in} \\
& \mathrm{C}_{\mathrm{pr}}=\frac{\mathrm{F}_{\mathrm{y}}+\mathrm{F}_{\mathrm{u}}}{2 \mathrm{~F}_{\mathrm{y}}}=1.15>1.2 \underline{\mathrm{ok}} \\
& \mathrm{R}_{\mathrm{y}}=1.1 \text { (see AISC 341-05 Table I-6-1) }
\end{aligned}
$$


$\underline{\text { RBS Design - Roof (W16x45) }}$

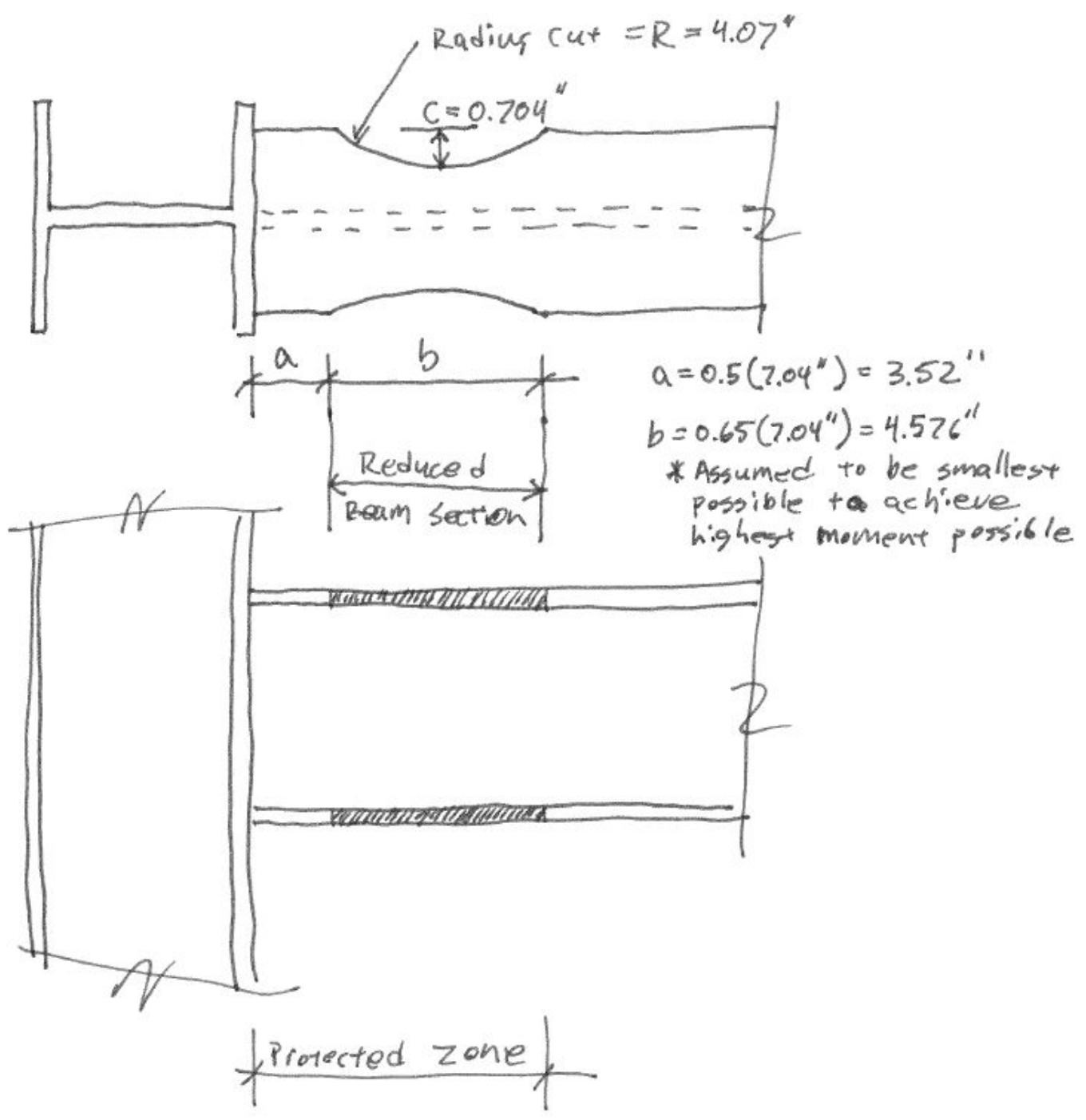

62 


\section{RBS Design - Floor (W21x57)}

AISC 358-05

A992

$\mathrm{F}_{\mathrm{y}}=50 \mathrm{ksi}$

$\mathrm{F}_{\mathrm{u}}=65 \mathrm{ksi}$

5.3.1 (5):

$$
\begin{aligned}
& \frac{16^{\prime} * 12}{21.1^{\prime \prime}}=9.1>7 \underline{\mathrm{ok}} \\
& Z_{e}=Z_{x}-2 c t_{b f}\left(d-t_{b f}\right) \\
& \mathrm{Z}_{\mathrm{x}}=129 \mathrm{in}^{3} \\
& b_{b f}=6.56 \Rightarrow c=0.1 b_{b f}=0.656 \text { (assume min } c \text { for lowest } M_{p, R B S} \text { ) } \\
& \mathrm{t}_{\mathrm{bf}}=0.65^{\prime \prime} \\
& \mathrm{d}=21.1 " \\
& \mathrm{Z}_{\mathrm{e}}=129 \mathrm{in}^{3}-(2)(0.656 ”)(0.65 ”)(21.1 ”-0.65 ”)=111.56 \mathrm{in}^{3} \\
& \mathrm{M}_{\mathrm{p}, \mathrm{RBS}}=\Phi \mathrm{F}_{\mathrm{y}} \mathrm{Z}_{\mathrm{e}}=(0.9)(50 \mathrm{ksi})\left(111.56 \mathrm{in}^{3}\right)=5020.2 \mathrm{k}-\mathrm{in} \\
& \mathrm{M}_{\mathrm{pr}, \mathrm{RBS}}=\mathrm{C}_{\mathrm{pr}} \mathrm{R}_{\mathrm{y}} \mathrm{F}_{\mathrm{y}} \mathrm{Z}_{\mathrm{e}}=(1.15)(1.1)(50 \mathrm{ksi})\left(111.56 \mathrm{in}^{3}\right)=7056.2 \mathrm{k}-\mathrm{in} \\
& \mathrm{C}_{\mathrm{pr}}=\frac{\mathrm{F}_{\mathrm{y}}+\mathrm{F}_{\mathrm{u}}}{2 \mathrm{~F}_{\mathrm{y}}}=1.15>1.2 \underline{\mathrm{ok}} \\
& \mathrm{R}_{\mathrm{y}}=1.1 \text { (see AISC 341-05 Table I-6-1) }
\end{aligned}
$$


$\underline{\text { RBS Design - Floor (W21x57) }}$

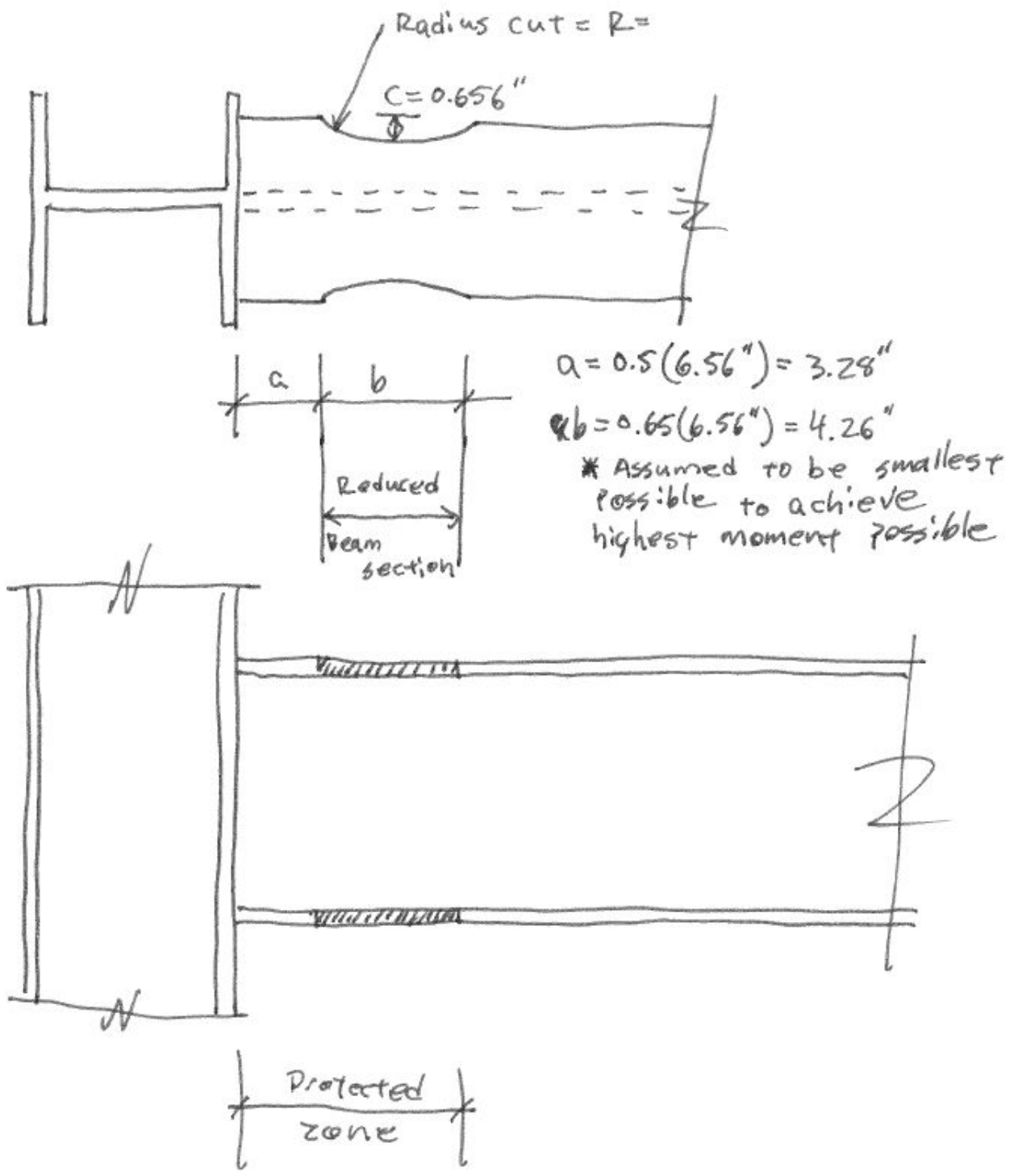




\section{APPENDIX C}

Comparison of $\mathrm{M}_{\mathrm{DL}}$ to $\mathrm{M}_{\mathrm{p}, \mathrm{RBS}}$ 
Comparison of $\mathrm{M}_{\mathrm{DL}} \underline{\text { to } \mathrm{M}_{\mathrm{p}, \mathrm{RBS}}-\operatorname{Roof}(\mathrm{W} 16 \times 45)}$

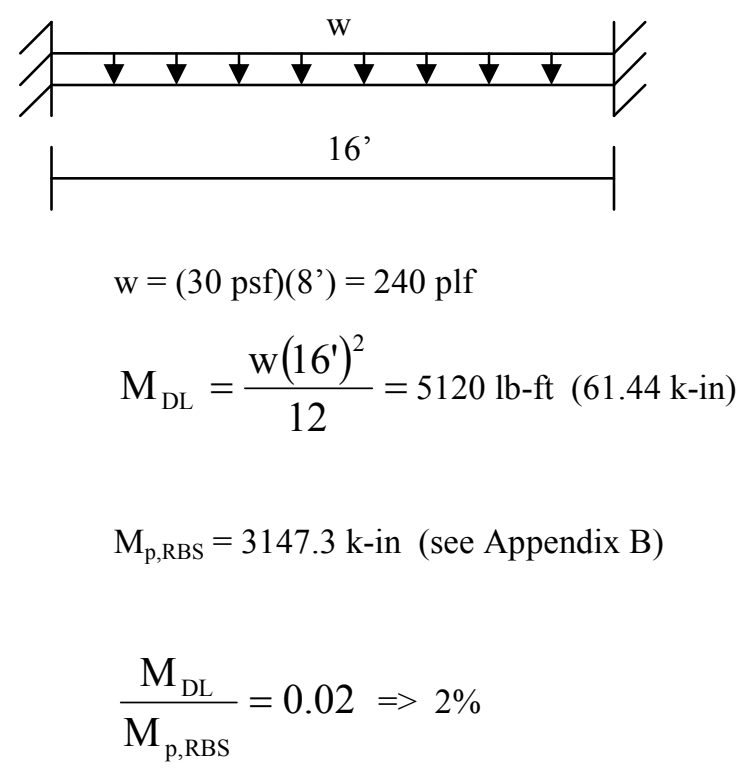




\section{Comparison of $\mathrm{M}_{\mathrm{DL}}$ to $\mathrm{M}_{\mathrm{p}, \mathrm{RBS}}=$ Floor (W21x57)}

$$
\begin{aligned}
& \mathrm{M}_{\mathrm{DL}}=\frac{\mathrm{w}\left(16^{\prime}\right)^{2}}{12}=6826.7 \mathrm{lb} \text {-ft }(81.9 \mathrm{k} \text {-in) } \\
& \mathrm{M}_{\mathrm{p}, \mathrm{RBS}}=5020.2 \mathrm{k} \text {-in (see Appendix B) } \\
& \frac{\mathrm{M}_{\mathrm{DL}}}{\mathrm{M}_{\mathrm{p}, \mathrm{RBS}}}=0.02 \Rightarrow 2 \%
\end{aligned}
$$




\section{APPENDIX D}

Strong Column / Weak Beam Check 
Comparison of $M_{p, c o l} \underline{\text { to } M_{p, R B S}}=$

$$
\begin{aligned}
& \mathrm{M}_{\mathrm{p}, \mathrm{col}}=\Phi \mathrm{F}_{\mathrm{y}} \mathrm{Z}_{\mathrm{x}}=(0.9)(50 \mathrm{ksi})\left(130 \mathrm{in}^{3}\right)=5850 \mathrm{k} \text {-in } \\
& \mathrm{M}_{\mathrm{p}, \mathrm{RBS}}=3147.3 \mathrm{k} \text {-in (see Appendix B) } \\
& \frac{\mathrm{M}_{\mathrm{p}, \mathrm{RBS}}}{\mathrm{M}_{\mathrm{p}, \mathrm{col}}}=0.54<1.0 \Rightarrow \text { strong col } / \text { weak bm }
\end{aligned}
$$

\section{Comparison of $M_{\mathrm{p}, \text { col }} \underline{\text { to } \mathrm{M}_{\mathrm{p}, \mathrm{RBS}}-\text { Floor }(\mathrm{W} 21 \times 57)}$}

$$
\begin{aligned}
& \mathrm{M}_{\mathrm{p}, \mathrm{col}}=\Phi \mathrm{F}_{\mathrm{y}} \mathrm{Z}_{\mathrm{x}}=(0.9)(50 \mathrm{ksi})\left(130 \mathrm{in}^{3}\right)=5850 \mathrm{k} \text {-in } \\
& \mathrm{M}_{\mathrm{p}, \mathrm{RBS}}=5020.2 \mathrm{k} \text {-in (see Appendix B) } \\
& \frac{\mathrm{M}_{\mathrm{p}, \mathrm{RBS}}}{\mathrm{M}_{\mathrm{p}, \mathrm{col}}}=0.86<1.0 \Rightarrow \text { strong col } / \text { weak bm }
\end{aligned}
$$




\section{APPENDIX E}

RISA Model Output 


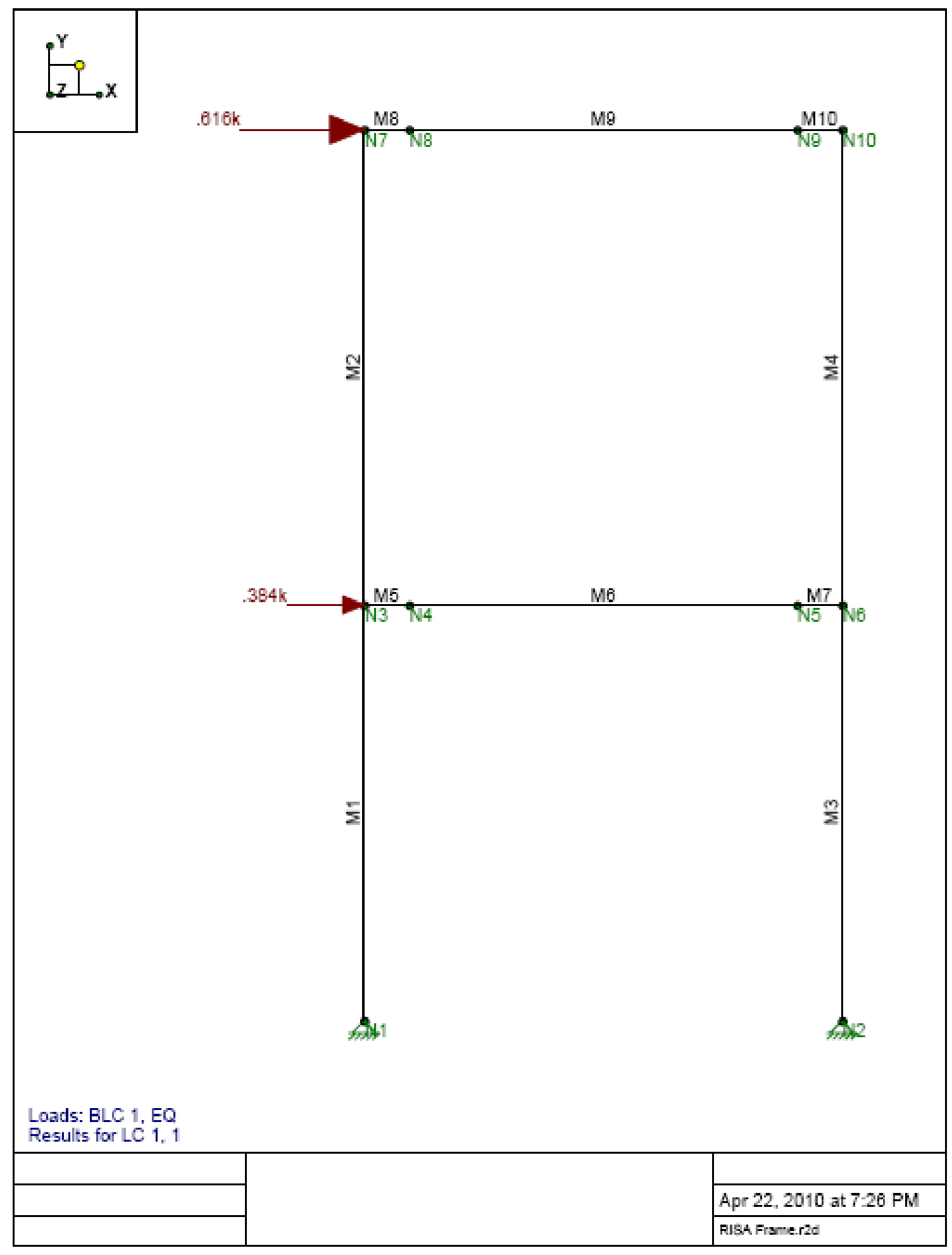




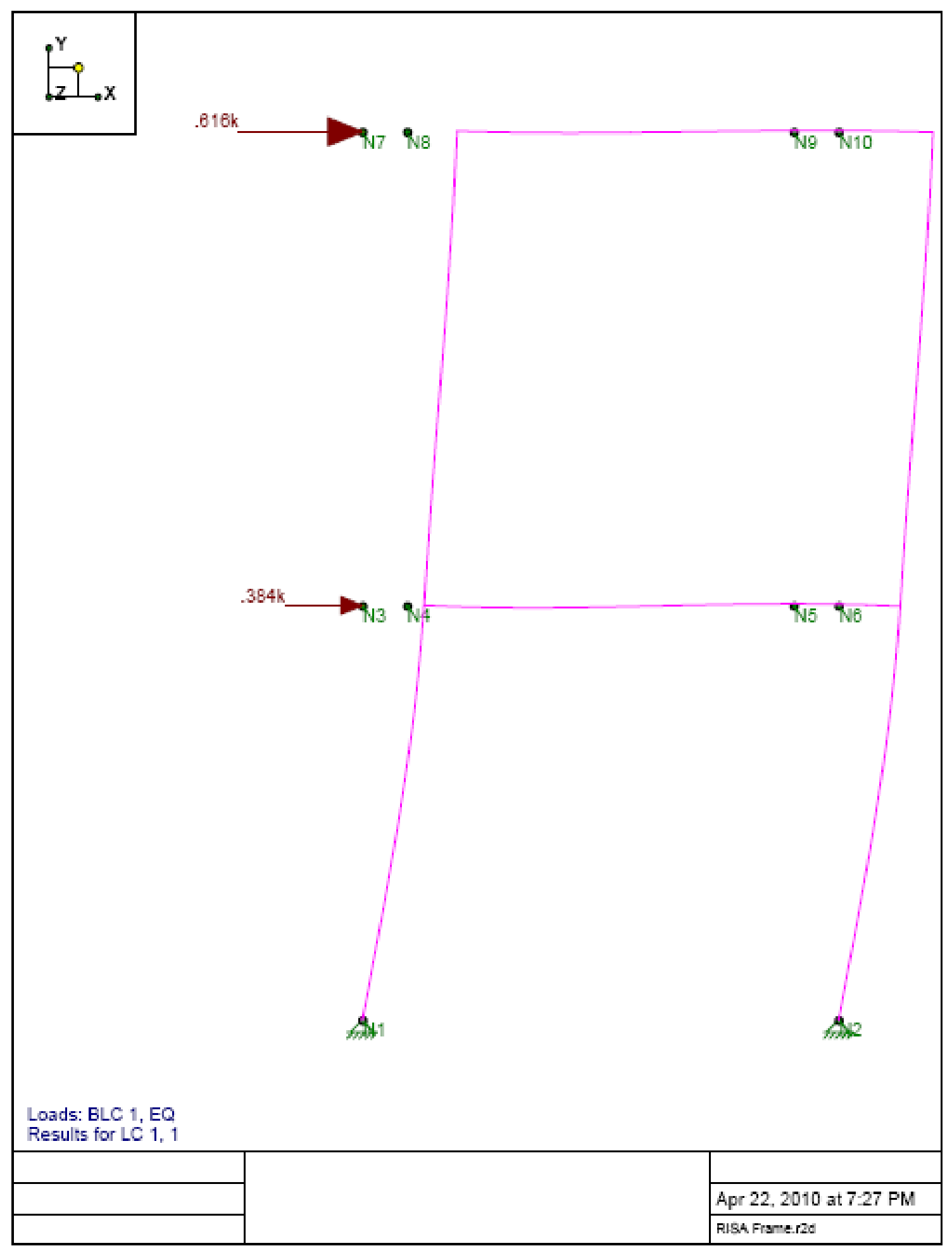




\begin{tabular}{ll} 
Company $\vdots$ & May 6,2010 \\
Designer & $7: 24$ PM \\
Job flumber : & Checked By. \\
\hline \hline
\end{tabular}

\section{Hot Rolled Steel Section Sets}

\begin{tabular}{|c|c|c|c|c|c|c|c|c|}
\hline & label & atags: & Tyre & Drsian Liat. & Deeign Guvea & $A \ln 21$ & 0.27020. & \\
\hline 1 & Column & $W 16 \times 67$ & Column & \begin{tabular}{|l|l|} 
Wide Flange & A72 Gr.50 \\
\end{tabular} & Tyoical & 18.7 & 119 & 854 \\
\hline 2 & Floor Beam & $W / 21 \times 57$ & Beam & Wide F ange $A 572$ Gr 50 & Troical & 16.7 & 30.6 & 1170 \\
\hline 3 & RocitBeam & $W 16 \times 45$ & Beam & Wide F ange $\$ 572$ Gr.50 & Tyoical & 133 & 328 & 586 \\
\hline
\end{tabular}

\section{Hot Rolled Steel Design Parameters}

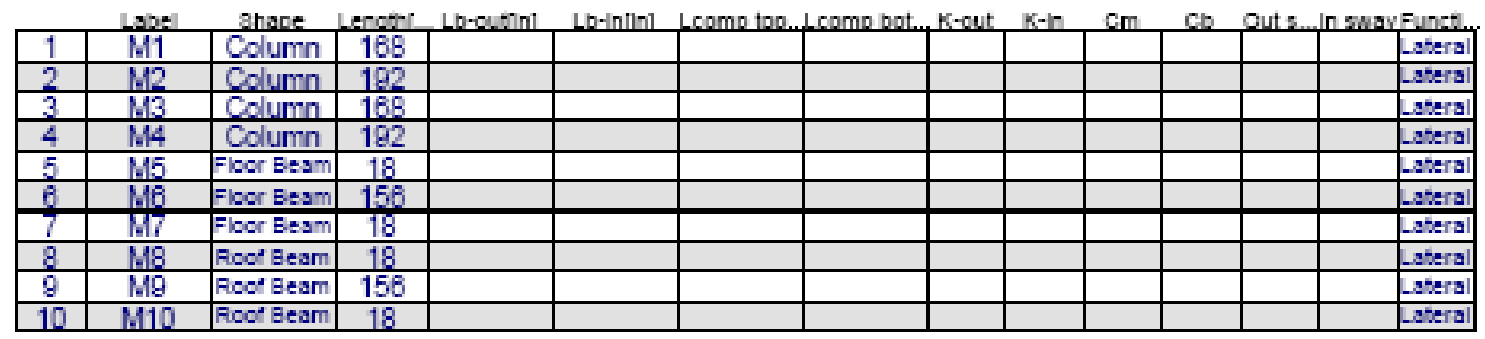

\section{Joint Coordinates and Temperatures}

\begin{tabular}{|c|c|c|c|c|}
\hline & Label & $x \cap n$ & Y Inn] & Temo IF] \\
\hline 1 & N1 & 0 & 0 & 0 \\
\hline 2 & N2 & 192 & 0 & 0 \\
\hline 3 & $\sqrt{3}$ & 0 & 168 & 0 \\
\hline 4 & 14 & 18 & 168 & 0 \\
\hline 5 & N5 & 174 & 168 & 0 \\
\hline B & N6 & 192 & 168 & 0 \\
\hline 7 & N7 & 0 & 360 & 0 \\
\hline 8 & N8 & 18 & 360 & 0 \\
\hline 8 & $\mathrm{Ng}$ & 174 & 360 & 0 \\
\hline 10 & N10 & 192 & 360 & 0 \\
\hline
\end{tabular}

\section{Member Primary Data}

\begin{tabular}{|c|c|c|c|c|c|c|c|c|c|}
\hline & Label & $1 \mathrm{Joint}$ & J Joint & Rotate (ds: g) & Baction/ghape & Type & Dealgn Lat & Materis| & Design Rules \\
\hline 1 & $\mathrm{M} 1$ & $\mathrm{N1}$ & $\mathrm{N} 3$ & & Column & Column & Wide Flanoe & A572 Gr.50 & Troical \\
\hline 2 & $1 \mathrm{M} 2$ & N3 & N7 & & Column & Column & Wide Flanoe & A.572 Gr.50 & Troical \\
\hline 3 & M3 & $\mathrm{N} 2$ & N6 & & Column & Column & Wide Flange & A.572 Gr.50 & Typical \\
\hline 4 & N4 & N8 & N10 & & Column & Column & Wide Flanoe & A572 Gr.50 & Ivoical \\
\hline 5 & N5 & $\sqrt{3}$ & $\mathrm{N4}$ & & Floor Beam & Beam & Wide Flanoe & A.572 Gr.50 & voical. \\
\hline 6 & Mo & N4 & N5 & & Floor Beam & Beam & Wide Flange & A.572 Gr.50 & Typical \\
\hline 7 & $M 7$ & N5 & N6 & & Fleor Beam & Beam & Wide Flanoe & A.572 Gr.50 & Troical \\
\hline 8 & M8 & N7 & NB & & Roof Beam & Beam & Wide Flange & A.572 Gr.50 & Typical \\
\hline 9 & M9 & NB & NP & & Rociseam & Beam & Wide Flanoe & A.572 Gr.50 & Troical. \\
\hline 10 & 1910 & NQ & N10 & & Roof Beam & Beam & Wide Flanoe & A.572 Gr.50 & Tyoical. \\
\hline
\end{tabular}

\section{Joint Boundary Conditions}

\begin{tabular}{|c|c|c|c|c|c|}
\hline & oint labes: & $x$ nolni & Y nolnt & Rotationit-ftirach & Footing \\
\hline 1 & $\mathrm{N1}$ & Reaction & Reaction & & \\
\hline 2 & $\mathrm{~N} 2$ & Reaction & Reaction & & \\
\hline
\end{tabular}

\footnotetext{
RISA-2D Version 9.0.0 $\quad$ [C.t...Imknutsen/DesktoplThesis/CalcsiRisal201004221FramelRISA Frame.r20] Page 1
} 


\begin{tabular}{ll} 
Company $\vdots$ & May 6,2010 \\
Designer & $7: 24$ PM \\
Job Rumber : & Checked By. \\
\hline
\end{tabular}

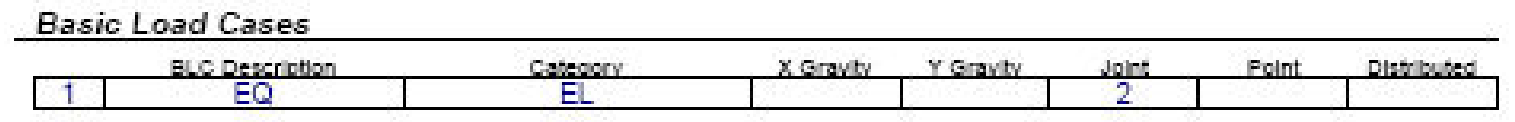

Joint Loads and Enforced Displacements (BLC 1: EQ)

\begin{tabular}{|c|c|c|c|c|}
\hline & getlabel & $-2 . \mathrm{M}$ & Direction & 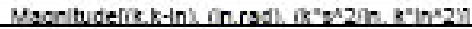 \\
\hline 1 & $\mathrm{~N} 3$ & $\mathrm{~L}$ & $\mathrm{X}$ & 384 \\
\hline 2 & N7 & $\overline{\mathrm{L}}$ & $\bar{x}$ & 816 \\
\hline
\end{tabular}

\section{Load Combinations}

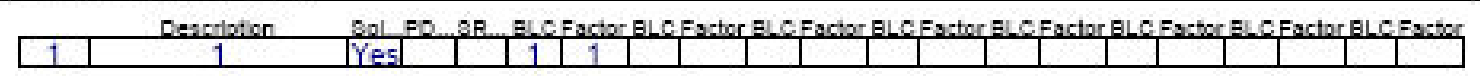

\begin{tabular}{|c|c|c|c|c|c|}
\hline & 10 & Joirt label & $x \ln 1$ & Y $\mathrm{nn}$ & Fotstion inger \\
\hline 1 & 1 & $\mathrm{~N} 1$ & 0 & 0 & $-3.741 e-4$ \\
\hline 2 & 1 & $\mathrm{~N} 2$ & 0 & 0 & $-3.736 \mathrm{e} 4$ \\
\hline 3 & 1 & $\mathrm{~N} 3$ & .5 & 0 & $-1.19 e-4$ \\
\hline 4 & 1 & $\mathrm{N4}$ & .05 & 0 & $-6.714 e-5$ \\
\hline 5 & 1 & N5 & .05 & 0 & $-6.687 e 5$ \\
\hline 8 & 1 & N6 & .05 & 0 & $-1.187 e^{-4}$ \\
\hline 7 & 1 & N7 & 076 & 0 & $-789 e-5$ \\
\hline 8 & 1 & NB & 078 & 0 & $4.494=5$ \\
\hline 9 & 1 & N9 & .078 & 0 & $-4.467 \mathrm{e}-5$ \\
\hline 10 & 1 & N10 & 076 & D & $-7.857 e 5$ \\
\hline
\end{tabular}

\section{Joint Reactions}

\begin{tabular}{|c|c|c|c|c|c|}
\hline & 10 & Jon:that & $x \mathrm{ma}$ & $Y \mathrm{ma}$ & $M z=n=n+1$ \\
\hline 1 & 1 & N1 & -5 & -1.491 & 0 \\
\hline 2 & 1 & $\mathrm{~N} 2$ & -.5 & 1.481 & 0 \\
\hline 3 & 1 & Totals: & -1 & 0 & \\
\hline 4 & 1 & $\operatorname{Cog}$ (in) & $\mathrm{NC}$ & $\mathrm{NC}$ & \\
\hline
\end{tabular}

\section{Member Section Forces}

\begin{tabular}{|c|c|c|c|c|c|c|}
\hline & عـ ع & Mermber ways: & ses & Avialot & ahearki & Momentik-n! \\
\hline 1 & 1 & M1 & 1 & -1.491 & .5 & 0 \\
\hline 2 & & & 2 & -1.491 & 5 & -21.007 \\
\hline 3 & & & 3 & -1.491 & 5 & -42.015 \\
\hline 4 & & & 4 & -1.491 & .5 & -63.022 \\
\hline 5 & & & 5 & -1.491 & 5 & -84.03 \\
\hline 6 & 1 & $\overline{M 2}$ & 1 & -368 & 308 & 23.819 \\
\hline 7 & & & 2 & -388 & $30 B$ & 9.021 \\
\hline$\frac{1}{8}$ & & & 3 & -388 & 308 & 5.778 \\
\hline 9 & & & 4 & -368 & 308 & -20.576 \\
\hline 10 & & & 5 & -368 & 308 & -35.374 \\
\hline 11 & 1 & $\overline{M 3}$ & 1 & 1.491 & .5 & 0 \\
\hline 12 & & & 2 & 1491 & 5 & -20.993 \\
\hline 13 & & & 3 & 1491 & 5 & -41985 \\
\hline 14 & & & 4 & 1.491 & .5 & -62.978 \\
\hline 15 & & & 5 & 1491 & 5 & -83.97 \\
\hline 16 & 1 & $\overline{M 4}$ & 1 & 368 & 308 & 23762 \\
\hline
\end{tabular}

RISA-20 Version 9.0.0 [C.t...imknutsen/Desktop/Thesis/Calcs|Risal20100422.FramelRISA Frame.r20] Page 2 


\begin{tabular}{ll} 
Company $\vdots$ & May 6,2010 \\
Designer & $7: 24$ PM \\
Job Number : & Checked By. \\
\hline \hline
\end{tabular}

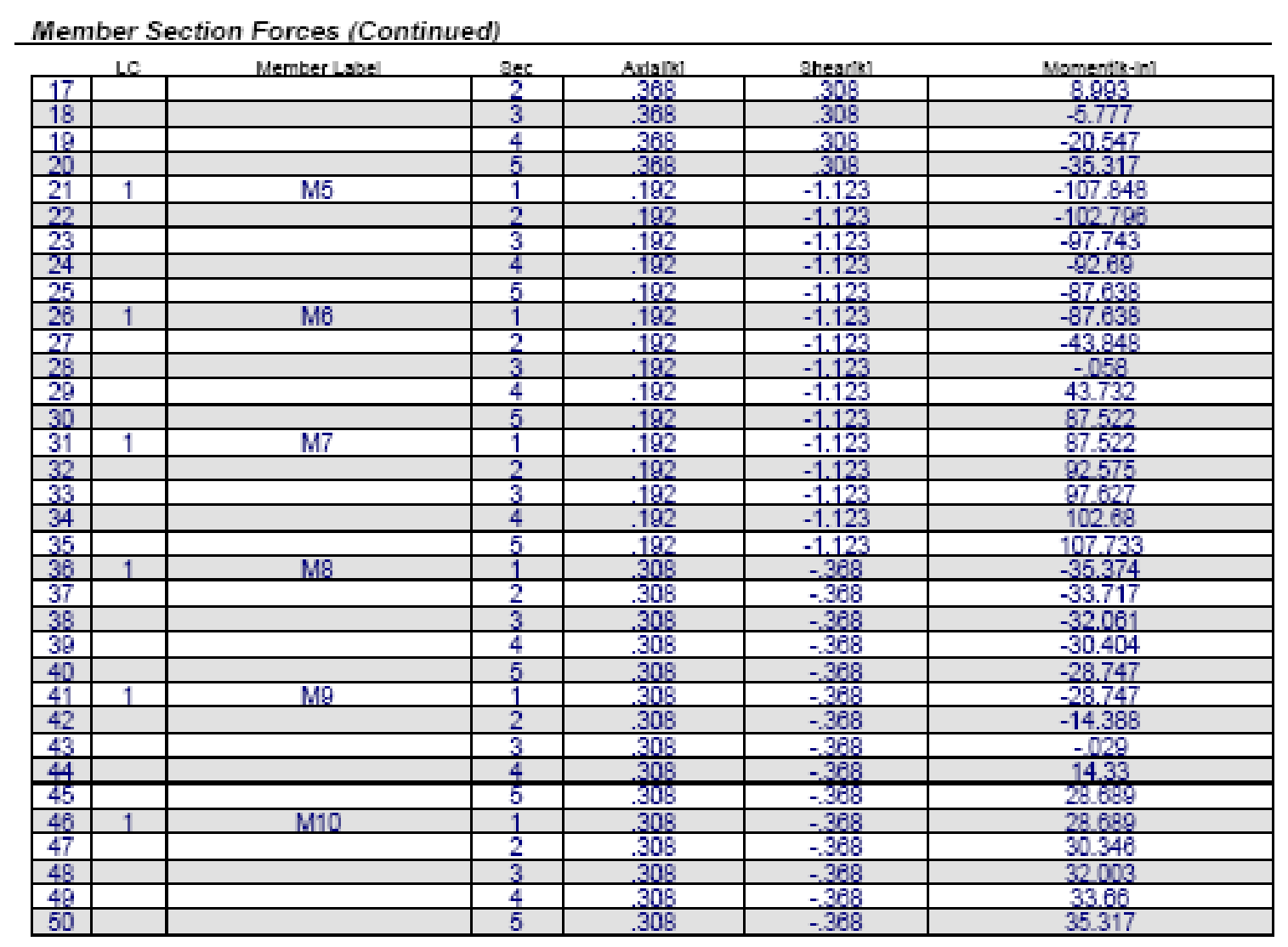




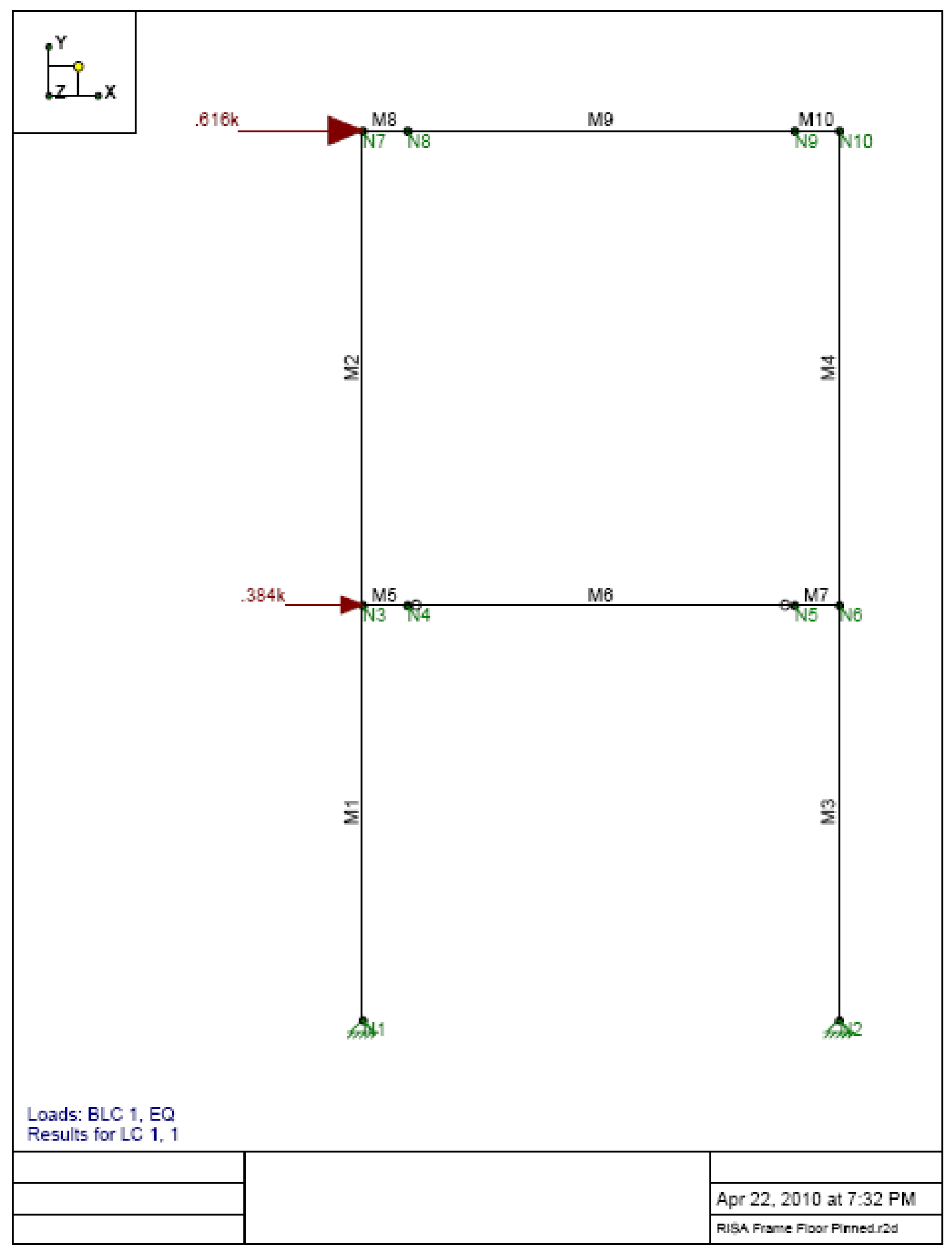




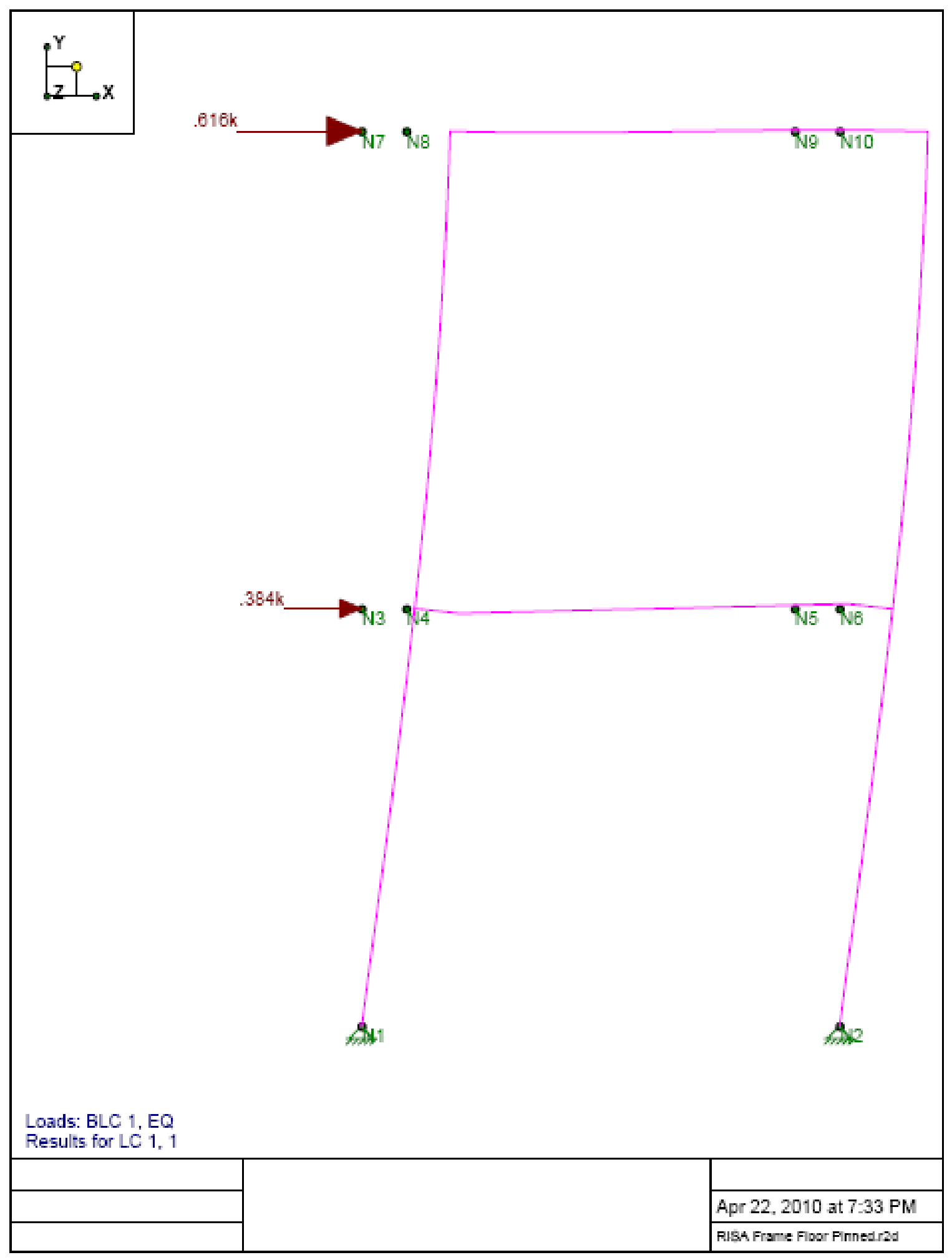


Company :

May 6.2010

Job Niumber:

Hot Rolled Steel Section Sets

\begin{tabular}{|c|c|c|c|c|c|c|c|c|}
\hline & ئ & 8 & Tyr & Dosian & Dea & $A \ln 21$ & a. & \\
\hline 1 & Column & $W 16 \times 67$ & Column & \begin{tabular}{|l|l|} 
Wide Flange & A52 Gr.50 \\
\end{tabular} & Typical & 18.7 & 119 & 854 \\
\hline 2 & Floor Beam & $W 21 \times 57$ & Beam & Wide F anae $A 572$ Gr. 50 & Troical & 16.7 & 30.6 & 1170 \\
\hline 3 & Reci Beam & $W 16 \times 45$ & Beam & Wide Flange $A 572$ Gr.50 & Troical & 133 & 328 & 586 \\
\hline
\end{tabular}

\section{Hot Rolled Steel Design Parameters}

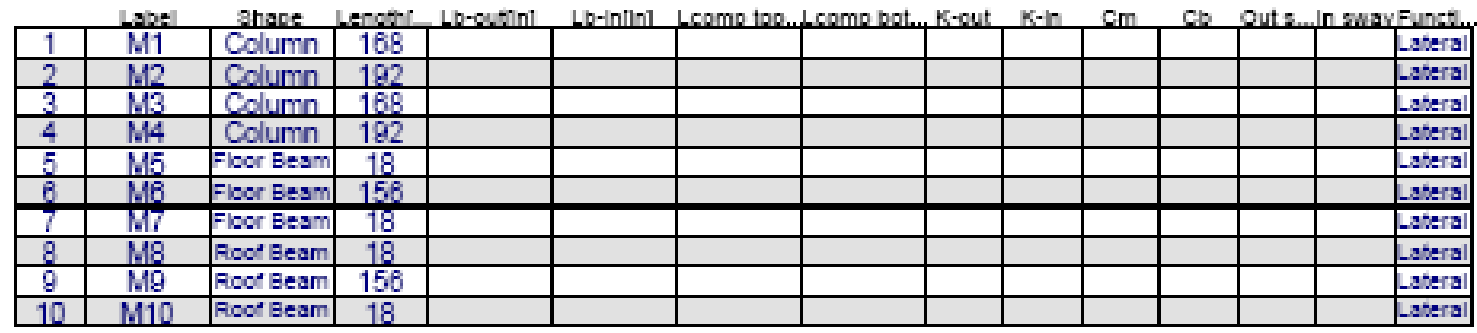

Joint Coordinates and Temperatures

\begin{tabular}{|c|c|c|c|c|}
\hline & Labed & $x: n$ & $Y \ln ]$ & Temo[F] \\
\hline 1 & N1 & 0 & 0 & 0 \\
\hline 2 & N2 & 192 & 0 & 0 \\
\hline 3 & $\mathrm{N3}$ & 0 & 168 & 0 \\
\hline 4 & N4 & 18 & 168 & 0 \\
\hline 5 & N5 & 174 & 168 & 0 \\
\hline 6 & N6 & 192 & 168 & 0 \\
\hline 7 & N7 & 0 & 360 & 0 \\
\hline 8 & $\mathrm{NB}$ & 18 & 360 & 0 \\
\hline 8 & NQ & 174 & 360 & 0 \\
\hline 10 & N10 & 192 & 360 & 0 \\
\hline
\end{tabular}

\section{Member Primary Data}

\begin{tabular}{|c|c|c|c|c|c|c|c|c|c|}
\hline & Label & $1 \mathrm{Jg}$ int & J Joint & Rotateids?) & Baction/ghape & Type & Desipn Last & Mat:er|al & Design Rules \\
\hline 3 & $\mathrm{M} 3$ & $\sqrt{2}$ & N6 & & Column & Column & Wide Flange & A572 Gr.50 & Yyoical \\
\hline 5 & 115 & $\sqrt{3}$ & $\mathrm{N4}$ & & Floor Beam & Beam & Wide Flanoe & A.572 Gr.50 & Troical \\
\hline 8 & MB & $\mathrm{N4}$ & N5 & & Floor Beam & Beam & Wide Flange & A572 Gr.50 & Typical \\
\hline 7 & $M 7$ & $\mathrm{N5}$ & N6 & & Floor Beam & Beam & Wide Flanoe & A572 Gr.50 & Tucical \\
\hline 10 & $\mathrm{M10}$ & $\mathrm{NQ}$ & N10 & & Roof Beam & Beam & Wide Flanoe & A.572 Gr.50 & Tyoical \\
\hline
\end{tabular}

Joint Boundary Conditions

\begin{tabular}{|c|c|c|c|c|c|}
\hline & gintlupes: & $x \mathrm{nani}$ & Y inlni & Potationitk-ftirad & Footing \\
\hline 1 & N1 & Reaction & Reaction & & \\
\hline 2 & $\sqrt{2}$ & Reaction & Reaction & & \\
\hline
\end{tabular}

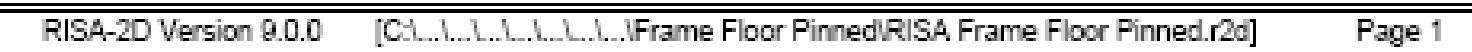


Basic Load Cases

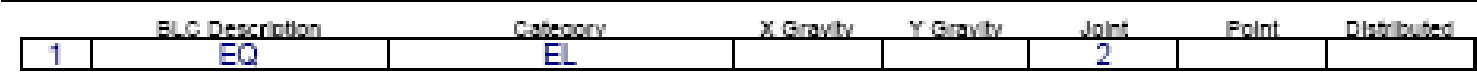

Joint Loads and Enforced Displacements (BLC $1: E Q)$

\begin{tabular}{|c|c|c|c|c|}
\hline & inthabe & L.M.M. & Direction & 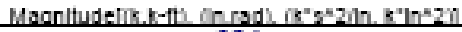 \\
\hline 1 & N3 & L & $\mathrm{X}$ & 384 \\
\hline 2 & $\mathrm{N7}$ & L & $\bar{X}$ & 616 \\
\hline
\end{tabular}

\section{Load Combinations}

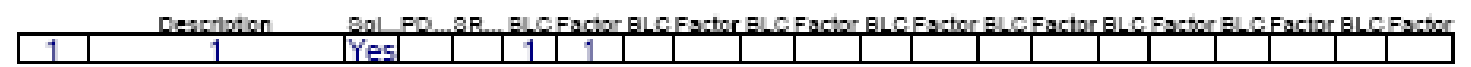

\section{Joint Deflections}

\begin{tabular}{|c|c|c|c|c|c|}
\hline & Le. & Jolnthabel & $x \ln 1$ & Ynn] & Fotation insell \\
\hline 1 & 1 & N1 & 0 & 0 & $-1.348 e-3$ \\
\hline 2 & 1 & N2 & 0 & 0 & $-1.348 \mathrm{e}-3$ \\
\hline 3 & 1 & $\mathrm{N3}$ & 214 & 0 & $-1.093 e^{3}$ \\
\hline 4 & 1 & $\mathrm{N4}$ & .214 & -.018 & $-1.093 e-3$ \\
\hline 5 & 1 & N5 & 213 & 019 & $-1.093+3$ \\
\hline 6 & 1 & N6 & 213 & 0 & $-1.093 e-3$ \\
\hline 7 & 1 & N7 & 355 & 0 & $-3.051 e^{4}$ \\
\hline 8 & 1 & NB & 355 & -.003 & $-1.676 \mathrm{e}-4$ \\
\hline 8 & 1 & NO & 355 & .003 & $-1.674 e^{-4}$ \\
\hline 10 & 1 & $\mathrm{N10}$ & 355 & 0 & $-3.048 e-4$ \\
\hline
\end{tabular}

\section{Joint Reactions}

\begin{tabular}{|c|c|c|c|c|c|}
\hline & 10 & Jointlabe: & $x \mathrm{ma}$ & $Y \mathrm{~m}$ & $M \geq n \rightarrow 1$ \\
\hline 1 & 1 & $\mathrm{~N} 1$ & -5 & -1.491 & 0 \\
\hline 2 & 1 & N2 & -5 & 1.491 & 0 \\
\hline 3 & 1 & Totals: & -1 & 0 & \\
\hline 4 & 1 & $\mathrm{COG}$ (in) & $\mathrm{NC}$ & $\mathrm{NC}$ & \\
\hline
\end{tabular}

\section{Member Section Forces}

\begin{tabular}{|c|c|c|c|c|c|c|}
\hline & Le & Member Labs: & sec & Axlalk1 & ahear"k? & Momentikn-ft \\
\hline 1 & 1 & $M 1$ & 1 & -1.491 & .5 & 0 \\
\hline 2 & & & 2 & -1.491 & 5 & -1.75 \\
\hline 3 & & & 3 & -1.491 & 5 & -35 \\
\hline 4 & & & 4 & -1.491 & .5 & -5.25 \\
\hline 5 & & & 5 & -1.491 & 5 & -7 \\
\hline 6 & 1 & $M 2$ & 1 & -1.491 & 308 & -7 \\
\hline 7 & & & 2 & -1.491 & 308 & -8.233 \\
\hline 8 & & & 3 & -1.491 & 308 & -9.465 \\
\hline 9 & & & 4 & -1.491 & 308 & -10.698 \\
\hline 10 & & & 5 & -1.491 & 308 & -11.93 \\
\hline 11 & 1 & $M 3$ & 1 & 1.491 & .5 & 0 \\
\hline 12 & & & 2 & 1.491 & 5 & -175 \\
\hline 13 & & & 3 & 1.491 & 5 & -3.5 \\
\hline 14 & & & 4 & 1.491 & .5 & -5.25 \\
\hline 15 & & & 5 & 1.491 & 5 & -7 \\
\hline 16 & 1 & 194 & 1 & 1.491 & 308 & -7 \\
\hline
\end{tabular}




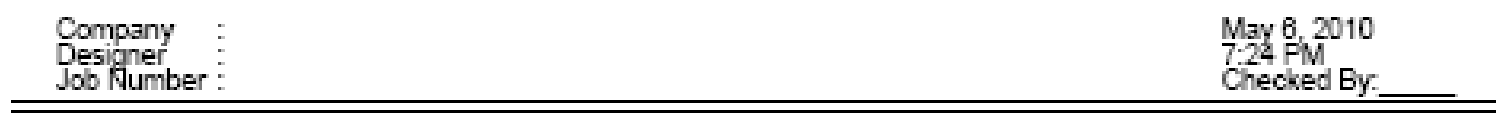

\begin{tabular}{|c|c|c|c|c|c|c|}
\hline & عـا & Member Lave: & 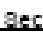 & Arlalk1. & aheark" & Mamentik-tt \\
\hline 17 & & & 2 & 1491 & 308 & -8.231 \\
\hline 18 & & & 3 & 1.491 & 308 & -9.483 \\
\hline 19 & & & 4 & 1.491 & 308 & $-10,694$ \\
\hline 20 & & & 5 & 1491 & 308 & -11.926 \\
\hline 21 & 1 & $M 5$ & 1 & .192 & 0 & 0 \\
\hline 22 & & & 2 & 192 & 0 & 0 \\
\hline 23 & & & 3 & .192 & 0 & 0 \\
\hline 24 & & & $\frac{1}{4}$ & .182 & 0 & 0 \\
\hline 25 & & & 5 & 192 & 0 & $\overline{0}$ \\
\hline 26 & 1 & $\overline{M 6}$ & 1 & .192 & 0 & 0 \\
\hline 27 & & & 2 & 192 & 0 & 0 \\
\hline 28 & & & 3 & 192 & 0 & 0 \\
\hline 29 & & & 4 & .192 & 0 & 0 \\
\hline 30 & & & 5 & 192 & 0 & 0 \\
\hline 31 & 1 & M7 & 1 & .192 & 0 & 0 \\
\hline 32 & & & 2 & 192 & 0 & 0 \\
\hline 33 & & & 3 & 192 & 0 & 0 \\
\hline 34 & & & 4 & .192 & 0 & 0 \\
\hline 35 & & & 5 & 192 & 0 & 0 \\
\hline 36 & 1 & $\overline{188}$ & 1 & 308 & -1.491 & -11.93 \\
\hline 37 & & & 2 & 308 & -1.491 & -11.371 \\
\hline 38 & & & 3 & 308 & -1.491 & -10.812 \\
\hline $3 \theta$ & & & 4 & 308 & -1.491 & -10.253 \\
\hline 40 & & & 5 & 308 & -1.491 & -9.604 \\
\hline 41 & 1 & 199 & 1 & 308 & -1.491 & -9604 \\
\hline 42 & & & 2 & 308 & -1.491 & 4.848 \\
\hline 43 & & & 3 & 308 & $-1,491$ & -0.02 \\
\hline 44 & & & 4 & 308 & -1.491 & 4.844 \\
\hline 45 & & & 5 & 308 & -1.491 & 9.689 \\
\hline 48 & 1 & M10 & 1 & 308 & -1.491 & 9.689 \\
\hline 47 & & & $\frac{1}{2}$ & 308 & -1.491 & 10.249 \\
\hline 48 & & & 3 & 308 & -1.491 & 10.808 \\
\hline 49 & & & 4 & 308 & -1.491 & 11.387 \\
\hline 50 & & & 5 & .308 & -1.491 & 11.826 \\
\hline
\end{tabular}

RISA-2D Version 9.0.0 [C.L..1...L.........L......IFrame Floor PinnedIRISA Frame Floor Pinned.r2o] $\quad$ Page 3 


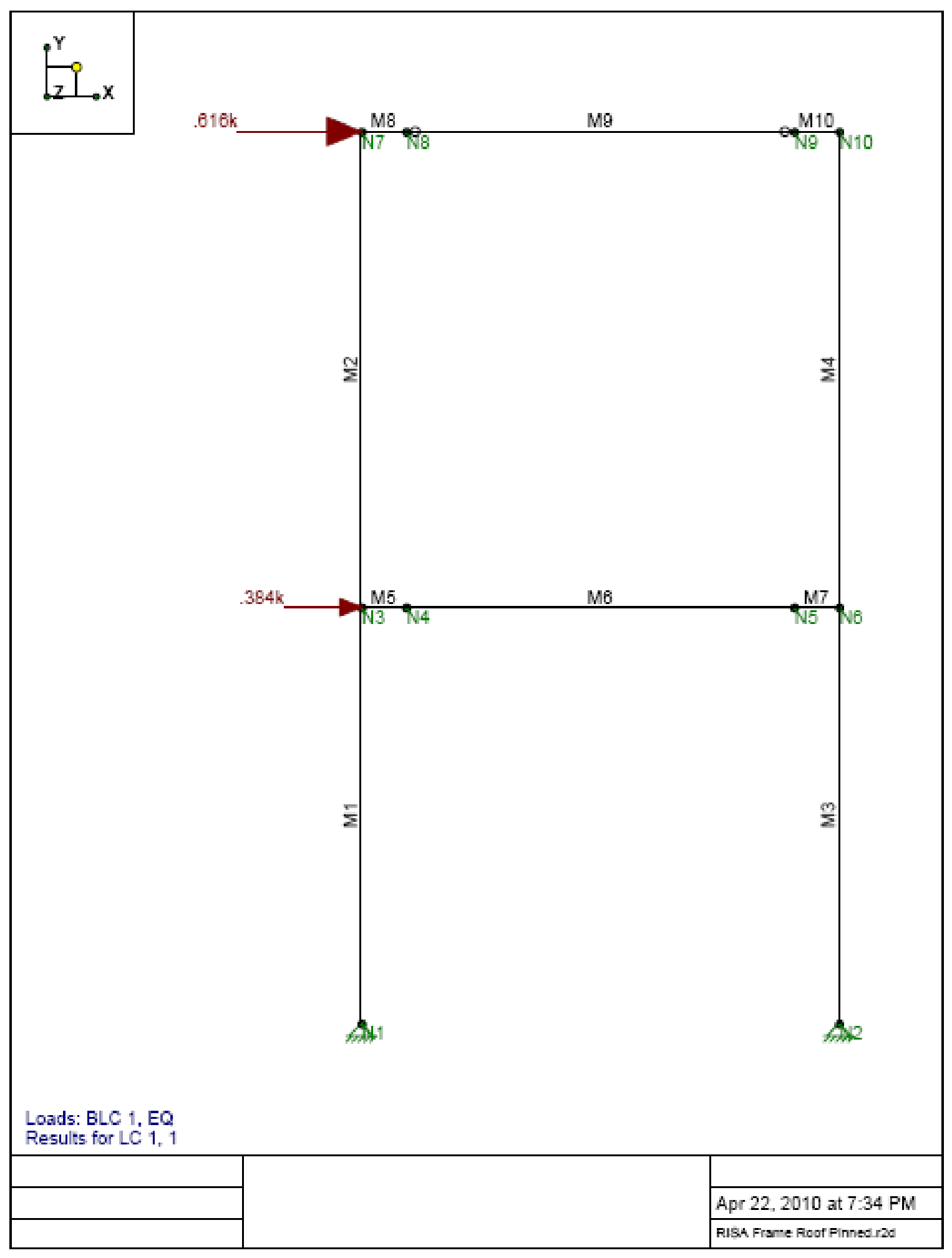




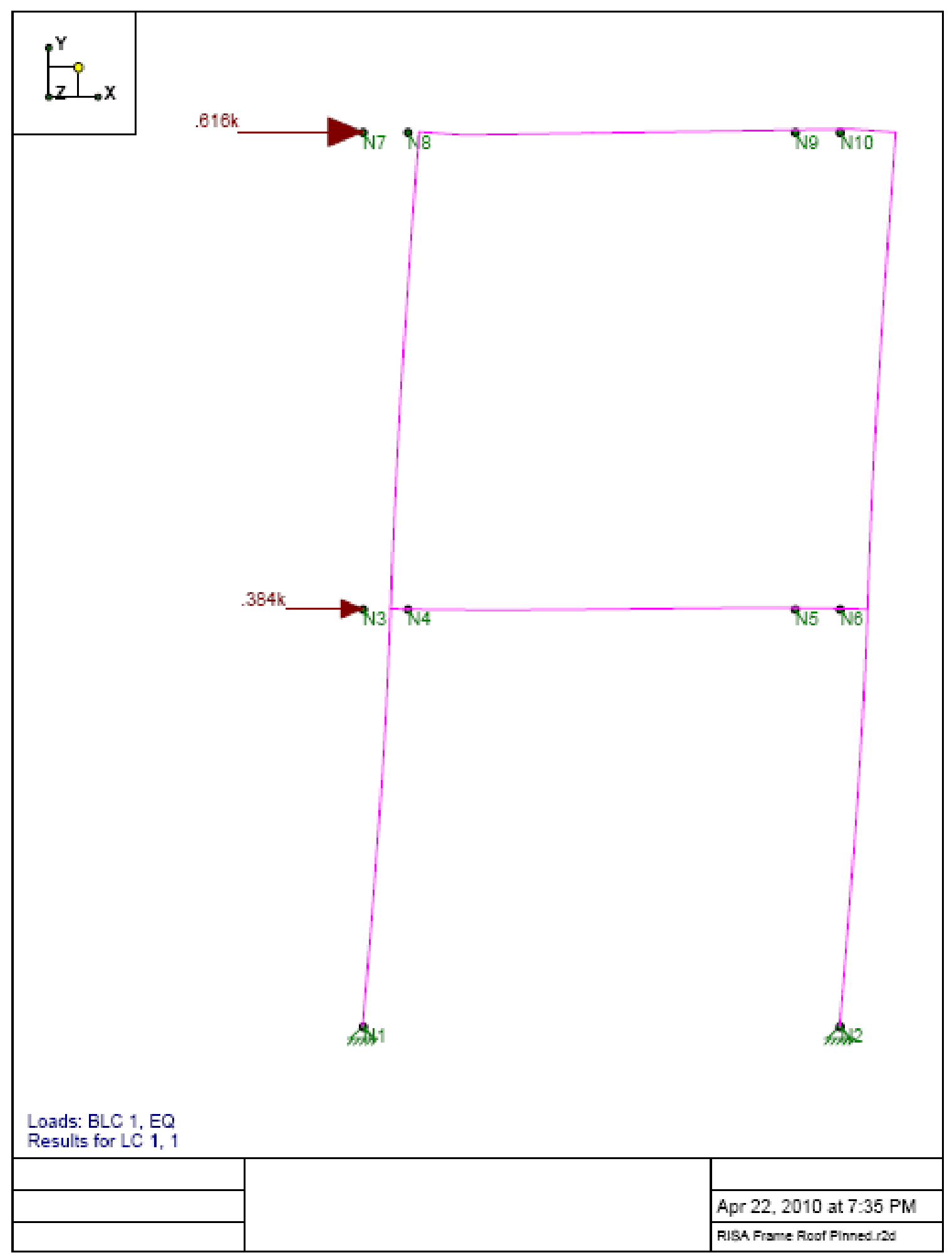




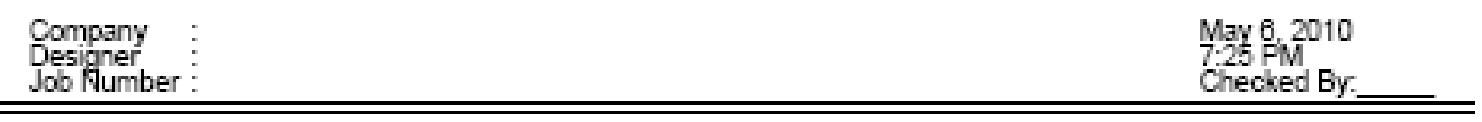

Hot Rolled Steel Section Sets

\begin{tabular}{|c|c|c|c|c|c|c|c|c|}
\hline & & & Tyoe & & & $A \ln 21$ & & \\
\hline 1 & Column & W16 $\times 67$ & Column & Wide Flange $A .572$ Gr.50 & Typical & 18.7 & 119 & 854 \\
\hline 2 & Floor Beam & $W 21 \times 57$ & Beam & Wide Flange $A 572 \mathrm{Gr} 50$ & Tyoical. & 16.7 & 30.6 & 1170 \\
\hline 3 & Roof Beam & $W 16 \times 45$ & Beam & Wide Flangel A572 Gr.50 & Tyoical. & 133 & 328 & 586 \\
\hline
\end{tabular}

\section{Hot Rolled Steel Design Parameters}

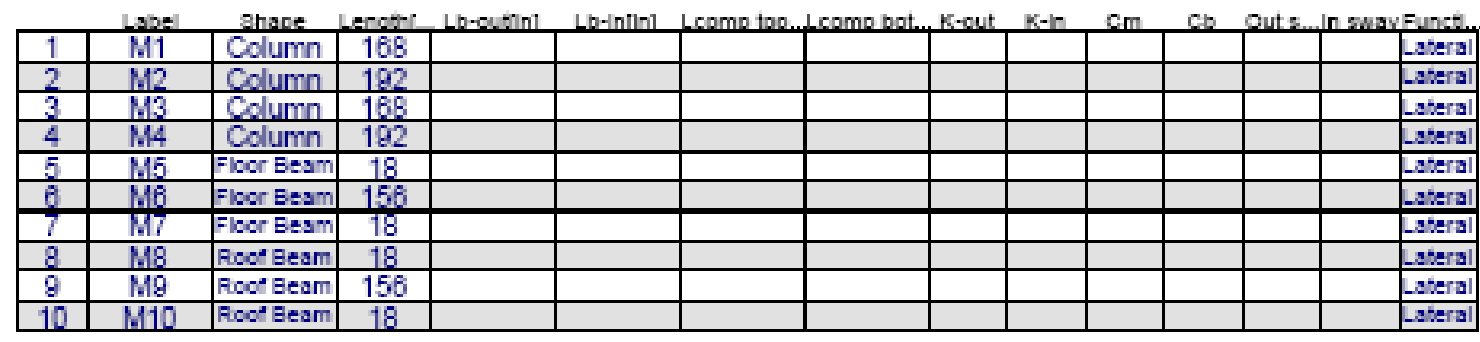

\begin{tabular}{|c|c|c|c|c|}
\hline & Latafel & $x \min$ & $Y[\ln 1]$ & $T=m_{0}$ IFI \\
\hline \begin{tabular}{|l|}
1 \\
0
\end{tabular} & N1 & 0 & 0 & 0 \\
\hline & $\mathrm{N} 2$ & 192 & 0 & 0 \\
\hline 5 & $\mathrm{~N} 3$ & & 168 & 0 \\
\hline 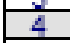 & 114 & 18 & 168 & 0 \\
\hline 5 & N5 & 174 & 168 & 0 \\
\hline \begin{tabular}{|l|l}
6 \\
\end{tabular} & NB & 192 & 168 & 0 \\
\hline \begin{tabular}{|l|}
7 \\
\end{tabular} & N7 & 0 & 360 & 0 \\
\hline \begin{tabular}{|l|}
8 \\
\end{tabular} & N8 & 18 & 360 & 0 \\
\hline 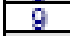 & N9 & 174 & 300 & 0 \\
\hline \begin{tabular}{|l|l}
10 \\
\end{tabular} & N10 & 192 & 300 & 0 \\
\hline
\end{tabular}

\section{Member Primary Data}

\begin{tabular}{|c|c|c|c|c|c|c|c|c|c|}
\hline & Label & I Joint & J Jont & Rotate (ds? & Secton/Ohape & Type & Dealzn Last & Material & Design Rule: \\
\hline 1 & $\mathrm{M} 1$ & $\mathrm{N1}$ & $\mathrm{N} 3$ & & Column & Column & Wide Flanoe & A572 Gr.50 & Troical \\
\hline 2 & $\mathrm{M} 2$ & $\mathrm{N3}$ & $\mathrm{N7}$ & & column & Column & Wide Flange & A $572 \mathrm{Gr} .50$ & Tyoical \\
\hline 3 & $\mathrm{M} 3$ & $\mathrm{~N} 2$ & N6 & & Column & Column & Wide Flange & A.572 Gr.50 & Typical \\
\hline 4 & $\overline{M 4}$ & $\overline{\mathrm{N} 6}$ & N10 & & Column & Column & Wide Flanoe & A572 Gr.50 & Tyoical. \\
\hline 5 & N5 & $\sqrt{3}$ & $\mathrm{N4}$ & & Floor Beam & Beam & Wide Flanoe & A.572 Gr.50 & Troical \\
\hline 6 & Me & N4 & N5 & & Floor Beam & Beam & Wide Flange & A.572 Gr.50 & Typical \\
\hline 7 & M7 & $\mathrm{N5}$ & $\mathrm{NB}$ & & Floor Beam & Beam & Wide Flanoe & A572 Gr.50 & Troical \\
\hline 8 & M8 & N7 & NB & & Roof Beam & Beam & Wide Flange & A572 Gr.50 & Typical \\
\hline 9 & MQ & $\mathrm{NB}$ & $\mathrm{NQ}$ & & RoofBeam & Beam & Wide Flanoe & A572 Gr.50 & Troical \\
\hline 10 & M10 & $\mathrm{NQ}$ & N10 & & Roof Beam & Beam & Wide Flanoe & A572 Gr.50 & Tyoical \\
\hline
\end{tabular}

Joint Boundary Conditions

\begin{tabular}{|c|c|c|c|c|c|}
\hline \multicolumn{2}{|c|}{ Footne } \\
\hline 1 & $\mathrm{~N} 1$ & Reaction & Reaction & & \\
\hline 2 & $\mathrm{~N} 2$ & Reaction & Reaction & & \\
\hline
\end{tabular}

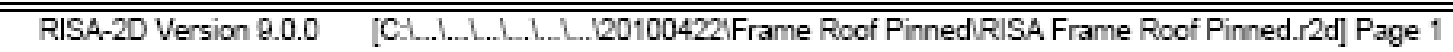




\begin{tabular}{ll} 
Company $\vdots$ & May 6.2010 \\
Designer & 725 PM \\
Job Fumber : & Checked By. \\
\hline \hline
\end{tabular}

Basic Load Cases

\begin{tabular}{|c|c|c|c|c|c|c|}
\hline & Buc Deparition & Gateocry & xGravty & Yoravity & Jalet & Dintributed \\
\hline 1 & $E Q$ & $\mathrm{EL}$ & & & 2 & \\
\hline
\end{tabular}

Joint Loads and Enforced Displacements (BLC 1: EQ)

\begin{tabular}{|c|c|c|c|c|}
\hline & intlabe: & L.M.M & Direction & 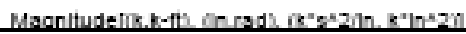 \\
\hline 1 & $\mathrm{~N} 3$ & $\mathrm{~L}$ & $\mathrm{X}$ & .384 \\
\hline 2 & N7 & $\bar{L}$ & $\bar{x}$ & 616 \\
\hline
\end{tabular}

\section{Load Combinations}

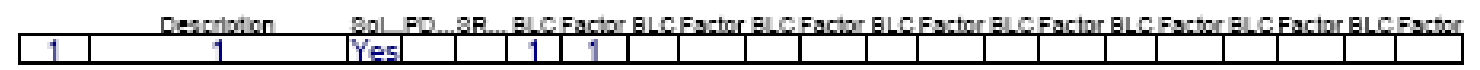

\section{Joint Deflections}

\begin{tabular}{|c|c|c|c|c|c|}
\hline & 10 & Jolnthal & $x \ln 1$ & $\mathrm{Ynn}$ & Botation insol] \\
\hline 2 & 1 & $\mathrm{N2}$ & 0 & 0 & $-4.111 e-4$ \\
\hline 3 & 1 & $\sqrt{3}$ & 0.6 & 0 & $-1.565 e-4$ \\
\hline 4 & 1 & $\mathrm{N4}$ & .056 & -.001 & $-8.761 e-5$ \\
\hline 5 & 1 & N5 & 056 & 001 & $-8.736 e-5$ \\
\hline 6 & 1 & N6 & .056 & 0 & $-1.561 e^{4}$ \\
\hline 7 & 1 & N7 & 113 & 0 & $-3.617 \mathrm{e}-4$ \\
\hline 10 & 1 & $\mathrm{N10}$ & 113 & 0 & $-3.613 e-4$ \\
\hline
\end{tabular}

\section{Joint Reactions}

\begin{tabular}{|c|c|c|c|c|c|}
\hline & $1 \mathrm{C}$ & 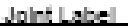 & $x \mathrm{~m}$ & $Y \mathrm{~m}$ & $M=x-1$ \\
\hline 1 & 1 & N1 & -5 & -1.491 & 0 \\
\hline 2 & 1 & $\mathrm{~N} 2$ & -5 & 1.491 & 0 \\
\hline 3 & 1 & Totals & -1 & 0 & \\
\hline 4 & 1 & $\mathrm{COG}$ (in): & $N C$ & $\mathrm{NC}$ & \\
\hline
\end{tabular}

\section{Member Section Forces}

\begin{tabular}{|c|c|c|c|c|c|c|}
\hline & LC & Member Labs: & sec & Axlalk1 & aheark? & Momenthk-th \\
\hline 1 & 1 & $M 1$ & 1 & -1.491 & .5 & 0 \\
\hline 2 & & & 2 & -1.491 & 5 & -1.751 \\
\hline 3 & & & 3 & -1491 & 5 & -3501 \\
\hline 4 & & & 4 & -1.491 & .5 & -5.252 \\
\hline 5 & & & 5 & -1.491 & 5 & $-7,003$ \\
\hline 6 & 1 & 192 & 1 & 0 & 308 & 4.93 \\
\hline 7 & & & 2 & 0 & 308 & 3.697 \\
\hline 8 & & & 3 & 0 & 308 & 2.465 \\
\hline 8 & & & 4 & 0 & 308 & 1.232 \\
\hline 10 & & & 5 & 0 & 308 & 0 \\
\hline 11 & 1 & 193 & 1 & 1.491 & .5 & 0 \\
\hline 12 & & & 2 & 1491 & 5 & -1.749 \\
\hline 13 & & & 3 & 1.491 & 5 & -3.498 \\
\hline 14 & & & 4 & 1.491 & .5 & 5.248 \\
\hline 15 & & & 5 & 1.491 & 5 & -6.897 \\
\hline 16 & 1 & 194 & 1 & 0 & 308 & 4926 \\
\hline
\end{tabular}




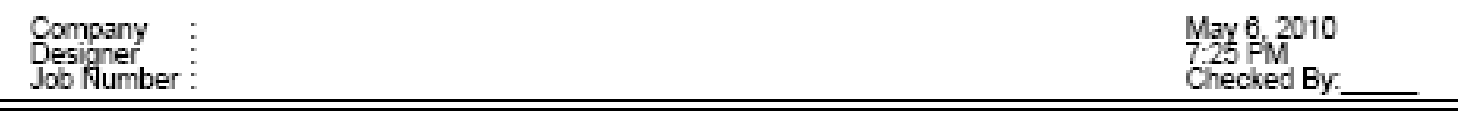

\section{Member Section Forces (Continued)}

\begin{tabular}{|c|c|c|c|c|c|c|}
\hline & LC. & Member labe: & 2ecc & Axisalk1 & ahear"k? & Momentin-fte \\
\hline 19 & & & 4 & 0 & 308 & 1.232 \\
\hline 21 & 1 & $M 5$ & 1 & .192 & -1.491 & -11.933 \\
\hline 22 & & & 2 & 192 & -1.491 & -11.373 \\
\hline 23 & & & 3 & 192 & -1.491 & -10.814 \\
\hline 26 & 1 & $M 6$ & 1 & .192 & -1.491 & -9.696 \\
\hline 27 & & & 2 & 192 & -1.491 & 4.85 \\
\hline 28 & & & 3 & 192 & -1.491 & -0.05 \\
\hline $2 \theta$ & & & 4 & 192 & -1.491 & 4.841 \\
\hline 30 & & & 5 & 192 & -1.491 & 9.687 \\
\hline 31 & 1 & $M 7$ & 1 & 192 & -1.491 & 9.687 \\
\hline 36 & 1 & $1 \mathrm{MB}$ & 1 & 308 & 0 & 0 \\
\hline 37 & & & 2 & 308 & 0 & 0 \\
\hline 38 & & & 3 & 308 & 0 & 0 \\
\hline $3 \theta$ & & & 4 & 308 & 0 & 0 \\
\hline 40 & & & 5 & 308 & 0 & 0 \\
\hline 41 & 1 & 199 & 1 & 308 & 0 & 0 \\
\hline 42 & & & 2 & 308 & 0 & 0 \\
\hline 43 & & & 3 & 308 & 0 & 0 \\
\hline 44 & & & 4 & 308 & 0 & 0 \\
\hline 45 & & & 5 & 308 & 0 & 0 \\
\hline 46 & 1 & M10 & 1 & 308 & 0 & 0 \\
\hline 47 & & & 2 & .308 & 0 & 0 \\
\hline
\end{tabular}

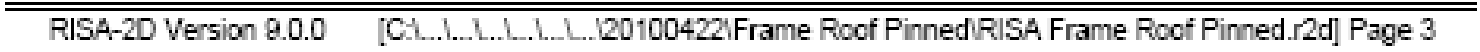




\section{APPENDIX F}

Simplified Design Frame Analysis 
Roof Beam Hinge:

Floor Beam Hinge:

$$
\mathrm{M}_{\mathrm{p}, \mathrm{RBS}}=\quad 3147.3 \mathrm{k} \text {-in }
$$

$\mathrm{M}_{\mathrm{p}, \mathrm{RBS}}=\quad 5020.2 \mathrm{k}-\mathrm{in}$

$\mathrm{V}_{\mathrm{p}, \text { frame }}=\quad 71 \mathrm{k}$

\begin{tabular}{|c|c|c|c|c|c|c|}
\hline $\begin{array}{l}\text { Base } \\
\text { Shear }\end{array}$ & Froof & Ffloor & $\begin{array}{c}\text { Roof Beam } \\
\text { Hinge Moment }\end{array}$ & $\begin{array}{c}\text { Floor Beam } \\
\text { Hinge Moment }\end{array}$ & $\begin{array}{l}\text { Roof Beam } \\
\text { Hinge State }\end{array}$ & $\begin{array}{l}\text { Floor Beam } \\
\text { Hinge State }\end{array}$ \\
\hline $1 \mathrm{k}$ & $0.6 \mathrm{k}$ & $0.4 \mathrm{k}$ & $28.8 \mathrm{k}$-in & $87.6 \mathrm{k}$-in & Elastic & Elastic \\
\hline $2 \mathrm{k}$ & $1.2 \mathrm{k}$ & $0.8 \mathrm{k}$ & $57.6 \mathrm{k}$-in & $175.2 \mathrm{k}$-in & Elastic & Elastic \\
\hline $3 \mathrm{k}$ & $1.8 \mathrm{k}$ & $1.2 \mathrm{k}$ & $86.4 \mathrm{k}$-in & $262.8 \mathrm{k}$-in & Elastic & Elastic \\
\hline $4 \mathrm{k}$ & $2.5 \mathrm{k}$ & $1.5 \mathrm{k}$ & $115.2 \mathrm{k}$-in & 350.4 k-in & Elastic & Elastic \\
\hline $5 \mathrm{k}$ & $3.1 \mathrm{k}$ & $1.9 \mathrm{k}$ & $144.0 \mathrm{k}$-in & $438.0 \mathrm{k}$-in & Elastic & Elastic \\
\hline $6 \mathrm{k}$ & $3.7 \mathrm{k}$ & $2.3 \mathrm{k}$ & $172.8 \mathrm{k}$-in & $525.6 \mathrm{k}$-in & Elastic & Elastic \\
\hline $7 \mathrm{k}$ & $4.3 \mathrm{k}$ & $2.7 \mathrm{k}$ & $201.6 \mathrm{k}$-in & $613.2 \mathrm{k}$-in & Elastic & Elastic \\
\hline $8 \mathrm{k}$ & $4.9 \mathrm{k}$ & $3.1 \mathrm{k}$ & 230.4 k-in & $700.8 \mathrm{k}$-in & Elastic & Elastic \\
\hline $9 \mathrm{k}$ & $5.5 \mathrm{k}$ & $3.5 \mathrm{k}$ & $259.2 \mathrm{k}$-in & $788.4 \mathrm{k}$-in & Elastic & Elastic \\
\hline $10 \mathrm{k}$ & $6.2 \mathrm{k}$ & $3.8 \mathrm{k}$ & $288.0 \mathrm{k}$-in & $876.0 \mathrm{k}$-in & Elastic & Elastic \\
\hline $11 \mathrm{k}$ & $6.8 \mathrm{k}$ & $4.2 \mathrm{k}$ & $316.8 \mathrm{k}$-in & $963.6 \mathrm{k}$-in & Elastic & Elastic \\
\hline $12 \mathrm{k}$ & $7.4 \mathrm{k}$ & $4.6 \mathrm{k}$ & $345.6 \mathrm{k}$-in & $1051.2 \mathrm{k}$-in & Elastic & Elastic \\
\hline $13 \mathrm{k}$ & $8.0 \mathrm{k}$ & $5.0 \mathrm{k}$ & $374.4 \mathrm{k}$-in & $1138.8 \mathrm{k}$-in & Elastic & Elastic \\
\hline $14 \mathrm{k}$ & $8.6 \mathrm{k}$ & $5.4 \mathrm{k}$ & $403.2 \mathrm{k}$-in & $1226.4 \mathrm{k}$-in & Elastic & Elastic \\
\hline $15 \mathrm{k}$ & $9.2 \mathrm{k}$ & $5.8 \mathrm{k}$ & $432.0 \mathrm{k}$-in & $1314.0 \mathrm{k}$-in & Elastic & Elastic \\
\hline $16 \mathrm{k}$ & $9.9 \mathrm{k}$ & $6.1 \mathrm{k}$ & $460.8 \mathrm{k}$-in & $1401.6 \mathrm{k}$-in & Elastic & Elastic \\
\hline $17 \mathrm{k}$ & $10.5 \mathrm{k}$ & $6.5 \mathrm{k}$ & $489.6 \mathrm{k}$-in & $1489.2 \mathrm{k}$-in & Elastic & Elastic \\
\hline $18 \mathrm{k}$ & $11.1 \mathrm{k}$ & $6.9 \mathrm{k}$ & $518.4 \mathrm{k}$-in & $1576.8 \mathrm{k}$-in & Elastic & Elastic \\
\hline $19 \mathrm{k}$ & $11.7 \mathrm{k}$ & $7.3 \mathrm{k}$ & $547.2 \mathrm{k}$-in & 1664.4 k-in & Elastic & Elastic \\
\hline $20 \mathrm{k}$ & $12.3 \mathrm{k}$ & $7.7 \mathrm{k}$ & $576.0 \mathrm{k}$-in & $1752.0 \mathrm{k}$-in & Elastic & Elastic \\
\hline $21 \mathrm{k}$ & $12.9 \mathrm{k}$ & $8.1 \mathrm{k}$ & $604.8 \mathrm{k}$-in & $1839.6 \mathrm{k}$-in & Elastic & Elastic \\
\hline $22 \mathrm{k}$ & $13.6 \mathrm{k}$ & $8.4 \mathrm{k}$ & $633.6 \mathrm{k}$-in & 1927.2 k-in & Elastic & Elastic \\
\hline $23 \mathrm{k}$ & $14.2 \mathrm{k}$ & $8.8 \mathrm{k}$ & $662.4 \mathrm{k}$-in & 2014.8 k-in & Elastic & Elastic \\
\hline $24 \mathrm{k}$ & $14.8 \mathrm{k}$ & $9.2 \mathrm{k}$ & $691.2 \mathrm{k}$-in & $2102.4 \mathrm{k}$-in & Elastic & Elastic \\
\hline $25 \mathrm{k}$ & $15.4 \mathrm{k}$ & $9.6 \mathrm{k}$ & $720.0 \mathrm{k}$-in & $2190.0 \mathrm{k}$-in & Elastic & Elastic \\
\hline $26 \mathrm{k}$ & $16.0 \mathrm{k}$ & $10.0 \mathrm{k}$ & $748.8 \mathrm{k}$-in & $2277.6 \mathrm{k}$-in & Elastic & Elastic \\
\hline $27 \mathrm{k}$ & $16.6 \mathrm{k}$ & $10.4 \mathrm{k}$ & $777.6 \mathrm{k}$-in & $2365.2 \mathrm{k}$-in & Elastic & Elastic \\
\hline $28 \mathrm{k}$ & $17.2 \mathrm{k}$ & $10.8 \mathrm{k}$ & $806.4 \mathrm{k}$-in & $2452.8 \mathrm{k}$-in & Elastic & Elastic \\
\hline $29 \mathrm{k}$ & $17.9 \mathrm{k}$ & $11.1 \mathrm{k}$ & $835.2 \mathrm{k}$-in & $2540.4 \mathrm{k}$-in & Elastic & Elastic \\
\hline $30 \mathrm{k}$ & $18.5 \mathrm{k}$ & $11.5 \mathrm{k}$ & $864.0 \mathrm{k}$-in & $2628.0 \mathrm{k}$-in & Elastic & Elastic \\
\hline $31 \mathrm{k}$ & $19.1 \mathrm{k}$ & $11.9 \mathrm{k}$ & $892.8 \mathrm{k}$-in & $2715.6 \mathrm{k}$-in & Elastic & Elastic \\
\hline $32 \mathrm{k}$ & $19.7 \mathrm{k}$ & $12.3 \mathrm{k}$ & $921.6 \mathrm{k}$-in & $2803.2 \mathrm{k}$-in & Elastic & Elastic \\
\hline $33 \mathrm{k}$ & $20.3 \mathrm{k}$ & $12.7 \mathrm{k}$ & $950.4 \mathrm{k}$-in & $2890.8 \mathrm{k}$-in & Elastic & Elastic \\
\hline $34 \mathrm{k}$ & $20.9 \mathrm{k}$ & $13.1 \mathrm{k}$ & $979.2 \mathrm{k}$-in & 2978.4 k-in & Elastic & Elastic \\
\hline $35 \mathrm{k}$ & $21.6 \mathrm{k}$ & $13.4 \mathrm{k}$ & $1008.0 \mathrm{k}$-in & $3066.0 \mathrm{k}$-in & Elastic & Elastic \\
\hline
\end{tabular}




\begin{tabular}{|c|c|c|c|c|c|c|}
\hline $\begin{array}{l}\text { Base } \\
\text { Shear }\end{array}$ & Froof & Ffloor & $\begin{array}{c}\text { Roof Beam } \\
\text { Hinge Moment }\end{array}$ & $\begin{array}{c}\text { Floor Beam } \\
\text { Hinge Moment }\end{array}$ & $\begin{array}{l}\text { Roof Beam } \\
\text { Hinge State }\end{array}$ & $\begin{array}{l}\text { Floor Beam } \\
\text { Hinge State }\end{array}$ \\
\hline $36 \mathrm{k}$ & $22.2 \mathrm{k}$ & $13.8 \mathrm{k}$ & $1036.8 \mathrm{k}$-in & $3153.6 \mathrm{k}$-in & Elastic & Elastic \\
\hline $37 \mathrm{k}$ & $22.8 \mathrm{k}$ & $14.2 \mathrm{k}$ & $1065.6 \mathrm{k}$-in & $3241.2 \mathrm{k}$-in & Elastic & Elastic \\
\hline $38 \mathrm{k}$ & $23.4 \mathrm{k}$ & $14.6 \mathrm{k}$ & 1094.4 k-in & $3328.8 \mathrm{k}$-in & Elastic & Elastic \\
\hline $39 \mathrm{k}$ & $24.0 \mathrm{k}$ & $15.0 \mathrm{k}$ & $1123.2 \mathrm{k}$-in & $3416.4 \mathrm{k}$-in & Elastic & Elastic \\
\hline $40 \mathrm{k}$ & $24.6 \mathrm{k}$ & $15.4 \mathrm{k}$ & $1152.0 \mathrm{k}$-in & $3504.0 \mathrm{k}$-in & Elastic & Elastic \\
\hline $41 \mathrm{k}$ & $25.3 \mathrm{k}$ & $15.7 \mathrm{k}$ & $1180.8 \mathrm{k}$-in & $3591.6 \mathrm{k}$-in & Elastic & Elastic \\
\hline $42 \mathrm{k}$ & $25.9 \mathrm{k}$ & $16.1 \mathrm{k}$ & $1209.6 \mathrm{k}$-in & $3679.2 \mathrm{k}$-in & Elastic & Elastic \\
\hline $43 \mathrm{k}$ & $26.5 \mathrm{k}$ & $16.5 \mathrm{k}$ & $1238.4 \mathrm{k}$-in & $3766.8 \mathrm{k}$-in & Elastic & Elastic \\
\hline $44 \mathrm{k}$ & $27.1 \mathrm{k}$ & $16.9 \mathrm{k}$ & $1267.2 \mathrm{k}$-in & 3854.4 k-in & Elastic & Elastic \\
\hline $45 \mathrm{k}$ & $27.7 \mathrm{k}$ & $17.3 \mathrm{k}$ & $1296.0 \mathrm{k}$-in & $3942.0 \mathrm{k}$-in & Elastic & Elastic \\
\hline $46 \mathrm{k}$ & $28.3 \mathrm{k}$ & $17.7 \mathrm{k}$ & $1324.8 \mathrm{k}$-in & 4029.6 k-in & Elastic & Elastic \\
\hline $47 \mathrm{k}$ & $29.0 \mathrm{k}$ & $18.0 \mathrm{k}$ & $1353.6 \mathrm{k}$-in & $4117.2 \mathrm{k}$-in & Elastic & Elastic \\
\hline $48 \mathrm{k}$ & $29.6 \mathrm{k}$ & $18.4 \mathrm{k}$ & $1382.4 \mathrm{k}$-in & $4204.8 \mathrm{k}$-in & Elastic & Elastic \\
\hline $49 \mathrm{k}$ & $30.2 \mathrm{k}$ & $18.8 \mathrm{k}$ & $1411.2 \mathrm{k}$-in & 4292.4 k-in & Elastic & Elastic \\
\hline $50 \mathrm{k}$ & $30.8 \mathrm{k}$ & $19.2 \mathrm{k}$ & $1440.0 \mathrm{k}$-in & $4380.0 \mathrm{k}$-in & Elastic & Elastic \\
\hline $51 \mathrm{k}$ & $31.4 \mathrm{k}$ & $19.6 \mathrm{k}$ & $1468.8 \mathrm{k}$-in & $4467.6 \mathrm{k}$-in & Elastic & Elastic \\
\hline $52 \mathrm{k}$ & $32.0 \mathrm{k}$ & $20.0 \mathrm{k}$ & $1497.6 \mathrm{k}$-in & $4555.2 \mathrm{k}$-in & Elastic & Elastic \\
\hline $53 \mathrm{k}$ & $32.6 \mathrm{k}$ & $20.4 \mathrm{k}$ & $1526.4 \mathrm{k}$-in & $4642.8 \mathrm{k}$-in & Elastic & Elastic \\
\hline $54 \mathrm{k}$ & $33.3 \mathrm{k}$ & $20.7 \mathrm{k}$ & $1555.2 \mathrm{k}$-in & 4730.4 k-in & Elastic & Elastic \\
\hline $55 \mathrm{k}$ & $33.9 \mathrm{k}$ & $21.1 \mathrm{k}$ & $1584.0 \mathrm{k}$-in & $4818.0 \mathrm{k}$-in & Elastic & Elastic \\
\hline $56 \mathrm{k}$ & $34.5 \mathrm{k}$ & $21.5 \mathrm{k}$ & $1612.8 \mathrm{k}$-in & $4905.6 \mathrm{k}$-in & Elastic & Elastic \\
\hline $57 \mathrm{k}$ & $35.1 \mathrm{k}$ & $21.9 \mathrm{k}$ & $1641.6 \mathrm{k}$-in & $4993.2 \mathrm{k}$-in & Elastic & Elastic \\
\hline $58 \mathrm{k}$ & $35.7 \mathrm{k}$ & $22.3 \mathrm{k}$ & $1670.4 \mathrm{k}$-in & $5080.8 \mathrm{k}$-in & Elastic & Plastic \\
\hline $59 \mathrm{k}$ & $36.3 \mathrm{k}$ & $22.7 \mathrm{k}$ & $1786.8 \mathrm{k}$-in & $5080.8 \mathrm{k}$-in & Elastic & Plastic \\
\hline $60 \mathrm{k}$ & $37.0 \mathrm{k}$ & $23.0 \mathrm{k}$ & $1903.2 \mathrm{k}$-in & $5080.8 \mathrm{k}$-in & Elastic & Plastic \\
\hline $61 \mathrm{k}$ & $37.6 \mathrm{k}$ & $23.4 \mathrm{k}$ & 2019.6 k-in & $5080.8 \mathrm{k}$-in & Elastic & Plastic \\
\hline $62 \mathrm{k}$ & $38.2 \mathrm{k}$ & $23.8 \mathrm{k}$ & $2136.0 \mathrm{k}$-in & $5080.8 \mathrm{k}$-in & Elastic & Plastic \\
\hline $63 \mathrm{k}$ & $38.8 \mathrm{k}$ & $24.2 \mathrm{k}$ & 2252.4 k-in & $5080.8 \mathrm{k}$-in & Elastic & Plastic \\
\hline $64 \mathrm{k}$ & $39.4 \mathrm{k}$ & $24.6 \mathrm{k}$ & $2368.8 \mathrm{k}$-in & $5080.8 \mathrm{k}$-in & Elastic & Plastic \\
\hline $65 \mathrm{k}$ & $40.0 \mathrm{k}$ & $25.0 \mathrm{k}$ & $2485.2 \mathrm{k}$-in & $5080.8 \mathrm{k}$-in & Elastic & Plastic \\
\hline $66 \mathrm{k}$ & $40.7 \mathrm{k}$ & $25.3 \mathrm{k}$ & 2601.6 k-in & $5080.8 \mathrm{k}$-in & Elastic & Plastic \\
\hline $67 \mathrm{k}$ & $41.3 \mathrm{k}$ & $25.7 \mathrm{k}$ & $2718.0 \mathrm{k}$-in & $5080.8 \mathrm{k}$-in & Elastic & Plastic \\
\hline $68 \mathrm{k}$ & $41.9 \mathrm{k}$ & $26.1 \mathrm{k}$ & $2834.4 \mathrm{k}$-in & $5080.8 \mathrm{k}$-in & Elastic & Plastic \\
\hline $69 \mathrm{k}$ & $42.5 \mathrm{k}$ & $26.5 \mathrm{k}$ & $2950.8 \mathrm{k}$-in & $5080.8 \mathrm{k}$-in & Elastic & Plastic \\
\hline $70 \mathrm{k}$ & $43.1 \mathrm{k}$ & $26.9 \mathrm{k}$ & $3067.2 \mathrm{k}$-in & $5080.8 \mathrm{k}$-in & Elastic & Plastic \\
\hline $71 \mathrm{k}$ & $43.7 \mathrm{k}$ & $27.3 \mathrm{k}$ & $3183.6 \mathrm{k}$-in & $5080.8 \mathrm{k}$-in & Plastic & Plastic \\
\hline
\end{tabular}




\section{APPENDIX G}

Simplified Pushover Frame Analysis 
Roof Beam

Hinge:

Floor Beam

$$
\mathrm{M}_{\mathrm{pr}, \mathrm{RBS}}=\quad 4423.7 \mathrm{k} \text {-in }
$$

Hinge:

$$
\mathrm{M}_{\mathrm{pr} \text { RBS }}=\quad 7056.2 \mathrm{k} \text {-in }
$$

\begin{tabular}{|c|c|c|c|c|c|c|c|}
\hline $\begin{array}{l}\text { Base } \\
\text { Shear }\end{array}$ & Froof & Ffloor & $\begin{array}{l}\text { Roof Beam } \\
\text { Hinge } \\
\text { Moment }\end{array}$ & $\begin{array}{c}\text { Floor Beam } \\
\text { Hinge } \\
\text { Moment }\end{array}$ & $\begin{array}{c}\text { Roof } \\
\text { Beam } \\
\text { Hinge } \\
\text { State }\end{array}$ & $\begin{array}{c}\text { Floor } \\
\text { Beam } \\
\text { Hinge } \\
\text { State }\end{array}$ & $\begin{array}{c}\text { Roof } \\
\text { Deflection }\end{array}$ \\
\hline $1 \mathrm{k}$ & $0.6 \mathrm{k}$ & $0.4 \mathrm{k}$ & $24.2 \mathrm{k}$-in & $49.1 \mathrm{k}$-in & Elastic & Elastic & 0.03 in \\
\hline $2 \mathrm{k}$ & $1.2 \mathrm{k}$ & $0.8 \mathrm{k}$ & $48.4 \mathrm{k}$-in & $98.2 \mathrm{k}$-in & Elastic & Elastic & 0.07 in \\
\hline $3 \mathrm{k}$ & $1.8 \mathrm{k}$ & $1.2 \mathrm{k}$ & $72.7 \mathrm{k}$-in & $147.3 \mathrm{k}$-in & Elastic & Elastic & 0.10 in \\
\hline $4 \mathrm{k}$ & $2.5 \mathrm{k}$ & $1.5 \mathrm{k}$ & $96.9 \mathrm{k}$-in & $196.4 \mathrm{k}$-in & Elastic & Elastic & 0.14 in \\
\hline $5 \mathrm{k}$ & $3.1 \mathrm{k}$ & $1.9 \mathrm{k}$ & $121.1 \mathrm{k}$-in & $245.5 \mathrm{k}$-in & Elastic & Elastic & 0.17 in \\
\hline $6 \mathrm{k}$ & $3.7 \mathrm{k}$ & $2.3 \mathrm{k}$ & $145.3 \mathrm{k}$-in & 294.6 k-in & Elastic & Elastic & 0.20 in \\
\hline $7 \mathrm{k}$ & $4.3 \mathrm{k}$ & $2.7 \mathrm{k}$ & $169.6 \mathrm{k}$-in & $343.7 \mathrm{k}$-in & Elastic & Elastic & 0.24 in \\
\hline $8 \mathrm{k}$ & $4.9 \mathrm{k}$ & $3.1 \mathrm{k}$ & $193.8 \mathrm{k}$-in & $392.8 \mathrm{k}$-in & Elastic & Elastic & 0.27 in \\
\hline $9 \mathrm{k}$ & $5.5 \mathrm{k}$ & $3.5 \mathrm{k}$ & $218.0 \mathrm{k}$-in & $442.0 \mathrm{k}$-in & Elastic & Elastic & 0.31 in \\
\hline $10 \mathrm{k}$ & $6.2 \mathrm{k}$ & $3.8 \mathrm{k}$ & $242.2 \mathrm{k}$-in & $491.1 \mathrm{k}$-in & Elastic & Elastic & 0.34 in \\
\hline $11 \mathrm{k}$ & $6.8 \mathrm{k}$ & $4.2 \mathrm{k}$ & $266.5 \mathrm{k}$-in & $540.2 \mathrm{k}$-in & Elastic & Elastic & 0.37 in \\
\hline $12 \mathrm{k}$ & $7.4 \mathrm{k}$ & $4.6 \mathrm{k}$ & 290.7 k-in & $589.3 \mathrm{k}$-in & Elastic & Elastic & $0.41 \mathrm{in}$ \\
\hline $13 \mathrm{k}$ & $8.0 \mathrm{k}$ & $5.0 \mathrm{k}$ & $314.9 \mathrm{k}$-in & $638.4 \mathrm{k}$-in & Elastic & Elastic & 0.44 in \\
\hline $14 \mathrm{k}$ & $8.6 \mathrm{k}$ & $5.4 \mathrm{k}$ & $339.1 \mathrm{k}$-in & $687.5 \mathrm{k}$-in & Elastic & Elastic & 0.48 in \\
\hline $15 \mathrm{k}$ & $9.2 \mathrm{k}$ & $5.8 \mathrm{k}$ & $363.4 \mathrm{k}$-in & $736.6 \mathrm{k}$-in & Elastic & Elastic & $0.51 \mathrm{in}$ \\
\hline $16 \mathrm{k}$ & $9.9 \mathrm{k}$ & $6.1 \mathrm{k}$ & $387.6 \mathrm{k}$-in & $785.7 \mathrm{k}$-in & Elastic & Elastic & 0.54 in \\
\hline $17 \mathrm{k}$ & $10.5 \mathrm{k}$ & $6.5 \mathrm{k}$ & $411.8 \mathrm{k}$-in & $834.8 \mathrm{k}$-in & Elastic & Elastic & 0.58 in \\
\hline $18 \mathrm{k}$ & $11.1 \mathrm{k}$ & $6.9 \mathrm{k}$ & $436.0 \mathrm{k}$-in & $883.9 \mathrm{k}$-in & Elastic & Elastic & 0.61 in \\
\hline $19 \mathrm{k}$ & $11.7 \mathrm{k}$ & $7.3 \mathrm{k}$ & $460.3 \mathrm{k}$-in & $933.0 \mathrm{k}$-in & Elastic & Elastic & 0.65 in \\
\hline $20 \mathrm{k}$ & $12.3 \mathrm{k}$ & $7.7 \mathrm{k}$ & $484.5 \mathrm{k}$-in & $982.1 \mathrm{k}$-in & Elastic & Elastic & 0.68 in \\
\hline $21 \mathrm{k}$ & $12.9 \mathrm{k}$ & $8.1 \mathrm{k}$ & $508.7 \mathrm{k}$-in & $1031.2 \mathrm{k}$-in & Elastic & Elastic & $0.71 \mathrm{in}$ \\
\hline $22 \mathrm{k}$ & $13.6 \mathrm{k}$ & $8.4 \mathrm{k}$ & $532.9 \mathrm{k}$-in & $1080.3 \mathrm{k}$-in & Elastic & Elastic & 0.75 in \\
\hline $23 \mathrm{k}$ & $14.2 \mathrm{k}$ & $8.8 \mathrm{k}$ & $557.2 \mathrm{k}$-in & 1129.4 k-in & Elastic & Elastic & 0.78 in \\
\hline $24 \mathrm{k}$ & $14.8 \mathrm{k}$ & $9.2 \mathrm{k}$ & $581.4 \mathrm{k}$-in & $1178.5 \mathrm{k}$-in & Elastic & Elastic & 0.82 in \\
\hline $25 \mathrm{k}$ & $15.4 \mathrm{k}$ & $9.6 \mathrm{k}$ & $605.6 \mathrm{k}$-in & $1227.7 \mathrm{k}$-in & Elastic & Elastic & 0.85 in \\
\hline $26 \mathrm{k}$ & $16.0 \mathrm{k}$ & $10.0 \mathrm{k}$ & $629.8 \mathrm{k}$-in & $1276.8 \mathrm{k}$-in & Elastic & Elastic & $0.88 \mathrm{in}$ \\
\hline $27 \mathrm{k}$ & $16.6 \mathrm{k}$ & $10.4 \mathrm{k}$ & $654.0 \mathrm{k}$-in & $1325.9 \mathrm{k}$-in & Elastic & Elastic & 0.92 in \\
\hline $28 \mathrm{k}$ & $17.2 \mathrm{k}$ & $10.8 \mathrm{k}$ & $678.3 \mathrm{k}$-in & $1375.0 \mathrm{k}$-in & Elastic & Elastic & 0.95 in \\
\hline $29 \mathrm{k}$ & $17.9 \mathrm{k}$ & $11.1 \mathrm{k}$ & $702.5 \mathrm{k}$-in & $1424.1 \mathrm{k}$-in & Elastic & Elastic & 0.99 in \\
\hline $30 \mathrm{k}$ & $18.5 \mathrm{k}$ & $11.5 \mathrm{k}$ & $726.7 \mathrm{k}$-in & $1473.2 \mathrm{k}$-in & Elastic & Elastic & $1.02 \mathrm{in}$ \\
\hline $31 \mathrm{k}$ & $19.1 \mathrm{k}$ & $11.9 \mathrm{k}$ & $750.9 \mathrm{k}$-in & $1522.3 \mathrm{k}$-in & Elastic & Elastic & $1.05 \mathrm{in}$ \\
\hline $32 \mathrm{k}$ & $19.7 \mathrm{k}$ & $12.3 \mathrm{k}$ & $775.2 \mathrm{k}$-in & $1571.4 \mathrm{k}$-in & Elastic & Elastic & $1.09 \mathrm{in}$ \\
\hline $33 \mathrm{k}$ & $20.3 \mathrm{k}$ & $12.7 \mathrm{k}$ & 799.4 k-in & $1620.5 \mathrm{k}$-in & Elastic & Elastic & $1.12 \mathrm{in}$ \\
\hline $34 \mathrm{k}$ & $20.9 \mathrm{k}$ & $13.1 \mathrm{k}$ & $823.6 \mathrm{k}$-in & $1669.6 \mathrm{k}$-in & Elastic & Elastic & 1.16 in \\
\hline
\end{tabular}

$$
\mathrm{V}_{\mathrm{pr} \text {,frame }}=166 \mathrm{k}
$$




\begin{tabular}{|c|c|c|c|c|c|c|c|}
\hline $\begin{array}{l}\text { Base } \\
\text { Shear }\end{array}$ & Froof & Ffloor & $\begin{array}{l}\text { Roof Beam } \\
\text { Hinge } \\
\text { Moment }\end{array}$ & $\begin{array}{l}\text { Floor Beam } \\
\text { Hinge } \\
\text { Moment }\end{array}$ & $\begin{array}{c}\text { Roof } \\
\text { Beam } \\
\text { Hinge } \\
\text { State } \\
\end{array}$ & $\begin{array}{c}\text { Floor } \\
\text { Beam } \\
\text { Hinge } \\
\text { State }\end{array}$ & $\begin{array}{c}\text { Roof } \\
\text { Deflection }\end{array}$ \\
\hline $35 \mathrm{k}$ & $21.6 \mathrm{k}$ & $13.4 \mathrm{k}$ & $847.8 \mathrm{k}$-in & 1718.7 k-in & Elastic & Elastic & $1.19 \mathrm{in}$ \\
\hline $36 \mathrm{k}$ & $22.2 \mathrm{k}$ & $13.8 \mathrm{k}$ & $872.1 \mathrm{k}$-in & $1767.8 \mathrm{k}$-in & Elastic & Elastic & $1.22 \mathrm{in}$ \\
\hline $37 \mathrm{k}$ & $22.8 \mathrm{k}$ & $14.2 \mathrm{k}$ & $896.3 \mathrm{k}$-in & 1816.9 k-in & Elastic & Elastic & 1.26 in \\
\hline $38 \mathrm{k}$ & $23.4 \mathrm{k}$ & $14.6 \mathrm{k}$ & $920.5 \mathrm{k}$-in & $1866.0 \mathrm{k}$-in & Elastic & Elastic & $1.29 \mathrm{in}$ \\
\hline $39 \mathrm{k}$ & $24.0 \mathrm{k}$ & $15.0 \mathrm{k}$ & $944.7 \mathrm{k}$-in & 1915.1 k-in & Elastic & Elastic & $1.33 \mathrm{in}$ \\
\hline $40 \mathrm{k}$ & $24.6 \mathrm{k}$ & $15.4 \mathrm{k}$ & $969.0 \mathrm{k}$-in & 1964.2 k-in & Elastic & Elastic & 1.36 in \\
\hline $41 \mathrm{k}$ & $25.3 \mathrm{k}$ & $15.7 \mathrm{k}$ & $993.2 \mathrm{k}$-in & 2013.3 k-in & Elastic & Elastic & $1.39 \mathrm{in}$ \\
\hline $42 \mathrm{k}$ & $25.9 \mathrm{k}$ & $16.1 \mathrm{k}$ & 1017.4 k-in & 2062.5 k-in & Elastic & Elastic & $1.43 \mathrm{in}$ \\
\hline $43 \mathrm{k}$ & $26.5 \mathrm{k}$ & $16.5 \mathrm{k}$ & 1041.6 k-in & 2111.6 k-in & Elastic & Elastic & $1.46 \mathrm{in}$ \\
\hline $44 \mathrm{k}$ & $27.1 \mathrm{k}$ & $16.9 \mathrm{k}$ & 1065.9 k-in & 2160.7 k-in & Elastic & Elastic & $1.50 \mathrm{in}$ \\
\hline $45 \mathrm{k}$ & $27.7 \mathrm{k}$ & $17.3 \mathrm{k}$ & 1090.1 k-in & 2209.8 k-in & Elastic & Elastic & $1.53 \mathrm{in}$ \\
\hline $46 \mathrm{k}$ & $28.3 \mathrm{k}$ & $17.7 \mathrm{k}$ & 1114.3 k-in & 2258.9 k-in & Elastic & Elastic & $1.56 \mathrm{in}$ \\
\hline $47 \mathrm{k}$ & $29.0 \mathrm{k}$ & $18.0 \mathrm{k}$ & 1138.5 k-in & $2308.0 \mathrm{k}$-in & Elastic & Elastic & $1.60 \mathrm{in}$ \\
\hline $48 \mathrm{k}$ & $29.6 \mathrm{k}$ & $18.4 \mathrm{k}$ & 1162.8 k-in & $2357.1 \mathrm{k}$-in & Elastic & Elastic & $1.63 \mathrm{in}$ \\
\hline $49 \mathrm{k}$ & $30.2 \mathrm{k}$ & $18.8 \mathrm{k}$ & 1187.0 k-in & 2406.2 k-in & Elastic & Elastic & $1.67 \mathrm{in}$ \\
\hline $50 \mathrm{k}$ & $30.8 \mathrm{k}$ & $19.2 \mathrm{k}$ & 1211.2 k-in & $2455.3 \mathrm{k}$-in & Elastic & Elastic & $1.70 \mathrm{in}$ \\
\hline $51 \mathrm{k}$ & $31.4 \mathrm{k}$ & $19.6 \mathrm{k}$ & 1235.4 k-in & 2504.4 k-in & Elastic & Elastic & $1.73 \mathrm{in}$ \\
\hline $52 \mathrm{k}$ & $32.0 \mathrm{k}$ & $20.0 \mathrm{k}$ & 1259.6 k-in & 2553.5 k-in & Elastic & Elastic & $1.77 \mathrm{in}$ \\
\hline $53 \mathrm{k}$ & $32.6 \mathrm{k}$ & $20.4 \mathrm{k}$ & 1283.9 k-in & 2602.6 k-in & Elastic & Elastic & $1.80 \mathrm{in}$ \\
\hline $54 \mathrm{k}$ & $33.3 \mathrm{k}$ & $20.7 \mathrm{k}$ & 1308.1 k-in & 2651.7 k-in & Elastic & Elastic & $1.84 \mathrm{in}$ \\
\hline $55 \mathrm{k}$ & $33.9 \mathrm{k}$ & $21.1 \mathrm{k}$ & 1332.3 k-in & 2700.8 k-in & Elastic & Elastic & $1.87 \mathrm{in}$ \\
\hline $56 \mathrm{k}$ & $34.5 \mathrm{k}$ & $21.5 \mathrm{k}$ & 1356.5 k-in & 2749.9 k-in & Elastic & Elastic & $1.90 \mathrm{in}$ \\
\hline $57 \mathrm{k}$ & $35.1 \mathrm{k}$ & $21.9 \mathrm{k}$ & 1380.8 k-in & 2799.0 k-in & Elastic & Elastic & $1.94 \mathrm{in}$ \\
\hline $58 \mathrm{k}$ & $35.7 \mathrm{k}$ & $22.3 \mathrm{k}$ & 1405.0 k-in & 2848.1 k-in & Elastic & Elastic & $1.97 \mathrm{in}$ \\
\hline $59 \mathrm{k}$ & $36.3 \mathrm{k}$ & $22.7 \mathrm{k}$ & 1429.2 k-in & $2897.3 \mathrm{k}$-in & Elastic & Elastic & $2.01 \mathrm{in}$ \\
\hline $60 \mathrm{k}$ & $37.0 \mathrm{k}$ & $23.0 \mathrm{k}$ & 1453.4 k-in & 2946.4 k-in & Elastic & Elastic & $2.04 \mathrm{in}$ \\
\hline $61 \mathrm{k}$ & $37.6 \mathrm{k}$ & $23.4 \mathrm{k}$ & 1477.7 k-in & 2995.5 k-in & Elastic & Elastic & 2.07 in \\
\hline $62 \mathrm{k}$ & $38.2 \mathrm{k}$ & $23.8 \mathrm{k}$ & 1501.9 k-in & 3044.6 k-in & Elastic & Elastic & $2.11 \mathrm{in}$ \\
\hline $63 \mathrm{k}$ & $38.8 \mathrm{k}$ & $24.2 \mathrm{k}$ & $1526.1 \mathrm{k}$-in & 3093.7 k-in & Elastic & Elastic & $2.14 \mathrm{in}$ \\
\hline $64 \mathrm{k}$ & $39.4 \mathrm{k}$ & $24.6 \mathrm{k}$ & 1550.3 k-in & $3142.8 \mathrm{k}$-in & Elastic & Elastic & $2.18 \mathrm{in}$ \\
\hline $65 \mathrm{k}$ & $40.0 \mathrm{k}$ & $25.0 \mathrm{k}$ & 1574.6 k-in & 3191.9 k-in & Elastic & Elastic & $2.21 \mathrm{in}$ \\
\hline $66 \mathrm{k}$ & $40.7 \mathrm{k}$ & $25.3 \mathrm{k}$ & 1598.8 k-in & $3241.0 \mathrm{k}$-in & Elastic & Elastic & $2.24 \mathrm{in}$ \\
\hline $67 \mathrm{k}$ & $41.3 \mathrm{k}$ & $25.7 \mathrm{k}$ & 1623.0 k-in & $3290.1 \mathrm{k}$-in & Elastic & Elastic & 2.28 in \\
\hline $68 \mathrm{k}$ & $41.9 \mathrm{k}$ & $26.1 \mathrm{k}$ & 1647.2 k-in & $3339.2 \mathrm{k}$-in & Elastic & Elastic & $2.31 \mathrm{in}$ \\
\hline $69 \mathrm{k}$ & $42.5 \mathrm{k}$ & $26.5 \mathrm{k}$ & 1671.5 k-in & 3388.3 k-in & Elastic & Elastic & 2.35 in \\
\hline $70 \mathrm{k}$ & $43.1 \mathrm{k}$ & $26.9 \mathrm{k}$ & 1695.7 k-in & 3437.4 k-in & Elastic & Elastic & 2.38 in \\
\hline $71 \mathrm{k}$ & $43.7 \mathrm{k}$ & $27.3 \mathrm{k}$ & 1719.9 k-in & 3486.5 k-in & Elastic & Elastic & $2.41 \mathrm{in}$ \\
\hline $72 \mathrm{k}$ & $44.4 \mathrm{k}$ & $27.6 \mathrm{k}$ & 1744.1 k-in & 3535.6 k-in & Elastic & Elastic & $2.45 \mathrm{in}$ \\
\hline $73 \mathrm{k}$ & $45.0 \mathrm{k}$ & $28.0 \mathrm{k}$ & 1768.4 k-in & $3584.7 \mathrm{k}$-in & Elastic & Elastic & 2.48 in \\
\hline $74 \mathrm{k}$ & $45.6 \mathrm{k}$ & $28.4 \mathrm{k}$ & 1792.6 k-in & 3633.8 k-in & Elastic & Elastic & 2.52 in \\
\hline $75 \mathrm{k}$ & $46.2 \mathrm{k}$ & $28.8 \mathrm{k}$ & 1816.8 k-in & $3683.0 \mathrm{k}$-in & Elastic & Elastic & $2.55 \mathrm{in}$ \\
\hline $76 \mathrm{k}$ & $46.8 \mathrm{k}$ & $29.2 \mathrm{k}$ & 1841.0 k-in & $3732.1 \mathrm{k}$-in & Elastic & Elastic & 2.58 in \\
\hline $77 \mathrm{k}$ & $47.4 \mathrm{k}$ & $29.6 \mathrm{k}$ & 1865.2 k-in & $3781.2 \mathrm{k}$-in & Elastic & Elastic & $2.62 \mathrm{in}$ \\
\hline $78 \mathrm{k}$ & $48.0 \mathrm{k}$ & $30.0 \mathrm{k}$ & 1889.5 k-in & 3830.3 k-in & Elastic & Elastic & 2.65 in \\
\hline
\end{tabular}




\begin{tabular}{|c|c|c|c|c|c|c|c|}
\hline $\begin{array}{l}\text { Base } \\
\text { Shear }\end{array}$ & Froof & Ffloor & $\begin{array}{l}\text { Roof Beam } \\
\text { Hinge } \\
\text { Moment }\end{array}$ & $\begin{array}{l}\text { Floor Beam } \\
\text { Hinge } \\
\text { Moment }\end{array}$ & $\begin{array}{c}\text { Roof } \\
\text { Beam } \\
\text { Hinge } \\
\text { State } \\
\end{array}$ & $\begin{array}{c}\text { Floor } \\
\text { Beam } \\
\text { Hinge } \\
\text { State }\end{array}$ & $\begin{array}{c}\text { Roof } \\
\text { Deflection }\end{array}$ \\
\hline $79 \mathrm{k}$ & $48.7 \mathrm{k}$ & $30.3 \mathrm{k}$ & 1913.7 k-in & 3879.4 k-in & Elastic & Elastic & $2.69 \mathrm{in}$ \\
\hline $80 \mathrm{k}$ & $49.3 \mathrm{k}$ & $30.7 \mathrm{k}$ & 1937.9 k-in & 3928.5 k-in & Elastic & Elastic & $2.72 \mathrm{in}$ \\
\hline $81 \mathrm{k}$ & $49.9 \mathrm{k}$ & $31.1 \mathrm{k}$ & 1962.1 k-in & 3977.6 k-in & Elastic & Elastic & 2.75 in \\
\hline $82 \mathrm{k}$ & $50.5 \mathrm{k}$ & $31.5 \mathrm{k}$ & 1986.4 k-in & 4026.7 k-in & Elastic & Elastic & $2.79 \mathrm{in}$ \\
\hline $83 \mathrm{k}$ & $51.1 \mathrm{k}$ & $31.9 \mathrm{k}$ & 2010.6 k-in & $4075.8 \mathrm{k}$-in & Elastic & Elastic & 2.82 in \\
\hline $84 \mathrm{k}$ & $51.7 \mathrm{k}$ & $32.3 \mathrm{k}$ & 2034.8 k-in & 4124.9 k-in & Elastic & Elastic & 2.86 in \\
\hline $85 \mathrm{k}$ & $52.4 \mathrm{k}$ & $32.6 \mathrm{k}$ & 2059.0 k-in & $4174.0 \mathrm{k}$-in & Elastic & Elastic & 2.89 in \\
\hline $86 \mathrm{k}$ & $53.0 \mathrm{k}$ & $33.0 \mathrm{k}$ & 2083.3 k-in & $4223.1 \mathrm{k}$-in & Elastic & Elastic & $2.92 \mathrm{in}$ \\
\hline $87 \mathrm{k}$ & $53.6 \mathrm{k}$ & $33.4 \mathrm{k}$ & 2107.5 k-in & $4272.2 \mathrm{k}$-in & Elastic & Elastic & $2.96 \mathrm{in}$ \\
\hline $88 \mathrm{k}$ & $54.2 \mathrm{k}$ & $33.8 \mathrm{k}$ & 2131.7 k-in & 4321.3 k-in & Elastic & Elastic & 2.99 in \\
\hline $89 \mathrm{k}$ & $54.8 \mathrm{k}$ & $34.2 \mathrm{k}$ & 2155.9 k-in & 4370.4 k-in & Elastic & Elastic & 3.03 in \\
\hline $90 \mathrm{k}$ & $55.4 \mathrm{k}$ & $34.6 \mathrm{k}$ & 2180.2 k-in & 4419.5 k-in & Elastic & Elastic & 3.06 in \\
\hline $91 \mathrm{k}$ & $56.1 \mathrm{k}$ & $34.9 \mathrm{k}$ & 2204.4 k-in & 4468.6 k-in & Elastic & Elastic & 3.09 in \\
\hline $92 \mathrm{k}$ & $56.7 \mathrm{k}$ & $35.3 \mathrm{k}$ & 2228.6 k-in & 4517.8 k-in & Elastic & Elastic & 3.13 in \\
\hline $93 \mathrm{k}$ & $57.3 \mathrm{k}$ & $35.7 \mathrm{k}$ & 2252.8 k-in & 4566.9 k-in & Elastic & Elastic & 3.16 in \\
\hline $94 \mathrm{k}$ & $57.9 \mathrm{k}$ & $36.1 \mathrm{k}$ & 2277.1 k-in & $4616.0 \mathrm{k}$-in & Elastic & Elastic & 3.20 in \\
\hline $95 \mathrm{k}$ & $58.5 \mathrm{k}$ & $36.5 \mathrm{k}$ & 2301.3 k-in & $4665.1 \mathrm{k}$-in & Elastic & Elastic & 3.23 in \\
\hline $96 \mathrm{k}$ & $59.1 \mathrm{k}$ & $36.9 \mathrm{k}$ & 2325.5 k-in & 4714.2 k-in & Elastic & Elastic & 3.26 in \\
\hline $97 \mathrm{k}$ & $59.8 \mathrm{k}$ & $37.2 \mathrm{k}$ & 2349.7 k-in & $4763.3 \mathrm{k}$-in & Elastic & Elastic & 3.30 in \\
\hline $98 \mathrm{k}$ & $60.4 \mathrm{k}$ & $37.6 \mathrm{k}$ & 2374.0 k-in & 4812.4 k-in & Elastic & Elastic & 3.33 in \\
\hline $99 \mathrm{k}$ & $61.0 \mathrm{k}$ & $38.0 \mathrm{k}$ & 2398.2 k-in & $4861.5 \mathrm{k}$-in & Elastic & Elastic & 3.37 in \\
\hline $100 \mathrm{k}$ & $61.6 \mathrm{k}$ & $38.4 \mathrm{k}$ & 2422.4 k-in & 4910.6 k-in & Elastic & Elastic & $3.40 \mathrm{in}$ \\
\hline $101 \mathrm{k}$ & $62.2 \mathrm{k}$ & $38.8 \mathrm{k}$ & 2446.6 k-in & 4959.7 k-in & Elastic & Elastic & 3.43 in \\
\hline $102 \mathrm{k}$ & $62.8 \mathrm{k}$ & $39.2 \mathrm{k}$ & 2470.8 k-in & 5008.8 k-in & Elastic & Elastic & 3.47 in \\
\hline $103 \mathrm{k}$ & $63.4 \mathrm{k}$ & $39.6 \mathrm{k}$ & $2495.1 \mathrm{k}$-in & $5057.9 \mathrm{k}$-in & Elastic & Elastic & 3.50 in \\
\hline $104 \mathrm{k}$ & $64.1 \mathrm{k}$ & $39.9 \mathrm{k}$ & 2519.3 k-in & $5107.0 \mathrm{k}$-in & Elastic & Elastic & $3.54 \mathrm{in}$ \\
\hline $105 \mathrm{k}$ & $64.7 \mathrm{k}$ & $40.3 \mathrm{k}$ & 2543.5 k-in & $5156.1 \mathrm{k}$-in & Elastic & Elastic & 3.57 in \\
\hline $106 \mathrm{k}$ & $65.3 \mathrm{k}$ & $40.7 \mathrm{k}$ & 2567.7 k-in & $5205.2 \mathrm{k}$-in & Elastic & Elastic & $3.60 \mathrm{in}$ \\
\hline $107 \mathrm{k}$ & $65.9 \mathrm{k}$ & $41.1 \mathrm{k}$ & 2592.0 k-in & $5254.3 \mathrm{k}$-in & Elastic & Elastic & $3.64 \mathrm{in}$ \\
\hline $108 \mathrm{k}$ & $66.5 \mathrm{k}$ & $41.5 \mathrm{k}$ & 2616.2 k-in & 5303.4 k-in & Elastic & Elastic & $3.67 \mathrm{in}$ \\
\hline $109 \mathrm{k}$ & $67.1 \mathrm{k}$ & $41.9 \mathrm{k}$ & 2640.4 k-in & $5352.6 \mathrm{k}$-in & Elastic & Elastic & $3.71 \mathrm{in}$ \\
\hline $110 \mathrm{k}$ & $67.8 \mathrm{k}$ & $42.2 \mathrm{k}$ & 2664.6 k-in & 5401.7 k-in & Elastic & Elastic & 3.74 in \\
\hline $111 \mathrm{k}$ & $68.4 \mathrm{k}$ & $42.6 \mathrm{k}$ & 2688.9 k-in & $5450.8 \mathrm{k}$-in & Elastic & Elastic & 3.77 in \\
\hline $112 \mathrm{k}$ & $69.0 \mathrm{k}$ & $43.0 \mathrm{k}$ & 2713.1 k-in & 5499.9 k-in & Elastic & Elastic & $3.81 \mathrm{in}$ \\
\hline $113 \mathrm{k}$ & $69.6 \mathrm{k}$ & $43.4 \mathrm{k}$ & 2737.3 k-in & $5549.0 \mathrm{k}$-in & Elastic & Elastic & 3.84 in \\
\hline $114 \mathrm{k}$ & $70.2 \mathrm{k}$ & $43.8 \mathrm{k}$ & $2761.5 \mathrm{k}$-in & $5598.1 \mathrm{k}$-in & Elastic & Elastic & 3.88 in \\
\hline $115 \mathrm{k}$ & $70.8 \mathrm{k}$ & $44.2 \mathrm{k}$ & 2785.8 k-in & $5647.2 \mathrm{k}$-in & Elastic & Elastic & $3.91 \mathrm{in}$ \\
\hline $116 \mathrm{k}$ & $71.5 \mathrm{k}$ & $44.5 \mathrm{k}$ & 2810.0 k-in & $5696.3 \mathrm{k}$-in & Elastic & Elastic & 3.94 in \\
\hline $117 \mathrm{k}$ & $72.1 \mathrm{k}$ & $44.9 \mathrm{k}$ & 2834.2 k-in & 5745.4 k-in & Elastic & Elastic & 3.98 in \\
\hline $118 \mathrm{k}$ & $72.7 \mathrm{k}$ & $45.3 \mathrm{k}$ & 2858.4 k-in & 5794.5 k-in & Elastic & Elastic & $4.01 \mathrm{in}$ \\
\hline $119 \mathrm{k}$ & $73.3 \mathrm{k}$ & $45.7 \mathrm{k}$ & 2882.7 k-in & 5843.6 k-in & Elastic & Elastic & $4.05 \mathrm{in}$ \\
\hline $120 \mathrm{k}$ & $73.9 \mathrm{k}$ & $46.1 \mathrm{k}$ & 2906.9 k-in & 5892.7 k-in & Elastic & Elastic & 4.08 in \\
\hline $121 \mathrm{k}$ & $74.5 \mathrm{k}$ & $46.5 \mathrm{k}$ & 2931.1 k-in & 5941.8 k-in & Elastic & Elastic & $4.11 \mathrm{in}$ \\
\hline $122 \mathrm{k}$ & $75.2 \mathrm{k}$ & $46.8 \mathrm{k}$ & 2955.3 k-in & 5990.9 k-in & Elastic & Elastic & 4.15 in \\
\hline
\end{tabular}




\begin{tabular}{|c|c|c|c|c|c|c|c|}
\hline $\begin{array}{l}\text { Base } \\
\text { Shear }\end{array}$ & Froof & Ffloor & $\begin{array}{l}\text { Roof Beam } \\
\text { Hinge } \\
\text { Moment }\end{array}$ & $\begin{array}{c}\text { Floor Beam } \\
\text { Hinge } \\
\text { Moment }\end{array}$ & $\begin{array}{c}\text { Roof } \\
\text { Beam } \\
\text { Hinge } \\
\text { State }\end{array}$ & $\begin{array}{c}\text { Floor } \\
\text { Beam } \\
\text { Hinge } \\
\text { State }\end{array}$ & $\begin{array}{c}\text { Roof } \\
\text { Deflection }\end{array}$ \\
\hline $123 \mathrm{k}$ & $75.8 \mathrm{k}$ & $47.2 \mathrm{k}$ & $2979.6 \mathrm{k}$-in & $6040.0 \mathrm{k}$-in & Elastic & Elastic & 4.18 in \\
\hline $124 \mathrm{k}$ & $76.4 \mathrm{k}$ & $47.6 \mathrm{k}$ & $3003.8 \mathrm{k}$-in & $6089.1 \mathrm{k}$-in & Elastic & Elastic & 4.22 in \\
\hline $125 \mathrm{k}$ & $77.0 \mathrm{k}$ & $48.0 \mathrm{k}$ & $3028.0 \mathrm{k}$-in & $6138.3 \mathrm{k}$-in & Elastic & Elastic & $4.25 \mathrm{in}$ \\
\hline $126 \mathrm{k}$ & $77.6 \mathrm{k}$ & $48.4 \mathrm{k}$ & $3052.2 \mathrm{k}$-in & $6187.4 \mathrm{k}$-in & Elastic & Elastic & $4.28 \mathrm{in}$ \\
\hline $127 \mathrm{k}$ & $78.2 \mathrm{k}$ & $48.8 \mathrm{k}$ & 3076.4 k-in & $6236.5 \mathrm{k}$-in & Elastic & Elastic & $4.32 \mathrm{in}$ \\
\hline $128 \mathrm{k}$ & $78.8 \mathrm{k}$ & $49.2 \mathrm{k}$ & $3100.7 \mathrm{k}$-in & $6285.6 \mathrm{k}$-in & Elastic & Elastic & $4.35 \mathrm{in}$ \\
\hline $129 \mathrm{k}$ & $79.5 \mathrm{k}$ & $49.5 \mathrm{k}$ & $3124.9 \mathrm{k}$-in & $6334.7 \mathrm{k}$-in & Elastic & Elastic & $4.39 \mathrm{in}$ \\
\hline $130 \mathrm{k}$ & $80.1 \mathrm{k}$ & $49.9 \mathrm{k}$ & $3149.1 \mathrm{k}$-in & $6383.8 \mathrm{k}$-in & Elastic & Elastic & $4.42 \mathrm{in}$ \\
\hline $131 \mathrm{k}$ & $80.7 \mathrm{k}$ & $50.3 \mathrm{k}$ & $3173.3 \mathrm{k}$-in & $6432.9 \mathrm{k}$-in & Elastic & Elastic & $4.45 \mathrm{in}$ \\
\hline $132 \mathrm{k}$ & $81.3 \mathrm{k}$ & $50.7 \mathrm{k}$ & $3197.6 \mathrm{k}$-in & $6482.0 \mathrm{k}$-in & Elastic & Elastic & $4.49 \mathrm{in}$ \\
\hline $133 \mathrm{k}$ & $81.9 \mathrm{k}$ & $51.1 \mathrm{k}$ & $3221.8 \mathrm{k}$-in & $6531.1 \mathrm{k}$-in & Elastic & Elastic & $4.52 \mathrm{in}$ \\
\hline $134 \mathrm{k}$ & $82.5 \mathrm{k}$ & $51.5 \mathrm{k}$ & $3246.0 \mathrm{k}$-in & $6580.2 \mathrm{k}$-in & Elastic & Elastic & 4.56 in \\
\hline $135 \mathrm{k}$ & $83.2 \mathrm{k}$ & $51.8 \mathrm{k}$ & $3270.2 \mathrm{k}$-in & $6629.3 \mathrm{k}$-in & Elastic & Elastic & $4.59 \mathrm{in}$ \\
\hline $136 \mathrm{k}$ & $83.8 \mathrm{k}$ & $52.2 \mathrm{k}$ & $3294.5 \mathrm{k}$-in & $6678.4 \mathrm{k}$-in & Elastic & Elastic & $4.62 \mathrm{in}$ \\
\hline $137 \mathrm{k}$ & $84.4 \mathrm{k}$ & $52.6 \mathrm{k}$ & $3318.7 \mathrm{k}$-in & $6727.5 \mathrm{k}$-in & Elastic & Elastic & $4.66 \mathrm{in}$ \\
\hline $138 \mathrm{k}$ & $85.0 \mathrm{k}$ & $53.0 \mathrm{k}$ & $3342.9 \mathrm{k}$-in & $6776.6 \mathrm{k}$-in & Elastic & Elastic & $4.69 \mathrm{in}$ \\
\hline $139 \mathrm{k}$ & $85.6 \mathrm{k}$ & $53.4 \mathrm{k}$ & $3367.1 \mathrm{k}$-in & $6825.7 \mathrm{k}$-in & Elastic & Elastic & $4.73 \mathrm{in}$ \\
\hline $140 \mathrm{k}$ & $86.2 \mathrm{k}$ & $53.8 \mathrm{k}$ & $3391.4 \mathrm{k}$-in & $6874.8 \mathrm{k}$-in & Elastic & Elastic & $4.76 \mathrm{in}$ \\
\hline $141 \mathrm{k}$ & $86.9 \mathrm{k}$ & $54.1 \mathrm{k}$ & $3415.6 \mathrm{k}$-in & 6923.9 k-in & Elastic & Elastic & $4.79 \mathrm{in}$ \\
\hline $142 \mathrm{k}$ & $87.5 \mathrm{k}$ & $54.5 \mathrm{k}$ & $3439.8 \mathrm{k}$-in & $6973.1 \mathrm{k}$-in & Elastic & Elastic & $4.83 \mathrm{in}$ \\
\hline $143 \mathrm{k}$ & $88.1 \mathrm{k}$ & $54.9 \mathrm{k}$ & $3464.0 \mathrm{k}$-in & $7022.2 \mathrm{k}$-in & Elastic & Elastic & $4.86 \mathrm{in}$ \\
\hline $144 \mathrm{k}$ & $88.7 \mathrm{k}$ & $55.3 \mathrm{k}$ & $3488.3 \mathrm{k}$-in & $7071.3 \mathrm{k}$-in & Elastic & Plastic & $4.90 \mathrm{in}$ \\
\hline $145 \mathrm{k}$ & $89.3 \mathrm{k}$ & $55.7 \mathrm{k}$ & $3532.2 \mathrm{k}$-in & $7071.3 \mathrm{k}$-in & Elastic & Plastic & $4.97 \mathrm{in}$ \\
\hline $146 \mathrm{k}$ & $89.9 \mathrm{k}$ & $56.1 \mathrm{k}$ & $3576.2 \mathrm{k}$-in & $7071.3 \mathrm{k}$-in & Elastic & Plastic & $5.05 \mathrm{in}$ \\
\hline $147 \mathrm{k}$ & $90.6 \mathrm{k}$ & $56.4 \mathrm{k}$ & $3620.2 \mathrm{k}$-in & $7071.3 \mathrm{k}$-in & Elastic & Plastic & $5.13 \mathrm{in}$ \\
\hline $148 \mathrm{k}$ & $91.2 \mathrm{k}$ & $56.8 \mathrm{k}$ & $3664.2 \mathrm{k}$-in & $7071.3 \mathrm{k}$-in & Elastic & Plastic & $5.21 \mathrm{in}$ \\
\hline $149 \mathrm{k}$ & $91.8 \mathrm{k}$ & $57.2 \mathrm{k}$ & $3708.2 \mathrm{k}$-in & $7071.3 \mathrm{k}$-in & Elastic & Plastic & $5.29 \mathrm{in}$ \\
\hline $150 \mathrm{k}$ & $92.4 \mathrm{k}$ & $57.6 \mathrm{k}$ & $3752.2 \mathrm{k}$-in & $7071.3 \mathrm{k}$-in & Elastic & Plastic & $5.36 \mathrm{in}$ \\
\hline $151 \mathrm{k}$ & $93.0 \mathrm{k}$ & $58.0 \mathrm{k}$ & $3796.2 \mathrm{k}$-in & $7071.3 \mathrm{k}$-in & Elastic & Plastic & $5.44 \mathrm{in}$ \\
\hline $152 \mathrm{k}$ & $93.6 \mathrm{k}$ & $58.4 \mathrm{k}$ & $3840.1 \mathrm{k}$-in & $7071.3 \mathrm{k}$-in & Elastic & Plastic & $5.52 \mathrm{in}$ \\
\hline $153 \mathrm{k}$ & $94.2 \mathrm{k}$ & $58.8 \mathrm{k}$ & $3884.1 \mathrm{k}$-in & $7071.3 \mathrm{k}$-in & Elastic & Plastic & $5.60 \mathrm{in}$ \\
\hline $154 \mathrm{k}$ & $94.9 \mathrm{k}$ & $59.1 \mathrm{k}$ & $3928.1 \mathrm{k}$-in & $7071.3 \mathrm{k}$-in & Elastic & Plastic & $5.68 \mathrm{in}$ \\
\hline $155 \mathrm{k}$ & $95.5 \mathrm{k}$ & $59.5 \mathrm{k}$ & $3972.1 \mathrm{k}$-in & $7071.3 \mathrm{k}$-in & Elastic & Plastic & $5.75 \mathrm{in}$ \\
\hline $156 \mathrm{k}$ & $96.1 \mathrm{k}$ & $59.9 \mathrm{k}$ & $4016.1 \mathrm{k}$-in & $7071.3 \mathrm{k}$-in & Elastic & Plastic & $5.83 \mathrm{in}$ \\
\hline $157 \mathrm{k}$ & $96.7 \mathrm{k}$ & $60.3 \mathrm{k}$ & $4060.1 \mathrm{k}$-in & $7071.3 \mathrm{k}$-in & Elastic & Plastic & $5.91 \mathrm{in}$ \\
\hline $158 \mathrm{k}$ & $97.3 \mathrm{k}$ & $60.7 \mathrm{k}$ & $4104.1 \mathrm{k}$-in & $7071.3 \mathrm{k}$-in & Elastic & Plastic & $5.99 \mathrm{in}$ \\
\hline $159 \mathrm{k}$ & $97.9 \mathrm{k}$ & $61.1 \mathrm{k}$ & $4148.0 \mathrm{k}$-in & $7071.3 \mathrm{k}$-in & Elastic & Plastic & $6.07 \mathrm{in}$ \\
\hline $160 \mathrm{k}$ & $98.6 \mathrm{k}$ & $61.4 \mathrm{k}$ & $4192.0 \mathrm{k}$-in & $7071.3 \mathrm{k}$-in & Elastic & Plastic & $6.14 \mathrm{in}$ \\
\hline $161 \mathrm{k}$ & $99.2 \mathrm{k}$ & $61.8 \mathrm{k}$ & $4236.0 \mathrm{k}$-in & $7071.3 \mathrm{k}$-in & Elastic & Plastic & $6.22 \mathrm{in}$ \\
\hline $162 \mathrm{k}$ & $99.8 \mathrm{k}$ & $62.2 \mathrm{k}$ & $4280.0 \mathrm{k}$-in & $7071.3 \mathrm{k}$-in & Elastic & Plastic & $6.30 \mathrm{in}$ \\
\hline $163 \mathrm{k}$ & $100.4 \mathrm{k}$ & $62.6 \mathrm{k}$ & $4324.0 \mathrm{k}$-in & $7071.3 \mathrm{k}$-in & Elastic & Plastic & $6.38 \mathrm{in}$ \\
\hline $164 \mathrm{k}$ & $101.0 \mathrm{k}$ & $63.0 \mathrm{k}$ & $4368.0 \mathrm{k}$-in & $7071.3 \mathrm{k}$-in & Elastic & Plastic & $6.46 \mathrm{in}$ \\
\hline $165 \mathrm{k}$ & $101.6 \mathrm{k}$ & $63.4 \mathrm{k}$ & $4412.0 \mathrm{k}$-in & $7071.3 \mathrm{k}$-in & Elastic & Plastic & $6.53 \mathrm{in}$ \\
\hline $166 \mathrm{k}$ & $102.3 \mathrm{k}$ & $63.7 \mathrm{k}$ & $4455.9 \mathrm{k}$-in & $7071.3 \mathrm{k}$-in & Plastic & Plastic & $6.61 \mathrm{in}$ \\
\hline
\end{tabular}

